\title{
Fractures as Preferential Flowpaths for Aquifer Storage and Recovery (ASR) Injections and Withdrawals: Implications for Environmentally Sensitive Near-Shore Waters, Wetlands of the Greater Everglades Basin and the Regional Karst Floridan Aquifer System
}

\author{
Sydney T. Bacchus ${ }^{1}$, Sergio Bernardes ${ }^{2}$, Wenjing $\mathrm{Xu}^{1}$ \& Marguerite Madden ${ }^{1}$ \\ ${ }^{1}$ Center for Geospatial Research, Department of Geography, University of Georgia, Athens, USA \\ ${ }^{2}$ NASA Postdoctoral Program Fellow, Goddard Space Flight Center, Greenbelt, Maryland, USA \\ Correspondence: Marguerite Madden, Center for Geospatial Research, Department of Geography, University of \\ Georgia, Athens, Georgia 30602-2502 USA. E-mail: mmadden@uga.edu
}

Received: March 30, 2015

doi:10.5539/jgg.v7n2p117
Accepted: April 14, 2015

Online Published: May 21, 2015

URL: http://dx.doi.org/10.5539/jgg.v7n2p117

\begin{abstract}
In theory, “aquifer storage and recovery" (ASR) is a form of artificial aquifer recharge consisting of three components: (1) aquifer injections of fluids; (2) withdrawals of the injected fluids; and (3) a period of time between the injections and withdrawals that is considered to be aquifer "storage" of the injected fluids. The injected fluids may be: (1) treated sewage effluent (also known as reclaimed, reuse, or bright water); (2) stormwater runoff pumped out of canals, mine pits or other areas; (3) surface waters from natural lakes and streams; or (4) ground water from different aquifer zones. An evaluation of existing data from more than 80 injection/withdrawal cycle tests at 18 ASR sites in 9 counties throughout southern Florida, in the regional karst Floridan aquifer system of the United States (US) revealed that less than $25 \%$ actual "recovery" was achieved from ASR wells where water from various sources was injected into the regional karst aquifer system. Determination of actual "recovery" was based on the reported chloride content of injected and recovered water and was more suggestive of fluid disposal than aquifer "recharge." Actual "recovery" for those ASR tests, adjusted to the chloride concentrations of injected fluids, ranged from 0-17\% for "storage" periods that ranged from 0-181 days. Although results of actual "recovery" provide little support for the concept of "stored” water, in reality those results also over-estimate the volume of injected water that is stored because it assumes that water recovered at the same chloride concentration is the same water that was injected. There is no evidence in the ASR data to support that assumption. The low actual "recovery" rates occurred despite the fact that 28 of the cycle tests had a "storage" period $\leq 1$ day and the longest "storage" period tested did not exceed 181 days. Those brief "storage" periods also were insufficient to meet the stated agency objectives of retrieving the injected fluids during the dry season, more than six months after injection of what is termed "excess water" during the rainy season. Despite those results, the agency’s Final Technical Data Report (TDR) and groundwater model released in 2014 concluded that: (1) "recovery" from those wells would range from 70-100\% and (2) 232 ASR wells (94 in the upper Floridan aquifer, 37 in the Avon Park Permeable Zone of the middle Florida aquifer and 101 in the Boulder Zone) could be completed in Florida’s Greater Everglades Basin (basin) as restoration. That Final TDR did not consider differences in chloride content between water that was injected into and withdrawn from the ASR cycle tests and that groundwater model for the basin did not include the anisotropy option or preferential flow through karst conduits such as fractures. Preferential flow of water injected and withdrawn could result in both low ASR "recovery" rates and environmental harm, such as submarine groundwater discharge (SGD) contaminated with pollutants, including nutrients that result in harmful algal blooms (HABs). That TDR and groundwater model for southern Florida also did not evaluate the direct, indirect or cumulative adverse impacts of preferential flow from ASR injections and withdrawals (e.g., through fractures) on federally threatened and endangered species, environmentally sensitive areas or on sinkhole formation. Our evaluation of the basin vicinity also included analyses of fracture frequency, length and proximity to ASR wells, other injection and withdrawal wells and modern sinkholes, based on georeferenced and transformed lineaments from three independent sources: the US Army Corps of Engineers (ACOE, 2004c), Florida Department of Transportation (FDOT, 1973), and Vernon (1951). Based on the three lineament data sets included in our study, including
\end{abstract}


fractures that extend for considerable distances through environmentally sensitive areas in the basin such as the Big Cypress National Preserve, Biscayne National Park, Estero Bay, Everglades National Park, Florida Keys National Marine Sanctuary, Indian River Lagoon and Marquesas Keys Wildlife Management Area. Some of these fractures also extend beyond the boundaries of the basin.

Keywords: carbonate aquifer system, coral reefs, eutrophication, geographic information system (GIS), harmful algal blooms (HABs), submarine groundwater discharge (SGD)

\section{Introduction}

\subsection{Terminology Related to Aquifer Storage and Recovery (ASR)}

Terminology related to "aquifer storage and recovery" (ASR) that is used by regulatory agencies, municipalities and representatives of the ASR industry often does not conform with standard or scientific definitions of those terms. That is the case with ASR terminology associated with aquifer injections and withdrawals referenced as ASR that are proposed as components of Everglades restoration in the southeastern United States (US) proposed by the US Army Corps of Engineers (ACOE, 2004a; 2004b; 2014). Examples of such terms include "aquifer storage and recovery," "bubble,” “confining,” "excess water," “feasibility,” "lost to tide,” "performance," "recharge,” "recovery,” "reservoir," "restoration,” "target storage volume” (TSV) and "water banking.”

Therefore, terms that are used in an unorthodox manner in regulatory and other documents referenced in this paper are provided in quotations marks, to avoid confusion and misrepresentation. Table 1 includes descriptions and definitions related to ASR in the Floridan aquifer system from scientific and other sources. Definitions or descriptions of none of the terms listed above, as applied to ASR were included in the dictionaries or glossaries such as those published by the American Geological Institute (AGI), the US Geological Survey (USGS), or similar peer-reviewed publications of geologic and hydrological terms identified for this study (Bates \& Jackson, 1984; Fetter, 1988; Ford \& Williams, 1989; Freeze \& Cherry, 1979; Neuendorf, 2005; US Committee on Redefinition of Ground-Water Terms (US Committee on Ground-Water Terms), 1988). Because of those constraints, documents produced by representatives of the ASR industry are the default sources for definitions and descriptions of terms such as "aquifer storage and recovery," "target storage volume" and "water banking" (Table 1).

\subsection{The Theory of ASR}

Theoretically, ASR is a form of temporary artificial aquifer "recharge" that consists of three components: aquifer injections of fluids "recharge," withdrawals of the injected fluids ("recovery") and a period of time ("cycle") between the injections and withdrawals. That intervening period of time is considered to be "storage" of the injected fluids. The reported strategy of ASR is to "store" the "excess water" in the aquifer during the wet season and then "recover" that water during the dry season when it is needed (Reese, 2002). In reality, there is no "excess" water in southern Florida or any other vicinity of the regional Floridan aquifer system. Stormwater runoff commonly is referenced as "excess water" although that water previously infiltrated as natural recharge for the aquifer system before being converted to "runoff” by increased impervious surfaces. "Excess water" and "lost to tide" terms also ignore the beneficial/essential roles of natural pulses of uncontaminated, nonsaline surface and ground water to coastal ecosystems.

The referenced "excess water" to be injected into the aquifer as artificial "recharge" is one or a combination of the following: (1) stormwater runoff (containing agricultural, industrial and/or municipal contaminants) pumped out of canals, mine pits or other areas; (2) treated sewage effluent (also known as reclaimed water, reuse water, bright water) previously mined from the aquifer system and resulting in induced (forced) recharge; (3) surface water diverted or extracted from natural streams, lakes and other surfacewater ecosystems during the wet season; and (4) ground water withdrawn from one layer or zone of the aquifer system and injected into another (e.g., "augmentation" of depleted nonsaline aquifer zones with water from brackish aquifer zones or injection of surficial aquifer water into the Floridan aquifer, both now referenced as "blending"). Examples of the types of water considered as "excess water" for injection into ASR wells in Florida are included in Figure 1A. Figures 1A and B were created by the Florida Department of Environmental Protection (FDEP) as unpublished agency documents in 2003. Fernald and Purdum (1998) describes how the Floridan aquifer system functions, contradicting concepts in documents promoting ASR (e.g., ACOE, 2014).

Surface discharges of stormwater runoff and sewage effluent have resulted in widespread contamination of surface waters, particularly coastal waters. Aquifer injections, including ASR injections, are viewed as a means of diverting these contaminants from surface waters, without implementing costly contaminant removal processes or less costly alternatives such as mandatory water conservation. Bacchus (2001; 2002) and Bacchus, Bernardes, Jordan and Madden (2014) provide detailed discussions of the continued contamination of surface 
waters from subsurface discharges, such as submarine groundwater discharge (SGD) resulting from aquifer injections in southern Florida and provide evidence of preferential flow of these injected fluids through fractures and subsequent discharge in near-shore coastal waters. Those discussions include a 1995 hypothesis by Bacchus (2002) that preferential (localized) deep-aquifer discharge occurs in the Marquesas Keys, in north Florida Bay areas where seagrass dieoff was reported in 1987 and in areas of coral decline.

Although artificial aquifer "recharge" in the form of aquifer injections theoretically has been occurring for more than 20 years in southern Florida (Merritt et al., 1983), no attempt has been made to conduct a comprehensive scientific analysis of the direct, indirect and cumulative impacts of the aquifer injections and withdrawals associated with ASR in Florida. The US Environmental Protection Agency (USEPA) regulates those types of underground injections pursuant to the federal Safe Drinking Water Act (SDWA) Underground Injection Control (UIC) Program. Because aquifer injections are regulated under the SDWA, the concern of the regulatory, funding and reviewing agencies has been in preventing contamination of underground sources of drinking water (USDW), based on related agency-sponsored events (USGS, 2002).

\begin{tabular}{|c|c|c|}
\hline Term & Source & Description/Definition \\
\hline ASR & Pyne $(2005)^{*}$ & $\begin{array}{l}\text { Aquifer Storage Recovery may be defined as the storage of water in a suitable aquifer } \\
\text { through a well during times when water is available, and recovery of the water from the } \\
\text { same well during times when it is needed. }\end{array}$ \\
\hline Fault & $\begin{array}{l}\text { Bates and } \\
\text { Jackson(1984) }\end{array}$ & $\begin{array}{l}\text { A fracture or fracture zone along which there has been displacement of the sides relative } \\
\text { to one another parallel to the fracture. }\end{array}$ \\
\hline Fracture & $\begin{array}{l}\text { US Committee } \\
\text { on Ground- } \\
\text { Water Terms } \\
(2005)\end{array}$ & $\begin{array}{l}\text { (struc geol) (a) A general term for any surface within a material across which there is no } \\
\text { cohesion, e.g. a crack. Fracture includes cracks, joints, and faults. (b) A crack in a rock } \\
\text { where the movement of rock separated by the crack is normal to the surface. See also: } \\
\text { extension fracture; extension vein; stylolitic fracture. }\end{array}$ \\
\hline Fracture trace & Fetter (1988) & $\begin{array}{l}\text { The surface representation of a fracture zone. It may be a characteristic line of } \\
\text { vegetation of linear soil-moisture pattern or a topographic sag. }\end{array}$ \\
\hline Fracture trace & $\begin{array}{l}\text { Stewart and } \\
\text { Stedje }(1990)\end{array}$ & $\begin{array}{l}\text { Fracture traces are vertical zones of generally higher hydraulic conductivity that can be } \\
\text { vertical pathways for ground-water flow between the surficial and semi-confined } \\
\text { aquifers. }\end{array}$ \\
\hline \multirow[t]{2}{*}{ Georectification } & EsriGIS & See Also : control point, georeferencing, orthorectification \\
\hline & $\begin{array}{l}\text { Dictionary } \\
(2012)\end{array}$ & $\begin{array}{l}\text { 1. [data editing] The digital alignment of a satellite or aerial image with a map of the } \\
\text { same area. In georectification, a number of corresponding control points, such as street } \\
\text { intersections, are marked on both the image and the map. These locations become } \\
\text { reference points in the subsequent processing of the image. }\end{array}$ \\
\hline $\begin{array}{l}\text { Hydraulic } \\
\text { fracturing } \\
\text { (aka fracking) }\end{array}$ & USEPA (2015) & $\begin{array}{l}\text { Hydraulic fracturing is a well stimulation process used to maximize the extraction of } \\
\text { underground resources; including oil, natural gas, geothermal energy, and even water. }\end{array}$ \\
\hline Hydroperiod & $\begin{array}{l}\text { Bacchus } \\
(1998)\end{array}$ & $\begin{array}{l}\text { Three important aspects of a wetland hydroperiod are (1) the depth or stage of } \\
\text { fluctuating ground and surface water; (2) the duration of the water level at a given depth } \\
\text { or stage; and (3) the periodicity or seasonality of the water level fluctuations. Disruption } \\
\text { of any one of these three aspects can lead to the degradation and ultimate destruction of } \\
\text { the wetland and the biota it supports. }\end{array}$ \\
\hline Lineament & $\begin{array}{l}\text { Hobbs } \\
(1904)\end{array}$ & $\begin{array}{l}\text { Significant lines of landscape which reveal the hidden architecture of the rock basement } \\
\text { - a mappable, simple or composite linear feature of a surface, whose parts are aligned in } \\
\text { a rectilinear or slightly curvilinear relationship and which differs distinctly from the } \\
\text { patterns of adjacent features and presumably reflects a subsurface phenomenon. Many } \\
\text { lineaments are identical with seismotectoinic [sic] lines and they therefore afford a } \\
\text { means of to some extent determining in advance the lines of greatest danger from } \\
\text { earthquake shock. }\end{array}$ \\
\hline Lineament & $\begin{array}{l}\text { O'Leary, } \\
\text { Friedman, } \\
\text { and Pohn } \\
\text { (1976) }\end{array}$ & $\begin{array}{l}\text { L. linea }=\text { line }+\mathrm{L} \text {. mentum = akin to; hence, akin to or like a line. A lineament is a } \\
\text { mappable, simple or composite linear feature of a surface, whose parts are aligned in a } \\
\text { rectilinear or slightly curvilinear relationship and which differs distinctly from the } \\
\text { patterns of adjacent features and presumably reflects a subsurface phenomenon. At } \\
\text { largest scale, lineaments may be identified with a single map unit, at smallest scale, they } \\
\text { are expressions of a landscape and may be continental in extent. Hence actual length is } \\
\text { relative to the scale of observation and cannot be arbitrarily limited. Lineaments (1) } \\
\text { have geomorphic expression (in general, topographically negative), (2) are composite } \\
\text { (either segmented or complex), (3) are characterized by alignment in a single direction } \\
\text { (which may or may not conform to regional trend), (4) are straight or slightly curved, (5) } \\
\text { are regional in extent, and }(6) \text { are scale related. }\end{array}$ \\
\hline Sinkhole & $\begin{array}{l}\text { US Committee } \\
\text { on Ground- } \\
\text { Water Terms } \\
(2005)\end{array}$ & $\begin{array}{l}\text { A closed depression in a karst or pseudokarst area, commonly with a circular or } \\
\text { ellipsoidal pattern. It's [sic] drainage is subterranean; it's [sic] size is measured in meters } \\
\text { or tens of meters; and it is commonly fumnel shaped. Syn doline; sink (karst); } \\
\text { shakehole. Cf collapse sinkhole; solution sinkhole. }\end{array}$ \\
\hline $\begin{array}{l}\text { Target Storage } \\
\text { Volume } \\
\text { (aka Water } \\
\text { banking) }\end{array}$ & $\begin{array}{l}\text { CH2MHill } \\
(2002)^{*}\end{array}$ & $\begin{array}{l}\text { The sum of the stored water volume required to meet a predetermined recovery volume } \\
\text { goal, plus the volume of water in a freshwater buffer zone surrounding the stored water } \\
\text { volume. At such time as this TSV may be achieved in each well, it should be possible to } \\
\text { achieve } 100 \text { percent recovery efficiency for all subsequent water stored and recovered in } \\
\text { that well to meet the targeted recovery volume. }\end{array}$ \\
\hline
\end{tabular}


Locations of the 52 wells in Florida intended for temporary artificial aquifer "recharge" through 2003, at the approximate time of the initial ASR investigations, primarily were concentrated near the coast, as shown in Figure 1A. Another form of artificial aquifer "recharge" in Florida occurs through Class I injection wells for the stated purpose of contaminated fluid disposal. Those fluids are not injected with the intent of "recovery." Information available from the FDEP web site (http://www.dep.state.fl.us/water/uic/index.htm) in August 2005 indicated that more than 125 Class I injection wells injecting approximately "361 million gallons per day" (MGD) reportedly were active in Florida. The map that showed the distribution of those Class I wells included the locations of only 102 Class I aquifer injection wells (Figure 1B). More than 1,000 additional underground injection sites for minimally treated sewage effluent have been permitted in Monroe County alone, the most southern county in Florida, but no map was available for those locations from FDEP at that time. The current FDEP database does not include the volume of injected fluids for each well to enable a determination of the total daily permitted volume of injected fluids.

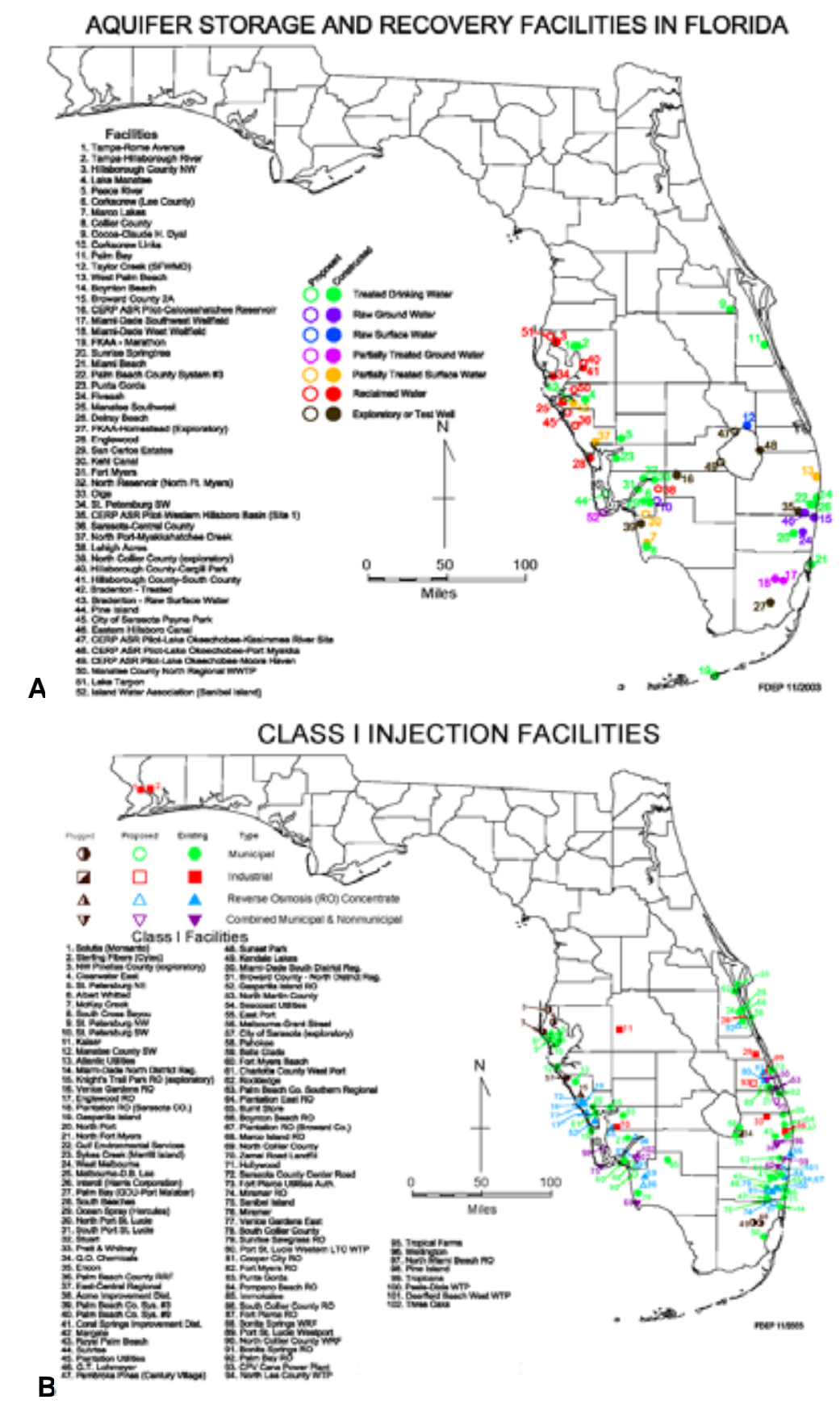

Figure 1. November 2003 locations of Florida's aquifer-injection wells intended for A. aquifer storage and recovery (Class V) and B. disposal (Class I) 


\subsection{Objectives}

There were multiple objectives of our scientific review and analysis. The first objective was to evaluate published literature and agency documents related to "storage" and "recovery" of water injected into ASR wells. The second objective was to evaluate published literature and agency documents related to factors, such as fractures, that could result in preferential flow of ASR injections and withdrawals. The final objective was to consider various adverse environmental impacts that can be associated with these types of aquifer injections and implications of these adverse impacts for the Everglades restoration effort. The provisions of the National Environmental Policy Act (NEPA), the Clean Water Act (CWA), and the Endangered Species Act (ESA), rather than the SDWA, were the focus of our review and analysis. Our evaluation of the basin includes analyses of the proximity of ASR wells and other injection and withdrawal wells to georeferenced and transformed lineaments representing fractures from three independent sources (ACOE, 2004c; FDOT, 1973; Vernon, 1951) as an explanation for the low actual "recovery" from ASR cycle tests and adverse environmental impacts.

\section{Study Area}

Our case study was the vicinity of the Greater Everglades Basin (basin), located in southern Florida, where extensive aquifer injections are occurring. The ten counties entirely within the boundaries of the basin include: Broward, Collier, Dade, Glades, Hendry, Lee, Martin, Monroe, Palm Beach and St. Lucie. The eight additional counties partially within the boundaries of the basin include: Charlotte, DeSoto, Highlands, Lake, Okeechobee, Orange, Osceola and Polk. Figure 2 shows the area of the case study, including the locations of the counties, boundaries of the basin, boundaries of the 12 sub-basins within in the Greater Everlades Basin and the surrounding coastal waters.

The study area, located in the south Florida sub-region of the regional Floridan aquifer system, includes bedding planes, fractures, dissolution cavities, and other karst features which extend to the submerged carbonate platform (Popenoe, Kohout \& Manheim, 1984), as summarized in Bacchus et al. (2014). The earliest record of aquifer injections in FDEP's spreadsheet database was 1957, but only 308 of the more than 1400 Class V aquifer-injection wells recorded in that database included any dates related to permitting or operation of those wells.

The study area includes environmentally sensitive areas such as Bahia Honda State Park; Big Cypress National Preserve (BCNP, Figure 2B); Biscayne Bay and Card Sound Aquatic Preserves; Biscayne National Park; Coupon Bight Aquatic Preserve; Crocodile Lake National Wildlife Refuge; Dry Tortugas National Park; Estero Bay; Everglades National Park (ENP, Figure 2B); Florida Keys National Marine Sanctuary (FKNMS, incorporating John Pennekamp Coral Reef State Park and the Key Largo and Looe Key National Marine Sanctuaries); Fort Zachary Taylor National Marine Sanctuary; Great White Heron National Wildlife Refuge; Indian River Lagoon; Key Largo Hammocks Botanical Site; Key West National Wildlife Refuge; Lignumvitae Aquatic Preserve; Lignumvitae Key State Botanical Site; Marquesas Keys Wildlife Management Area; National Key Deer Refuge; Shell Key Sate Preserve; and San Pedro State Underwater Archeological Site.

A

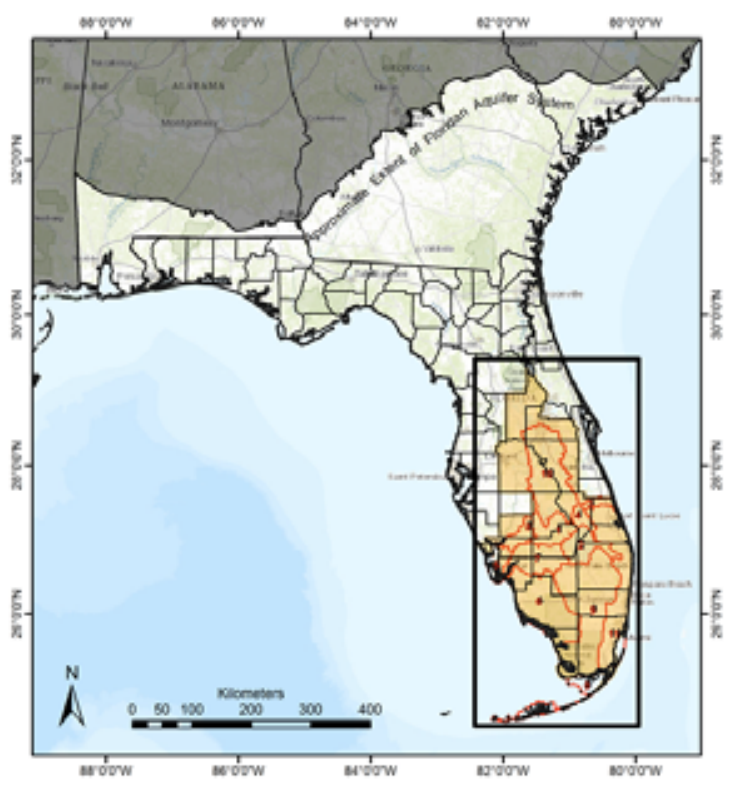




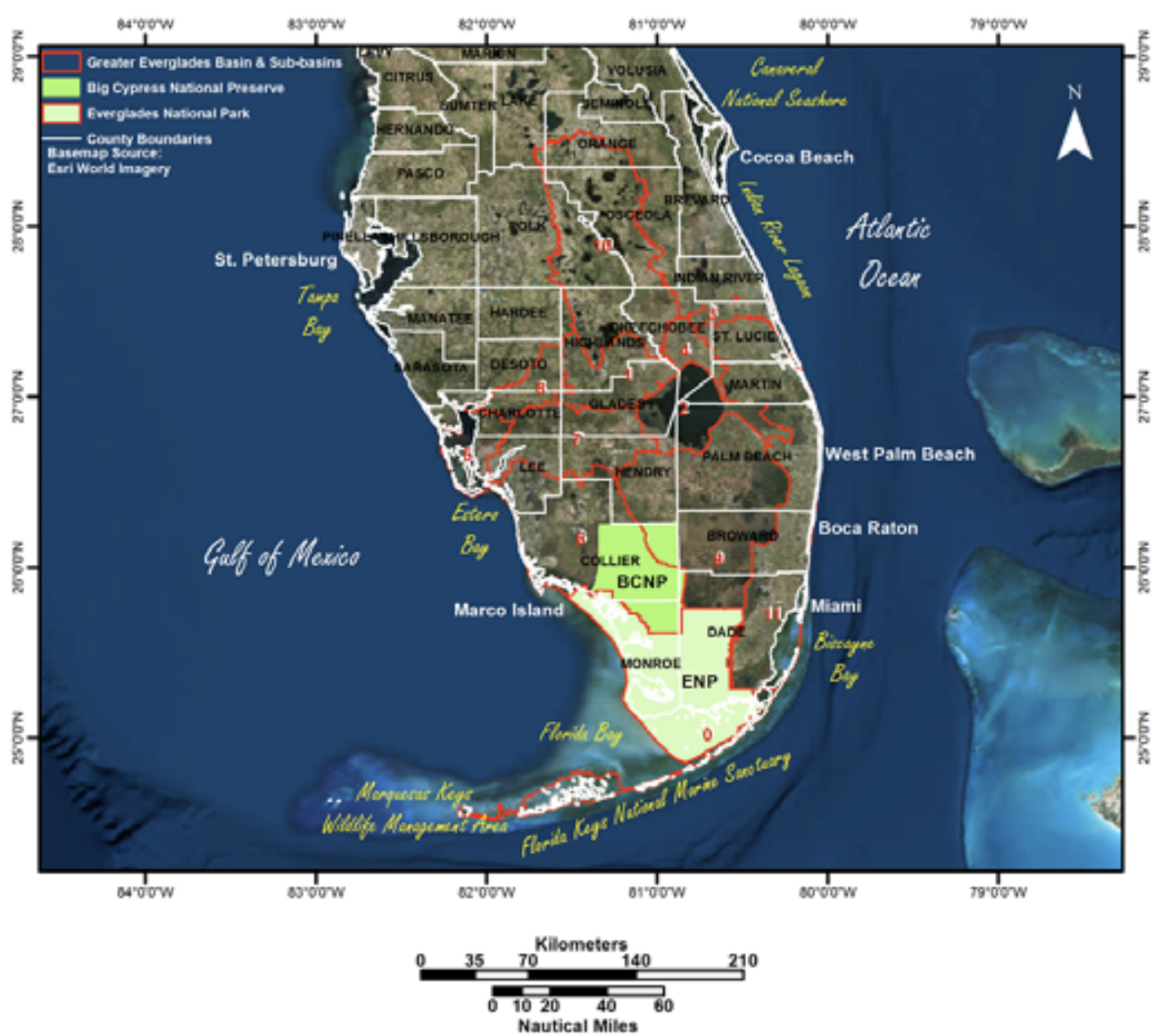

Figure 2. A. Location of the study area in the southern Florida sub-region of the regional Floridan aquifer system, with 10 counties entirely within the boundaries of the Greater Everglades Basin and 8 counties partially within the boundaries of the basin and B. more detailed view showing Big Cypress National Preserve (BCNP) and Lake

Okeechobee (at \#2) and surrounding coastal waters of the Atlantic Ocean, Biscayne Bay, Canaveral National Seashore, Estero Bay, Everglades National Park (ENP), Florida Bay, Florida Keys National Marine Sanctuary, Gulf of Mexico, Indian River Lagoon, Marquesas Keys Wildlife Management Area and Tampa Bay.

Table 2. Names and number of fractures in the 12 sub-basins of the Greater Everglades Basin

\begin{tabular}{cllcc}
\hline ID & \multicolumn{1}{c}{ Name (Alias) } & Vernon & $\begin{array}{c}\text { Fractures } \\
\text { FDOT }\end{array}$ & ACOE \\
\hline 0 & Florida Bay/Keys (Florida Bay \& Keys) & 0 & 9 & 0 \\
1 & Western Okeechobee Inflow (Western Lake Okeechobee) & 0 & 53 & 69 \\
2 & Lake Okeechobee (same) & 0 & 35 & 23 \\
3 & Indian River Lagoon(Vero Beach) & 5 & 21 & 14 \\
4 & Taylor CreekNubbin Slough(Northern Okeechobee Inflow) & 0 & 25 & 37 \\
5 & Charlotte Harbor (Charlotte) & 0 & 18 & 12 \\
6 & Big Cypress Swamp (same) & 0 & 63 & 73 \\
7 & Caloosahatchee (Caloosahatchee River) & 0 & 68 & 90 \\
8 & Peace (Peace River) & 0 & 45 & 54 \\
9 & Everglades (Everglades National Park) & 0 & 87 & 82 \\
10 & Kissimmee Basin(Kissimmee River) & 59 & 161 & 66 \\
11 & Florida East Coast (Southeast Coast) & 0 & 66 & 72 \\
\hline
\end{tabular}




\section{Methods}

\subsection{Agency Shapefiles, Data and Analog to Digital Conversion of Lineaments Representing Fractures}

The locations for the basin and sub-basins, Big Cypress National Preserve (BCNP), Everglades National Park (ENP) and groundwater withdrawal wells permitted by the SFWMD were created from shapefiles obtained from that agency. The locations for groundwater withdrawal wells permitted by the SWFWMD and the SJRWMD were created from shapefiles obtained from those agencies, respectively. The locations for the aquifer-injection wells permitted by the FDEP, including the ASR wells, were created from location information included in the FDEP database and provided by that agency. The locations for sinkholes were created from the FDEP Florida Geological Survey (FGS) shapefile for subsidence features mapped in Florida through October 2014 and the term sinkhole is used synonymously with subsidence. Data for examples of federally endangered and threatened species were obtained from the US Fish and Wildlife Service and the listing status was reverifed on on May 18, 2015 (USFWS, 2015). Data for examples of state endangered and threatened species and species of special concern were obtained from the Florida Natural Areas Inventory and were reverified on May 19, 2015 (Kimberely Gulledge, FNAI, pers. comm., 5/19/15).

Shapefiles could not be obtained from the ACOE for the lineaments shown as the "Lineament map of south Florida" in Figure 3-7 of the 2014 ACOE report (ACOE, 2014, originally from ACOE, 2004c). Therefore, a digital file of those lineaments was created by converting the original report figure from the portable document format (PDF) to a drawing exchange format (DXF). The DXF file then was imported into ArcGIS and 28 control points distributed throughout the figure were identified over the region defined by the boundaries of the lineament data. Control point identification used a county layer and a boundary layer for the state of Florida as reference because the original report figure included county and state boundaries. Following control point identification and analysis (RMS Error: 0.0062) an affine transformation was used to assign real-world coordinates to the lineament data in vector format. Distribution of the control points is shown in Figure 3. The acquisition methods for the FDOT (1973) and Vernon (1951) lineaments were described in Bacchus et al. (2014) and Lines et al. (2012).

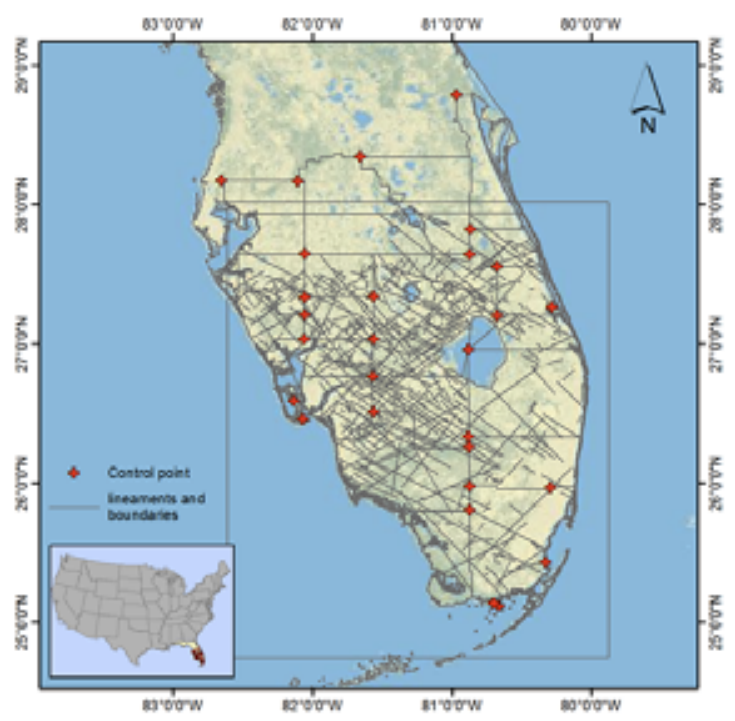

Figure 3. Locations of 28 control points acquired over south Florida for georeferencing the ACOE (2004c) analog lineaments map displayed in Figure 3-7 of the ACOE Final TDR (2014)

\subsection{ASR Database for Florida}

Initial attempts by the senior author to conduct an independent scientific review of ASR and other aquifer injections and the associated adverse environmental impacts of those injections in Florida were delayed for more than five years because much of the information regarding aquifer injections in Florida is unpublished or contained in grey literature and extremely difficult to obtain. Even when such unpublished literature was part of the public record of agencies that are permitting, funding, evaluating and/or engaged in aquifer injections in Florida, many of the documents that were requested to conduct a thorough review of aquifer injections could not be obtained after months or years following the initial requests. Repeated attempts to obtain copies of selected ASR and other aquifer injection permits and related documents often resulted in no response from the agencies, 
even when formal records requests were made for public documents. Those efforts also were hindered by the fact that regulatory agencies provided only limited data related to ASR wells, such as the maps provided by FDEP in Figure 1. Additionally, there was no comprehensive map, database or list of all ASR locations in conjunction with a comprehensive depiction of all other aquifer injections in Florida under the authority of federal, state or county agencies (Joan Harrigan-Farrelly, USEPA; Richard Deuerling, FDEP; and Mark Hooks, Florida Department of Health (DOH), pers. comm.).

Those problems extended to standard federal publications addressing aquifer injections, such as Water-Resources Investigations Reports published by the USGS and copies of permits for aquifer injections. For example, a copy of the inventory and review of ASR in southern Florida (Reese, 2002) was requested soon after it was published by the USGS. In response to that request, the USGS indicated that their agency had been instructed by unnamed sources in Washington, DC not to release the report to the public because of purported national security reasons (Patsy Mixson, USGS, pers. comm.). After months of similar requests at different levels, a copy of the report finally was obtained from USGS, with the assistance of the Legal Environmental Assistance Foundation (LEAF). Copies of aquifer injection permits that were obtained revealed that no requirements or conditions were included for monitoring to detect contamination of surface waters (including wetlands) resulting from those aquifer injections. Likewise, no conditions are included that would require monitoring or other assessments of the impacts of aquifer injections on fish and wildlife, particularly threatened and endangered species. These inadequacies appear to have persisted in the most recent government and institute publications proposing large-scale construction of new ASR wells in the Greater Everglades Basin (ACOE, 2014; Graham et al., 2015), although locations of injection wells now are available on line (http://ca.dep.state.fl.us/mapdirect/?focus=uic).

\subsection{Data Analysis}

Actual "recovery" was determined by adjusting the results of cycle testing conducted in ASR test wells constructed in south Florida to compensate for differences between chloride concentration of water injected into ASR wells and water withdrawn from those wells (=reported chloride concentration/(recovered/injected concentration)). Spatial frequency analysis of previously mapped linear features indicative of fractures in the vicinity of the basin was conducted by creating rose diagrams similar to those created by Brook and Allison (1986) and Harnett and Barnett (1977) and using the description of length-weighted rose diagrams provided by Prost (2002). The angular distribution of cumulative lengths was computed for the basin and for each sub-basin. The length-weighted rose diagrams did not clip lineaments at those boundaries because the objective was to show the total lineament length and potential groundwater connectivity through the fractures. Therefore, the total lengths of lineaments within the basin and sub-basin boundaries were used in calculations, including parts of those lineaments that extended beyond the basin and sub-basin boundaries. Individual rose diagrams were generated for the sub-basins and basin (center= $0 \mathrm{~km}$, outer circle=5,000 km and step=1,000 km) .

Geospatial analysis to assess fracture lineaments, sinkholes and wells was conducted in ArcGIS Version 10.2, as GIS is an established aid in visualizing and mapping rock properties in regions of subtle topography (Belt \& Paxton, 2005). The data layers for sinkholes and fractures were reconciled to a common, Robinson projection system. This pseudocylindrical projection has minimal distortions within areas approximately $45^{\circ}$ north and south of the equator. The study area is located between $20^{\circ} \mathrm{N}$ and $30^{\circ} \mathrm{N}$ latitude, respectively. The Robinson Projection is known as a compromise projection that maintains all types of distortions to be relatively low over most of the globe (Usery, Finn \& Mugnier, 2009; Dean, 2012). The spatial join tool of ArcGIS was used to join the attributes of the two feature classes using the spatial relationship, "CLOSEST." The result was a list of distances to fracture lineaments from which the shortest distances were selected.

\section{Results}

\subsection{Reported "Recovery" vs. Actual "Recovery" Based on Adjustment of Chloride Concentrations}

Table 3 summarizes available information from more than 80 cycle tests (injections, "storage" and subsequent withdrawals) that utility departments and consultants conducted and recorded between 1980 and 2000. Those data were reviewed by USGS (Reese, 2002) and three of the cycle tests (all at a single well) were conducted by the USGS at a single site (Lake Okeechobee/Taylor Creek/Nubbin Slough) in the northern vicinity of the Everglades restoration project. That area is the focus of one of the primary Comprehensive Everglades Restoration Plan (CERP) “ASR pilot projects” for proposed aquifer injections and withdrawals in the Everglades basin. The USGS report includes maps showing the locations of those sites (Reese, 2002), presumably also included in Figure 1A, which reportedly depicts all injection wells permitted by FDEP through 2003. 
Table 3. Comparison of chloride concentration in injected and "recovered" fluids, reported "recovery," and actual "recovery" for ASR wells inventoried by USGS in southern Florida. "Recovered" concentrations more than twice injected concentrations are shown in bold ( $\mid$ all data except actual recovery efficiency from Reese, 2002, Table 5).

\begin{tabular}{|c|c|c|c|c|c|c|c|}
\hline $\begin{array}{l}\text { Site Name/ } \\
\text { Site Number }\end{array}$ & $\begin{array}{c}\text { Cycle } \\
\text { No. }\end{array}$ & $\begin{array}{c}\text { Ambient } \\
\text { Chloride } \\
\text { Conc. } \\
\text { (mg/L) }\end{array}$ & $\begin{array}{c}\text { Injected } \\
\text { Chloride } \\
\text { Conc. } \\
\text { (mg/L) }\end{array}$ & $\begin{array}{c}\text { Recovered } \\
\text { Chloride } \\
\text { Conc. } \\
\text { (mg/L) }\end{array}$ & $\begin{array}{l}\text { Reported } \\
\text { Recovery } \\
\text { Efficiency } \\
\text { (percent) }\end{array}$ & $\begin{array}{c}\text { Actual } \\
\text { Recovery } \\
\text { Efficiency } \\
\text { (percent) }\end{array}$ & $\begin{array}{l}\text { Storage } \\
\text { Period } \\
\text { (days) } \\
\end{array}$ \\
\hline \multicolumn{8}{|c|}{ Broward County } \\
\hline Broward & Test & 2,000 & 30 & 225 & $>20$ & 2.7 & 1 \\
\hline \multirow[t]{2}{*}{ (2) } & 1 & 2,000 & 35 & 225 & $>21$ & 3.3 & 0 \\
\hline & 2 & 2,000 & 35 & 225 & $>26$ & 4.0 & 9 \\
\hline Springtree $^{1}$ & 1 & 3,600 & 70 & 61 & $>20$ & $\mathrm{NC}$ & 0 \\
\hline \multirow[t]{4}{*}{ (3) } & 2 & 3,600 & 65 & 213 & $>28$ & 8.5 & 1 \\
\hline & 3 & 3,600 & 60 & 225 & $>38$ & 10.1 & 1 \\
\hline & $4^{*}$ & 3,600 & 60 & 222 & $>38$ & 10.1 & 32 \\
\hline & $5^{*}$ & 3,600 & NR & 225 & $>28$ & 7.3 & 31 \\
\hline Fiveash & $1^{*}$ & 3,520 & 60 & 225 & $>11$ & 2.9 & 0 \\
\hline (4) & $2^{*}$ & 3,520 & 59 & 225 & $>6$ & 1.6 & 1 \\
\hline \multicolumn{8}{|c|}{ Charlotte County } \\
\hline Shell Creek & 1 & 830 & 100 & 250 & 30 & 12.0 & 0 \\
\hline \multirow[t]{3}{*}{ (5) } & 2 & 830 & 75 & 250 & 37 & 11.1 & 0 \\
\hline & 3 & 830 & $180-230$ & 250 & 9 & 7.4 & 1 \\
\hline & 3 & 830 & $80^{2}$ & 250 & $15^{2}$ & 4.8 & 1 \\
\hline \multicolumn{8}{|c|}{ Collier County } \\
\hline Manatee Rd. & 1 & 2,750 & 60 & 300 & NR & NR & 6 \\
\hline \multirow[t]{3}{*}{ (7) } & 2 & 2,750 & 60 & 300 & 7 & 1.4 & 19 \\
\hline & 3 & 2,750 & 60 & 300 & 24 & 4.8 & 20 \\
\hline & 4 & 2,750 & 60 & 300 & 32 & 6.4 & 20 \\
\hline Marco Lakes & $1^{*}$ & 2,600 & $110^{*}$ & 384 & 22 & 6.4 & 3 \\
\hline \multirow[t]{4}{*}{ (8) } & $2^{*}$ & 2,600 & $115^{*}$ & 398 & 4 & 1.2 & 63 \\
\hline & $3^{*}$ & 2,600 & $130^{*}$ & 370 & 33 & 11.7 & 2 \\
\hline & $4^{*}$ & 2,600 & $130^{*}$ & 420 & NR & NR & 98 \\
\hline & $5^{*}$ & 2,600 & $110^{*}$ & 395 & NR & NR & 109 \\
\hline \multicolumn{8}{|c|}{ Lee County } \\
\hline \multirow{3}{*}{$\begin{array}{c}\text { Lee County } \\
\text { (9) }\end{array}$} & 1 & 550 & 60 & 250 & 39 & 9.3 & 0 \\
\hline & 2 & 550 & $150-350$ & 250 & 10 & 9.7 & 47 \\
\hline & 3 & 550 & $60-100$ & 250 & 30 & 9.7 & 98 \\
\hline \multirow{3}{*}{$\begin{array}{c}\text { Corkscrew } \\
(10)\end{array}$} & 1 & 39 & NR & $\mathrm{DS}=330$ & NR & NR & 1 \\
\hline & 2 & 39 & NR & $\mathrm{DS}=300$ & NR & NR & 35 \\
\hline & 3 & 39 & NR & $\mathrm{DS}=225$ & NR & NR & 31 \\
\hline $\begin{array}{c}\text { N. Reservoir } \\
\text { (11) }\end{array}$ & $1^{*}$ & 670 & 155 & 250 & 10 & 6.1 & 7 \\
\hline \multirow{2}{*}{$\begin{array}{l}\text { San Carlos } \\
\text { (13) }\end{array}$} & Test & 1,150 & 90 & 600 & 2 & 0.3 & 6 \\
\hline & 1 & 1,150 & 90 & 466 & 3 & 0.6 & 0 \\
\hline \multicolumn{8}{|c|}{ Miami-Dade County } \\
\hline \multirow{3}{*}{$\begin{array}{l}\text { Hialeah } \\
\text { (15) }\end{array}$} & 1 & 1,200 & $65^{3}$ & $\mathrm{NR}$ & 33 & 8.6 & 2 \\
\hline & 2 & 1,200 & $65^{3}$ & NR & 48 & 12.4 & 54 \\
\hline & 3 & 1,200 & $65^{3}$ & NR & 39 & 10.0 & 181 \\
\hline \multirow{7}{*}{$\begin{array}{c}\text { W Well Field } \\
(17)\end{array}$} & $1^{*}$ & 2,400 & 48 & 164 & $>8$ & 2.3 & 0 \\
\hline & $2^{*}$ & 2,400 & 48 & 80 & $>25$ & 13.5 & 0 \\
\hline & $2^{*}$ & 2,400 & 43 & 212 & $>22$ & 4.5 & 0 \\
\hline & $3^{*}$ & 2,400 & 41 & 500 & 57 & 4.7 & 18 \\
\hline & $3^{*}$ & 2,400 & 41 & 1,150 & 54 & 1.9 & 123 \\
\hline & $3^{*}$ & 2,400 & 41 & No Recovery & NR & NR & NR \\
\hline & $3^{*}$ & 2,400 & 41 & \#3s combined & $41 \mp$ & 3.9 & NR \\
\hline
\end{tabular}




\begin{tabular}{|c|c|c|c|c|c|c|c|}
\hline \multicolumn{8}{|c|}{ Monroe County } \\
\hline Marathon & 1 & 20,800 & 42 & 16,200 & 33 & 0.1 & $\mathrm{O}$ \\
\hline \multirow[t]{10}{*}{ (19) } & 2 & 20,800 & NR & 290 & 28 & 4.1 & 34 \\
\hline & 3 & 20,800 & NR & NR & 68 & 11.4 & 0 \\
\hline & 4 & 20,800 & NR & NR & 72 & 12.1 & $\mathrm{O}$ \\
\hline & 5 & 20,800 & NR & NR & 43 & 7.2 & 39 \\
\hline & 6 & 20,800 & NR & NR & 51 & 8.6 & 36 \\
\hline & 7 & 20,800 & NR & NR & 55 & 9.2 & 35 \\
\hline & 8 & 20,800 & NR & NR & 65 & 10.9 & 21 \\
\hline & 9 & 20,800 & NR & NR & 65 & 10.9 & 0 \\
\hline & 10 & 20,800 & $\mathrm{NR}$ & NR & 56 & 9.4 & 35 \\
\hline & 11 & 20,800 & $\mathrm{NR}^{4}$ & NR & 71 & 11.9 & 81 \\
\hline \multicolumn{8}{|c|}{ Okeechobee County } \\
\hline Taylor Cr./ & $4^{5}$ & 3,100 & NR & $1,385^{6}$ & NR & NR & $\mathrm{O}$ \\
\hline Nubbin Slgh/ & $1^{7}$ & 3,100 & 150 & $1,385^{6}$ & 3 & 0.3 & $\mathrm{O}$ \\
\hline Lake Okeech. & $2^{7}$ & 3,100 & $100 ?$ & $1,385^{6}$ & 3 & 0.2 & 8 \\
\hline$(20)$ & $3^{7}$ & 3,100 & $70 ?$ & $1,385^{6}$ & 7 & 0.4 & 5 \\
\hline \multicolumn{8}{|c|}{ Palm Beach County } \\
\hline Jupiter & 1 & 1,980 & 65 & 250 & $\mathrm{O}$ & 0.0 & 15 \\
\hline \multirow[t]{3}{*}{ (21) } & 2 & 1,980 & 65 & 250 & 5 & 1.2 & 30 \\
\hline & 3 & 1,980 & 65 & 250 & 18 & 4.7 & 30 \\
\hline & 4 & 1,980 & 65 & 250 & 35 & 9.2 & 120 \\
\hline Boynton Bch & 1 & 1,920 & 60 & 760 & 47 & 3.7 & 0 \\
\hline \multirow[t]{16}{*}{ (22) } & 2 & 1,920 & 50 & 420 & 30 & 3.6 & 0 \\
\hline & 3 & 1,920 & 50 & NR & 47 & NR & 5 \\
\hline & $3^{*}$ & 1,920 & 47 & 300 & 49 & 7.7 & 8 \\
\hline & $4^{*}$ & 1,920 & 51 & 274 & 90 & 16.8 & 8 \\
\hline & $5^{*}$ & 1,920 & 46 & 300 & 54 & 8.2 & 98 \\
\hline & $6^{*}$ & 1,920 & 47 & 306.5 & 64 & 9.8 & 57 \\
\hline & $7 *$ & 1,920 & 48 & 302 & 27 & 4.2 & 24 \\
\hline & $8^{*}$ & 1,920 & 52 & 320.5 & 40 & 6.5 & 2 \\
\hline & $9^{*}$ & 1,920 & 52 & 301 & 63 & 10.9 & 22 \\
\hline & $10^{*}$ & 1,920 & 48 & 307 & 75 & 11.7 & 52 \\
\hline & $11^{*}$ & 1,920 & 41 & 314 & 82 & 10.7 & 149 \\
\hline & $12^{*}$ & 1,920 & 49 & 302 & 66 & 10.7 & 81 \\
\hline & $13^{*}$ & 1,920 & 48 & 317.5 & 70 & 10.6 & 174 \\
\hline & $14^{*}$ & 1,920 & 62 & 1,004 & 81 & 5.0 & 1 \\
\hline & $15^{*}$ & 1,920 & 46 & 146 & $>34$ & 10.7 & 57 \\
\hline & $16^{*}$ & 1,920 & NR & 310 & 84 & 13.5 & 4 \\
\hline \multirow{4}{*}{$\begin{array}{c}\text { W Palm Bch } \\
\text { (24) }\end{array}$} & $1^{*}$ & 2,800 & NR & NR & NR & NR & $\mathrm{O}$ \\
\hline & $2^{*}$ & 2,800 & NR & NR & NR & NR & 1 \\
\hline & $3^{*}$ & 2,800 & NR & NR & NR & NR & 3 \\
\hline & $4^{*}$ & 2,800 & NR & NR & NR & NR & 3 \\
\hline \multicolumn{8}{|c|}{ St. Lucie County } \\
\hline \multirow{2}{*}{$\begin{array}{c}\text { St. Lucie Co. } \\
\text { (27) }\end{array}$} & 1 & 955 & 200 & NR & 3 & NR & 38 \\
\hline & 1 & 955 & $50^{2}$ & NR & 33 & NR & 38 \\
\hline \multicolumn{8}{|c|}{$\begin{array}{l}\text { orted "recovery" adjusted to } 250 \mathrm{mg} / \mathrm{L} \text { chloride level for potable water by Reese, } 2002 \text {; actual "recovery" adjusted } \\
\text { hloride concentration of injected fluids for each cycle test for our study (=reported/(recovered/injected)) } \\
\text { a extracted by USGS from monthly operating reports and daily records provided by the water treatment plant } \\
\text { Recorded; NC Not Calculated (chloride reduced); DS Dissolved Solids recorded instead of chloride concentratic } \\
\text { orted as "100 or less" and "70 or less;" } \$ \text { USGS report combined values for all three No. } 3 \text { ASR wells } \\
\text { le } 5 \text { had } 52 \text { days of down time during the recharge period } \\
\text { overy efficiency estimated using a fictitious value for recharge chloride concentration } \\
\text { overy continued past the reported recovery volume, which had an ending chloride concentration of } 250 \mathrm{mg} / \mathrm{L} \\
\text { additional } 5.2 \text { million gallons were recharged during the last } 57 \text { days of the storage period by trickle flow } \\
\text { aducted by CH2M Hill }\end{array}$} \\
\hline
\end{tabular}

Table 3 includes chloride levels for: (1) the ground water in the aquifer layer receiving the injected fluids (ambient); (2) the injected fluids; and (3) the "recovered" fluids for the cycle tests as reported for the 18 ASR facilities in the nine southern-Florida counties inventoried by USGS (Reese, 2002). The "storage" period for each of the ASR tests (number of days lapsed between the injection and withdrawal of fluids), as reported by USGS, also is provided in Table 3. The reported "recovery" efficiencies for the three ASR cycle tests conducted by USGS were $3.1 \%, 2.7 \%$, and $7.2 \%$ for "storage" periods of 0 , 8 , and 5 days, respectively. Those "recovery" efficiencies were equivalent to the lowest values reported for all of the cycle tests reported in the USGS inventory and review (Table 3). The engineering firm CH2M Hill conducted the initial cycle test at that Lake Okeechobee site, but failed to provide the chloride concentration of the injected canal water (see Table 5 from Reese, 2002). The "recovery" efficiencies reported by USGS were based on the agency's adjustment of results to $250 \mathrm{mg} / \mathrm{L}$. 
Actual "recovery" for our study, based on adjustments for chloride-concentration differences between the injected and "recovered" water from those cycle tests, also are included in Table 3. Actual "recovery" for those cycle tests was considerably less than the reported "recovery" efficiencies evaluated by USGS (Table 3). All but three of the chloride concentrations for the "recovered" fluids are more than twice the chloride concentration of the injected fluids, as shown in bold in Table 3. Examples of the "recovery" graphs from Reese (2002) from the east coast (Boynton Beach East Water Treatment Plant) and the west coast (Marco Lakes) are provided in Figure 4. The lower horizontal lines in those two graphs represent the chloride concentrations of the injected water (fluids) for those ASR wells. The upper horizontal lines in those two graphs represent the chloride concentration of $250 \mathrm{mg} / \mathrm{L}$. The $\mathrm{X}$ axis shows the percent "recovery" and reveals that the chloride concentrations (Y axis) of the "recovered" water rapidly exceeds the chloride concentrations of the injected water in all cycle tests at both sites.

Based on data provided by utility department staff and consultants and reported by USGS ("Reported Recovery" column in Table 5 from Reese, 2002), the reported percentage of "recovered" water for many of the cycle tests is within the range of 30-90\%. By comparing the values for "Reported Recovery" and "Actual Recovery" in Table 3 , however, the ranges of actual "recovery" calculated for the east coast ASR sites inventoried by USGS and rounded to the nearest percent were, by county: Broward - Broward 3-4\%; Springtree 7-10\%; Fiveash 2-3\%; Shell Creek 5-12\%; Manatee Road 1-6\%; Miami-Dade - West Well Field 2-14\%; Monroe - Marathon 0-12\%; Palm Beach - Jupiter 0-9\%; Boynton Beach 4-17\%; West Palm Beach NR (no record of chloride levels) and St. Lucie - St. Lucie NR. Actual "recovery" for the first cycle test at Springtree was not calculated because the chloride concentration of the "recovery" water was lower than the chloride concentration of the injected water after a "storage" period of " 0 " days. Explanations for the reduced chloride content in "recovery" water for cycle 1 could include induced "recharge" of fresh water (lower chloride concentration) from the overlying surficial aquifer at or near the site of that injection well or from a greater distance away from the ASR well via preferential flow (e.g., fracture flow). The Everglades Wildlife Management Area is located to the west of the Springtree ASR well site and the vicinity of that ASR well site includes a myriad stormwater ponds, ditches, canals and channelized areas that previously were natural freshwater wetlands and streams, such as those associated with fractures. The ranges of actual "recovery" calculated for the west coast ASR sites inventoried by USGS were, by county: Collier - Marco Lakes 1-12\% and Lee - Lee 9-10\%; Corkscrew NR; North Reservoir 6\%; San Carlos 0-1\%; Hialeah 9-12\%. The ranges of actual "recovery" calculated for Lake Okeechobee ASR sites inventoried by USGS and located in Okeechobee County (between the east and west coasts), were: Lake Okeechobee/Taylor Creek/Nubbin Slough 0-0\%.

\subsection{Locations and Orientations of Previously Mapped Fractures in the Vicinity of the Greater Everglades Basin}

The locations of fractures previously mapped by Vernon (1951), the Remote Sensing Section of FDOT (1973) and unidentified source(s) originating in an unauthored draft report by ACOE (2004c) and included in the ACOE Final TDR (2014) were incorporated into our ArcGIS database for this case study. This conversion of analog mapped lineaments enabled: (1) comparison of locations of fractures networks that were identified in those three independent sources; (2) calculation of the frequency and lengths of those previously mapped fractures in the vicinity of the basin, sub-basins and counties; (3) analysis of the proximity of those previously mapped fractures to ASR wells, other injection and withdrawal wells, and modern sinkholes. The locations of these three sets of previously mapped fractures are shown in Figure 5. Table 2 includes the number of fractures from each data set that occurs within each sub-basin.

The fractures mapped by Vernon (1951) only extend into the northern vicinity of the basin because the focus of that study was further north. The only counties associated with the basin where the fractures mapped by Vernon (1951) occur include Lake, Okeechobee, Orange, Osceola, Polk and St. Lucie (Figure 5). The fractures originally reported in the draft ACOE report (2004c) are concentrated in the southern vicinity of the basin. That mapping project appears to have excluded the northern portions of Osceola and Polk Counties and all of Lake and Orange Counties (Figure 5). The most extensive fracture network was mapped by FDOT (1973) and covers all counties associated with the Greater basin and the entire State of Florida. The absence of lineaments representing fractures in the center of south Florida coincides with the location of Lake Okeechobee and results from the inability to detect those linear features across water bodies with the aerial photography and satellite images used for those three data sets. Therefore, the absence of mapped lineaments in that area of Figure 5 does not signify the absence of fractures underlying Lake Okeechobee. 

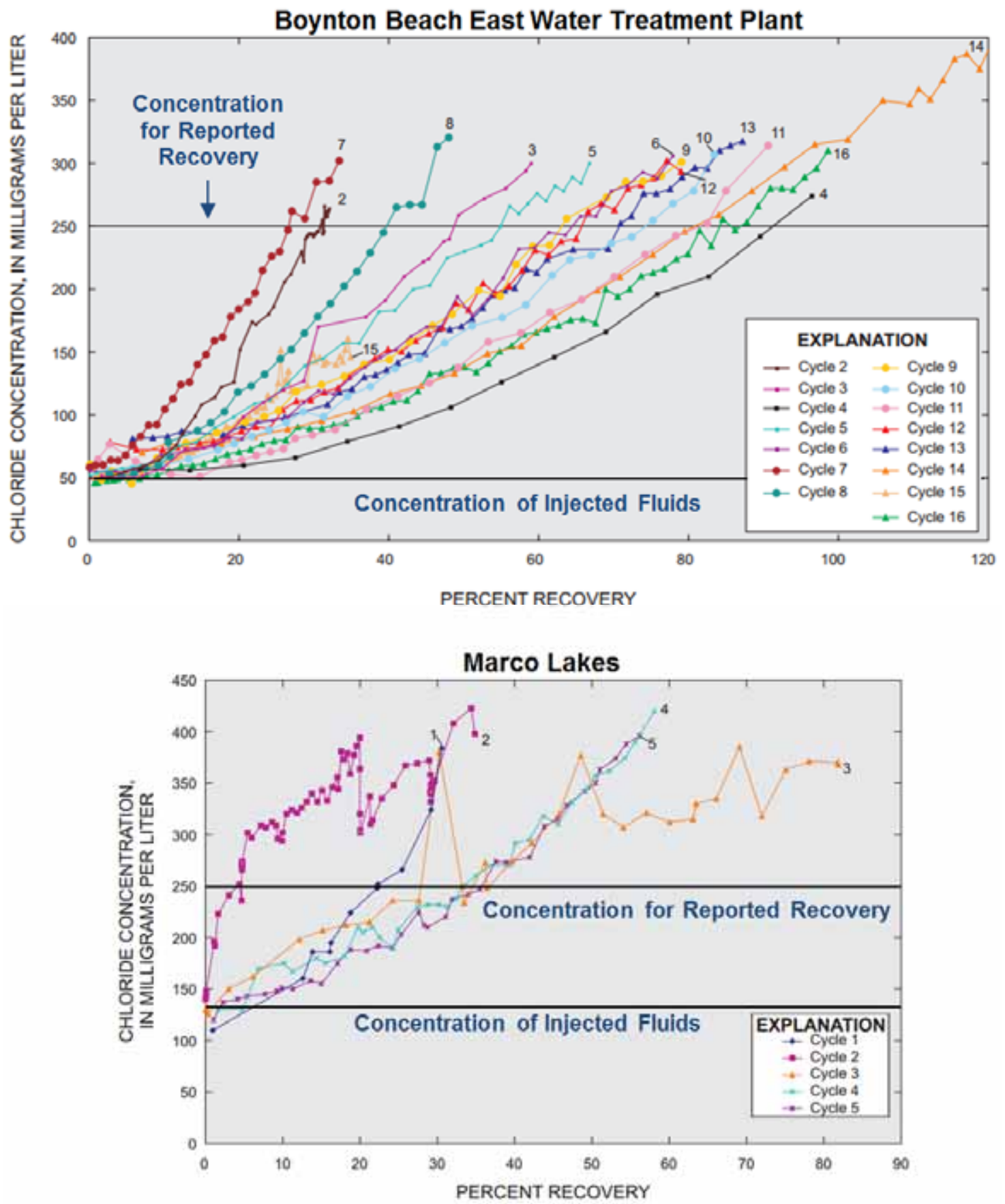

Figure 4. East coast (Boynton Beach East WTP) and west coast (Marco Lakes) examples of reported and actual "recovery" from ASR wells in the vicinity of the Greater Everglades Basin and associated counties, Florida (modified from Reese, 2002 by adding horizontal limits of concentration)

Only a few of the fractures that were identified in southwest Florida in the draft ACOE report (2004c) are similar in proximity and orientation to those mapped in that area by the Remote Sensing Section of FDOT (1973). One example is the most southern fracture oriented northwest to southeast along the coast of southwest Collier County (Figure 4). The length of that fracture, based on the draft ACOE report (2004c), extended only $38 \mathrm{~km}$ (23 $\mathrm{mi}$ ) and was confined to the southwest corner of Collier County, while the fracture mapped by FDOT in that vicinity extended for $133 \mathrm{~km}$ (82 mi), from the west coast to the east coast of Florida, across Collier, Monroe and Dade Counties (Figure 5). 


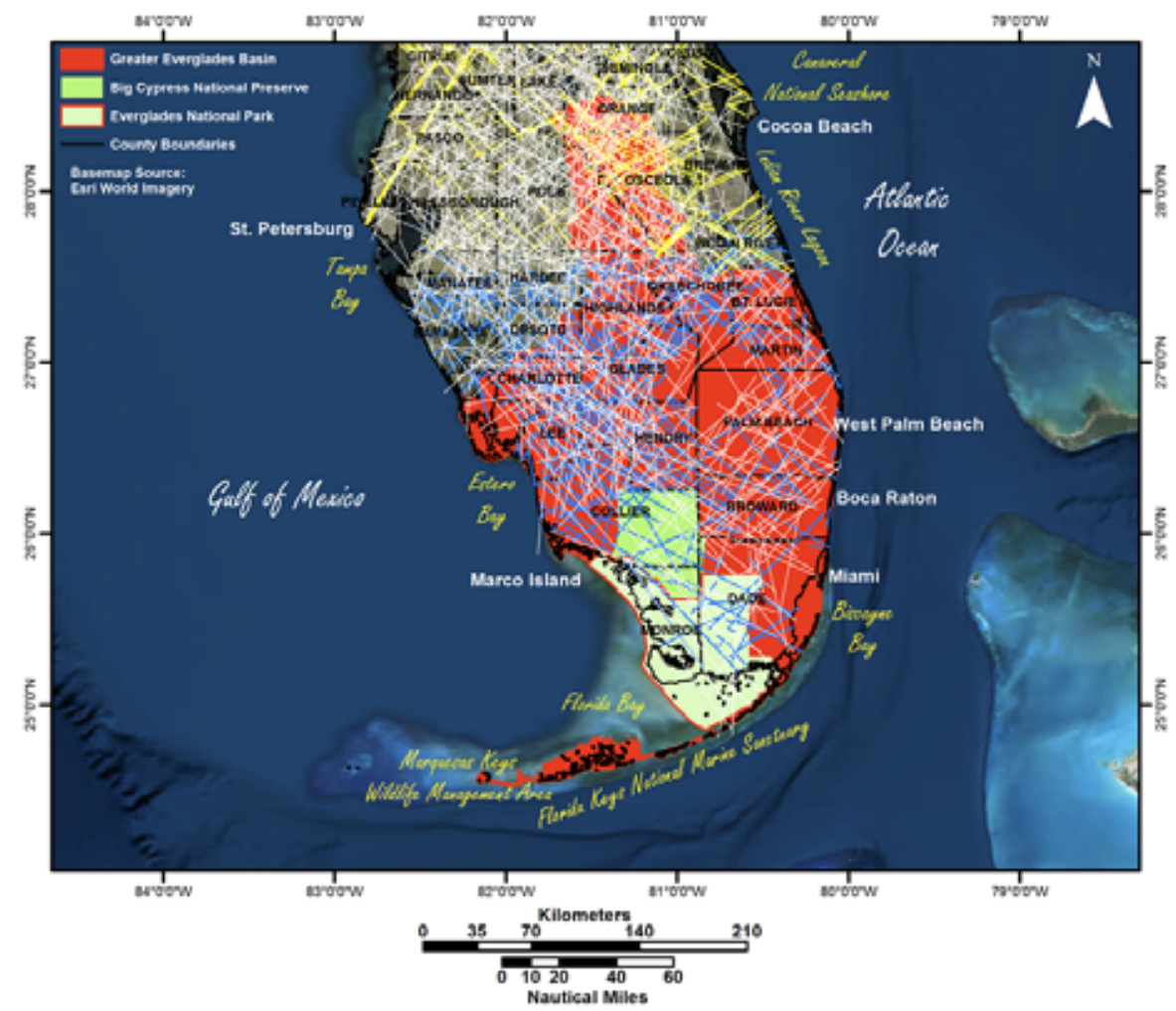

Figure 5. Locations of fractures mapped by Vernon (1951, diagonal yellow lines), FDOT (1973, diagonal white lines) and reported by ACOE (2004c, diagonal blue lines) in the vicinity of the Greater Everglades Basin and associated counties
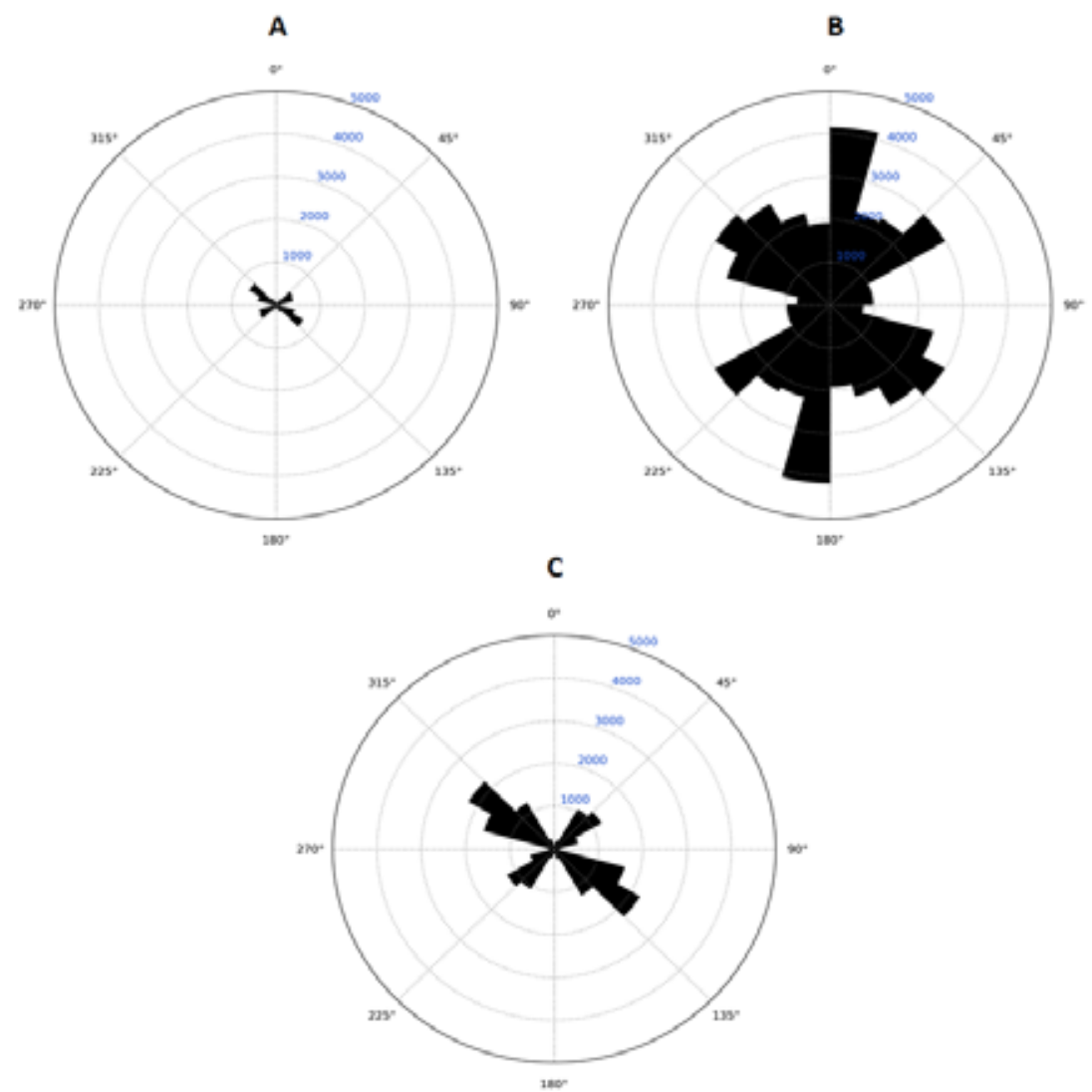

Figure 6. Length-weighted rose diagrams showing distribution density for fractures mapped in the Greater Everglades Basin by A. Vernon (1951); B. FDOT (1973); and C. ACOE (2004c) 


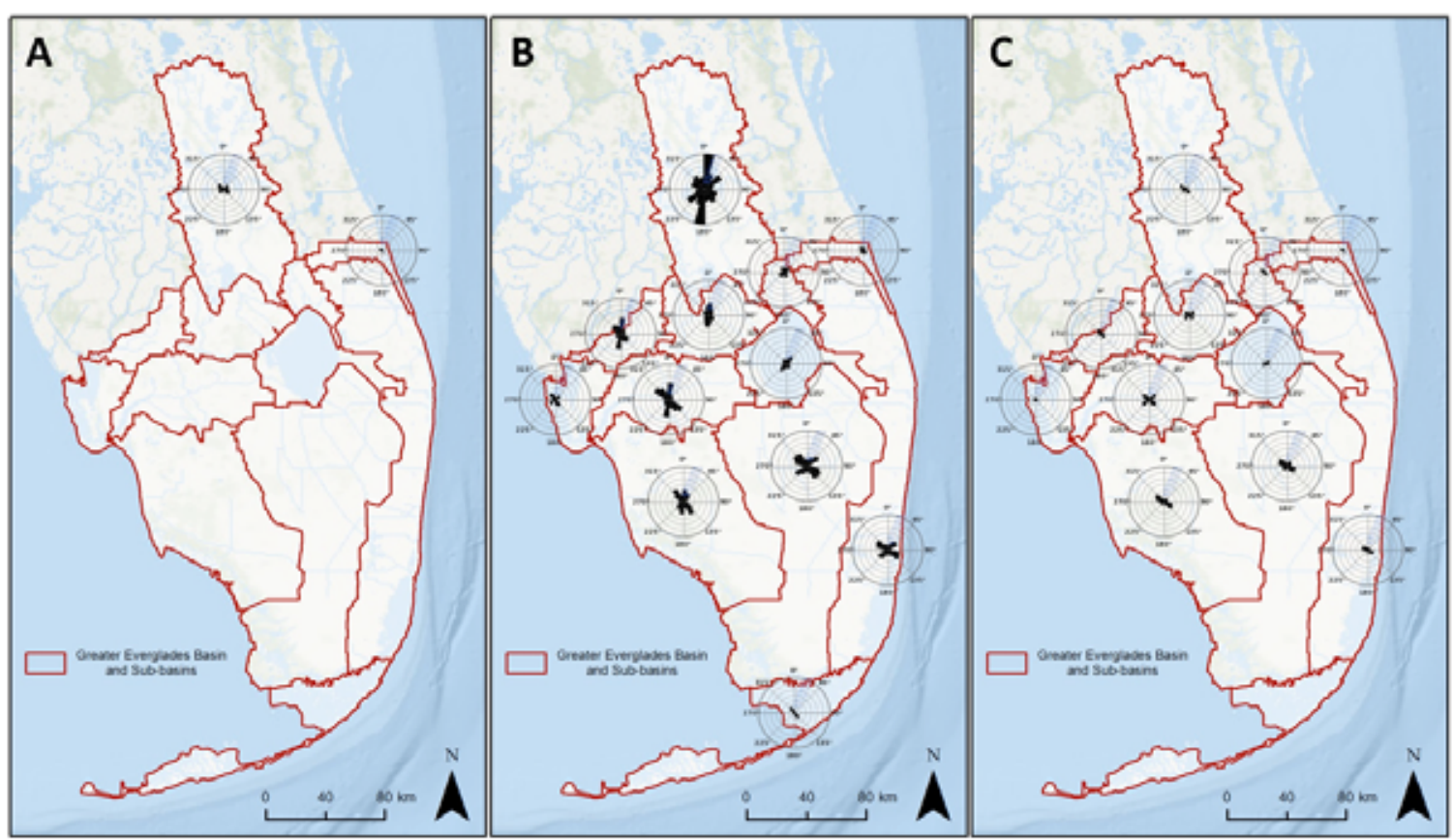

Figure 7. Length-weighted rose diagrams showing distribution density for fractures mapped in each sub-basin of the Greater Everglades Basin by A. Vernon (1951); B. FDOT (1973); and C. ACOE (2004c)

\subsection{Frequency and Lengths of Fractures in the Vicinity of the Greater Everglades Basin}

Table 4 summarizes the frequency of fractures, lengths of shortest and longest fractures and mean fracture lengths from ACOE (2004c), FDOT (1973) and Vernon (1951) fractures in counties included entirely or partially within the basin. Results provided in Table 4 also indicate which counties included in the basin were not considered by ACOE (2004c) and Vernon (1951). The greatest frequency of fractures mapped by Vernon (1951) occurred in Osceola County (59), followed in descending order by Orange (42), Polk (40), Lake (33), Okeechobee (8) and St. Lucie (4) Counties (Table 4). A triple-digit frequency of fractures mapped by FDOT (1973) occurred in Polk (142), Lake (121) and Osceola (106) Counties (Table 4). The remaining counties entirely or partially within the basin each had a double-digit frequency of fractures mapped by FDOT (1973) and the frequency in all of those counties was greater than the frequency of fractures mapped by Vernon (1951) in each of those counties. Each of the counties also included a double-digit frequency of fractures reported by ACOE (2004), except for Lake and Orange Counties, which were not included in that draft report by the ACOE (2004) and Osceola and Polk Counties. The greatest frequency of those fractures occurred in Highlands (79), Hendry (75), Glades (74) and Okeechobee (67) Counties. When all of the fractures in those three data sets are combined for each county, Polk County has the greatest frequency of fractures (185) and a total of 10 of the 18 counties have a triple-digit frequency of fractures, with the remaining counties having a double-digit frequency of fractures (Table 4).

The longest fracture mapped by Vernon (1951) was approximately $155 \mathrm{~km}(97 \mathrm{mi})$ in length and extended through Lake, Orange and Osceola Counties associated with the basin. The shortest fracture mapped by FDOT (1973) was approximately $5 \mathrm{~km}$ (3 mi), which was more than twice as long as the shortest fracture mapped by Vernon (1951) and more than 3.5 times as long as the shortest fracture mapped by ACOE (2004c). The longest fracture mapped by FDOT (1973) was approximately $400 \mathrm{~km}$ (249 mi) in length and extended through DeSoto, Lake, Orange, Osceola and Polk Counties. The longest fracture reported by ACOE (2004c) was approximately $291 \mathrm{~km}(180 \mathrm{mi})$ in length and extended through Collier, Dade, Glades, Henndry, Lee and Monroe, while other fractures reported by ACOE extended through Palm Beach and St. Lucie Counties. Mean fracture lengths for counties associated with the basin ranged from approximately 22-39 km (13-24 mi), 83-128 km (51-79 mi) and 11-55 km (6-34 mi) for Vernon (1951), FDOT (1973) and ACOE (2004c) fractures (Table 4). Figure 8 includes histograms of the lengths of fractures mapped from aerial photographs (Vernon, 1951) and satellite images (FDOT, 1973 and ACOE, 2004c) in each of the 18 counties entirely or partially within the Greater Everglades Basin. 
Table 4. Frequency of fractures, lengths of shortest and longest fractures and mean fracture lengths for ACOE (2004c), FDOT (1973) and Vernon (1951) in counties within the Greater Everglades Basin

\begin{tabular}{|c|c|c|c|c|c|c|c|c|c|c|}
\hline \multirow[b]{2}{*}{ County } & \multicolumn{3}{|c|}{ Total Fractures } & \multirow{2}{*}{$\begin{array}{c}\text { Total } \\
\text { Combined } \\
\text { Fractures }\end{array}$} & \multicolumn{3}{|c|}{ Shortest-Longest Fractures (km) } & \multicolumn{3}{|c|}{ Mean Fracture Length (km) } \\
\hline & Vernon & FDOT & $\triangle \mathrm{COE}$ & & Vernon & FDOT & ACOE & Vernon & FDOT & $\triangle \mathrm{COE}$ \\
\hline Bronward & - & 36 & 29 & 65 & - & $7.2-236.7$ & $1.6-101.1$ & - & 95.5 & 33.1 \\
\hline Charlottex & - & 45 & 47 & 92 & - & $20.8-4(0) .4$ & $23-1056$ & - & 127.6 & 259 \\
\hline Collier & - & 18 & 53 & 101 & - & $24.0-3130$ & $3.9-1 \div 9.3$ & - & 121.4 & 43.1 \\
\hline Dade & - & 38 & 32 & 30 & - & $21.6-31.30$ & $1.7-179.3$ & - & 980 & 326 \\
\hline DeSolo* & - & 16 & 51 & 100 & - & $21.8-1(x) .4$ & $2.2-1.18 .2$ & - & 1204 & 19.9 \\
\hline Cilades & - & 48 & 74 & 122 & - & $22.5-287.8$ & $1.3-148.2$ & - & 115.7 & 218 \\
\hline Hendry & - & \$1 & 75 & 136 & - & $26.4-287.8$ & $29-148.2$ & - & 116.1 & 29.5 \\
\hline IIiglulands* & - & 71 & 79 & 150 & - & $6.5-265.4$ & $1.7-148.2$ & - & 99.6 & 21.1 \\
\hline Lake* & 33 & 121 & - & 154 & $3.2-154.6$ & $4.7-4(x) .4$ & - & 35.3 & 83.1 & - \\
\hline Lee & - & 38 & 43 & 81 & - & $20.8-313.0$ & $2.5-105.6$ & - & 118.0 & 31.1 \\
\hline Matin & - & 22 & 26 & 48 & - & $31.6-225.0$ & $1.9-301.5$ & - & 910 & 11.2 \\
\hline Monirue & - & 21 & 11 & 35 & - & $18.0-3130$ & $4.1-179.3$ & - & 111.0 & 49.7 \\
\hline (ckeechobee & 8 & 50 & $6 ?$ & 125 & $12.1-47.1$ & $20.3-2250$ & $18-1109$ & 29.8 & 102.2 & 16.4 \\
\hline irange* & 12 & 96 & - & 138 & $6.3-151.6$ & $11.3-1(x) A$ & - & 39.1 & 93.2 & - \\
\hline ()sceola & 59 & 106 & 4 & 169 & $2.6-1.54 .6$ & $130-4(0) .4$ & $21.8-75.4$ & 35.6 & 101.2 & 49.1 \\
\hline P'alrn Béacl1* & - & 43 & 35 & 78 & - & 39.3 - 235.0 & $28-78.5$ & - & 91.1 & 23.1 \\
\hline Polk-* & 40 & 142 & 3 & 185 & $2.2-77.6$ & $6.5-400.4$ & $11.5-1109$ & 22.4 & 94.7 & 54.7 \\
\hline \multirow[t]{2}{*}{ St Lucic } & 4 & 26 & 25 & 55 & $26-57.4$ & $31.6-214.3$ & $3.6-51.5$ & 37.5 & 99.7 & 13.2 \\
\hline & & & & & $2.2-154.6$ & $4.7-4(x) .4$ & 13.3015 & & & \\
\hline
\end{tabular}

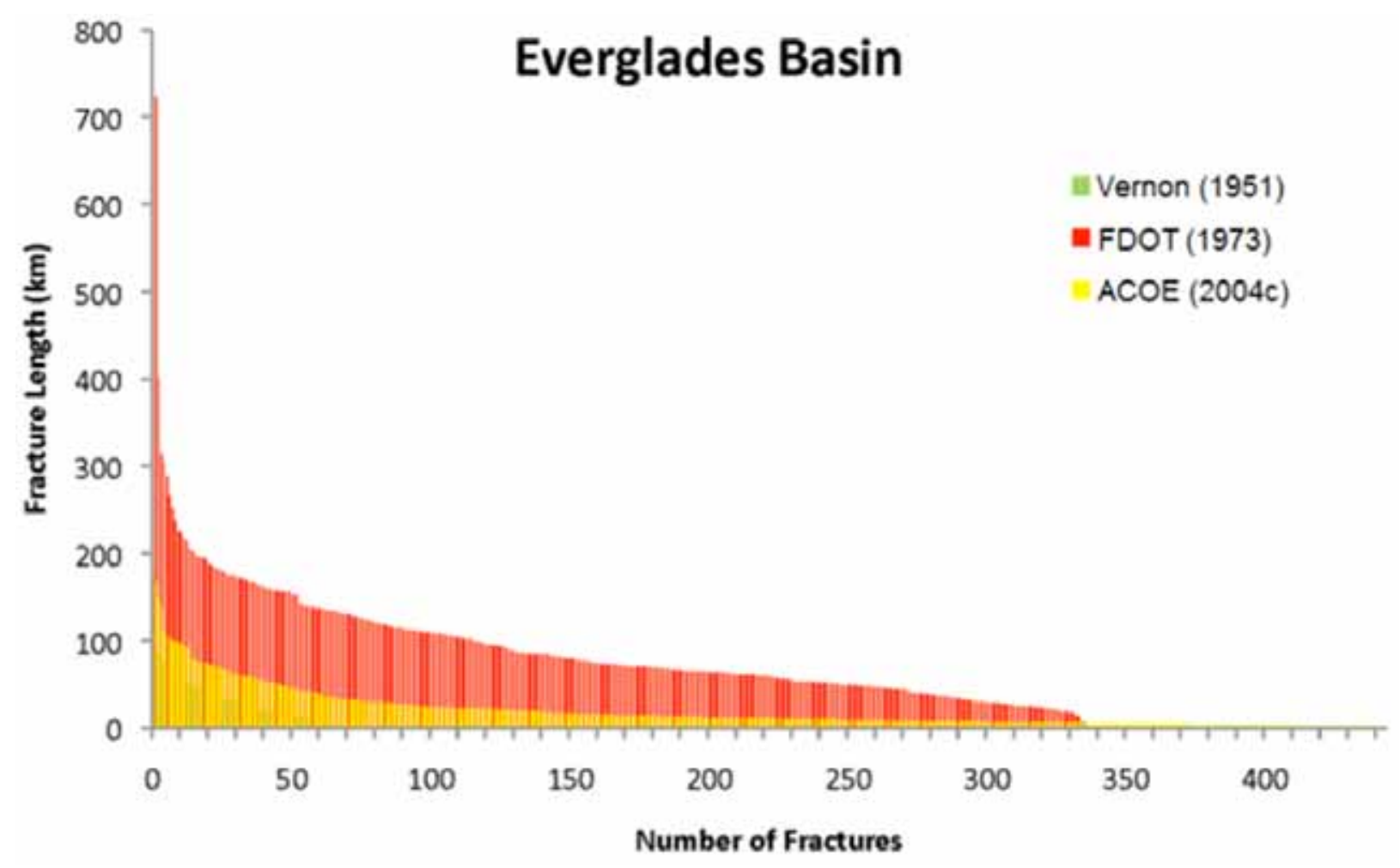

A 


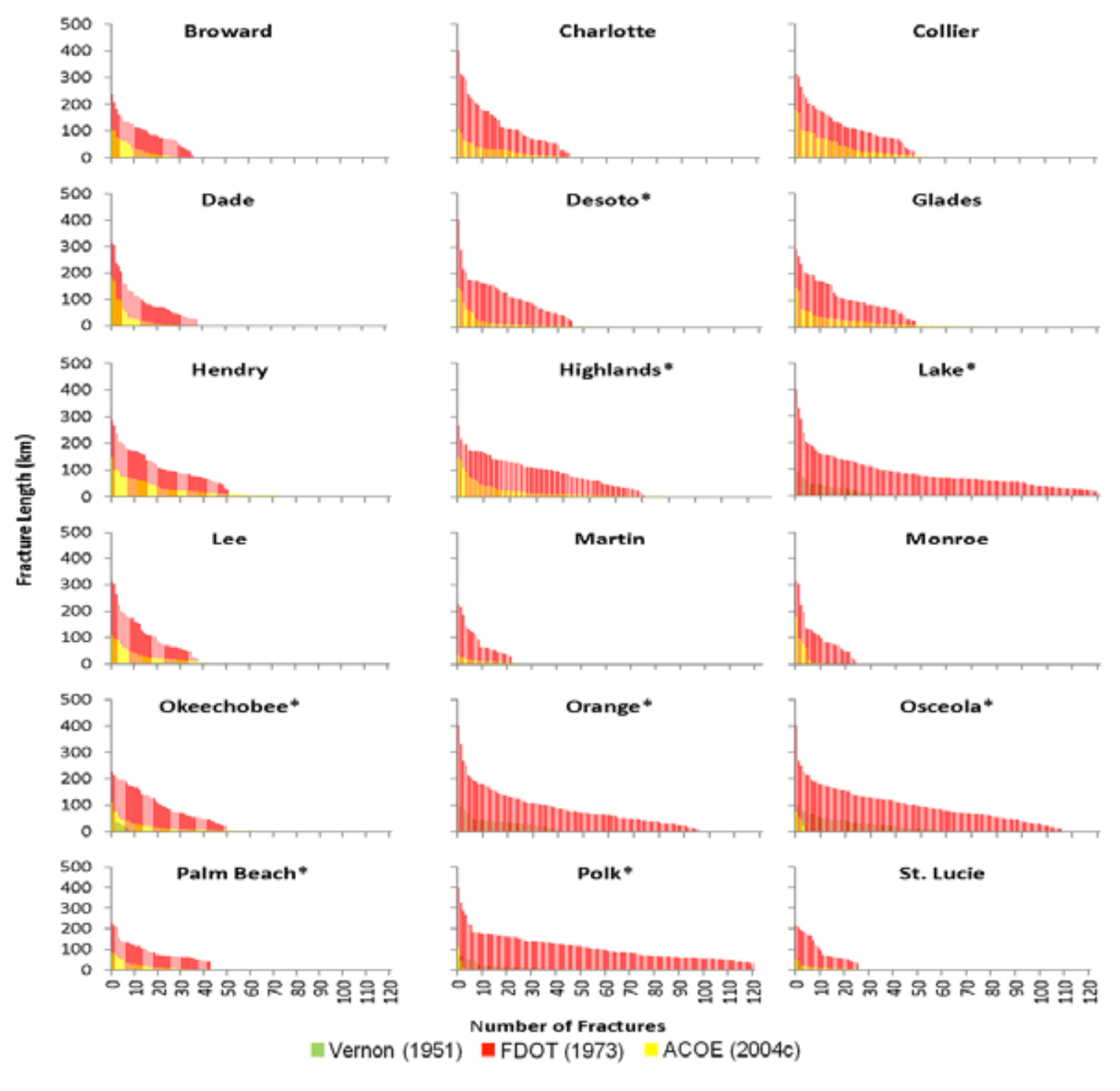

Figure 8. Length of fractures mapped from ACOE (2004c), FDOT (1973) and Vernon (1951) in: A. the entire Greater Everglades Basin and B. each individual county located entirely or partially $\left({ }^{*}\right)$ within the Greater Everglades Basin

Figure 8A shows that the longest and most numerous fractures in the basin (approximately 350 fractures) are from the FDOT (1973) data set, with the longest fractures exceeding $700 \mathrm{~km}$. The fractures mapped by Vernon (1951) represented the shortest and least numerous in the basin (approximately 60 fractures), because Vernon's study area primarily was north of the basin. The longest fracture mapped by Vernon (1951) in the basin was approximately $100 \mathrm{~km}$ (Figure 8A). Portions of fractures from the Vernon (1951) study only occur in the following six of counties in the basin: Lake, Okeechobee, Orange, Osceola, Polk and St. Lucie. Therefore, none of the remaining county histograms shown in the Figure 8B include any fractures from the Vernon (1951) study. Additionally, Lake and Orange Counties included no fractures from the ACOE (2004c) data set. Therefore, the county histograms shown in the Figure $8 \mathrm{~B}$ for those two counties do not include any fractures from the ACOE (2004c) data set. Figure 8B also illustrates which counties have the greatest number of fractures (primarily from the FDOT (1973) data set), with approximately 120 fractures occurring in Lake and Polk Counties, where phosphate mining was initiated decades ago. The longest fractures associated with the 18 counties of the basin were $40 \mathrm{~km}$ and occurred in Charlotte, DeSoto, Lake, Orange, Osceola and Polk Counties. Collier, Dade, Glades, Hendry, Lee and Monroe Counties included fractures approximately $300 \mathrm{~km}$ long. The longest fractures associated with the remaining two counties, Palm Beach and St. Lucie, were approximately $200 \mathrm{~km}$ long (Figure 8B). 
4.4 Locations and Frequency of ASR Wells, Other Injection and Withdrawal Wells, Modern Sinkholes, Fractures and Fracture Intersections

Table 5 summarizes the frequency of ASR wells, other injection and withdrawal wells, modern sinkholes and fracture intersections for ACOE (2004c), FDOT (1973) and Vernon (1951) fractures in counties associated with the basin. In descending order, Lee (23), DeSoto (22), Collier (21), Orange (10) and Palm Beach (9) Counties have the greatest numbers of the 110 permitted ASR wells of the counties analyzed in our study. The FDEP has permitted 11,561 injection wells associated with the basin (e.g., primarily for injection of sewage effluent and industrial contaminants). The greatest numbers of injection wells, in descending order, are in Dade $(8,181)$, Monroe (1,026), Broward (737), Collier (436), Polk (347), Orange (278), Palm Beach (221), Lee (135) and Charlotte (105) Counties. A total of 117,098 withdrawal wells has been permitted by the SFWMD, SWFWMD and SJRWMD in counties associated with the basin. The greatest numbers of these withdrawal wells are in Palm Beach $(21,149)$ and Lee $(14,593)$ Counties. All of the remaining counties have thousands of withdrawal wells except for Monroe County, where only limited areas of non-saline ground water occur. The greatest frequency of the modern sinkholes reported in counties associated with the basin occurs in Polk (225), Orange (191) and Lake (100) Counties, in descending order. Those same counties, in addition to Osceola County $(1,421)$ have the greatest frequency of fracture intersections $(1,578,1,027$ and 1,058, respectively) of the 10,638 fracture intersections in counties associated with the basin. Figure 9 illustrates the proximity of fractures to permitted ASR wells in the vicinity of the basin and associated counties (Figure 9A), in the southern extent of the basin (Figure 9B) and in the northern extent of the basin and associated counties (Figure 9C) in the three data sets evaluated in our study (ACOE, 2004c; FDOT, 1973; Vernon, 1951). The proximity of fractures to permitted ASR wells, other Class V injection wells, Class I injection wells and modern sinkholes in the three data sets evaluated in our study is illustrated in Figure 10A. Figure 10B depicts the proximity of fractures in the three data sets evaluated in our study to permitted ASR wells, other withdrawal wells (permitted by the SFWMD, SWFWMD and SJRWMD) and modern sinkholes.

Table 5. Frequency of ASR wells, other injection and withdrawal wells, modern sinkholes and fracture intersections for ACOE (2004c), FDOT (1973) and Vernon (1951) fractures in counties associated with the Greater Everglades Basin.

\begin{tabular}{cccccc}
\hline County & $\begin{array}{c}\text { ASR } \\
\text { Wells }\end{array}$ & $\begin{array}{c}\text { Injection } \\
\text { Wells }\end{array}$ & $\begin{array}{c}\text { Withdrawal } \\
\text { Wells }\end{array}$ & $\begin{array}{c}\text { Modern } \\
\text { Sinkholes }\end{array}$ & $\begin{array}{c}\text { Fracture } \\
\text { Intersections }\end{array}$ \\
\hline Broward & 4 & 737 & 1,2464 & 3 & 225 \\
Charlotte* & 5 & 105 & 1,692 & 0 & 531 \\
Collier & 21 & 436 & 9,910 & 2 & 537 \\
Dade & 7 & 8,181 & 1,3572 & 1 & 234 \\
DeSoto* & 22 & 25 & 2,270 & 0 & 471 \\
Glades & 1 & 2 & 1,150 & 0 & 610 \\
Hendry & 1 & 6 & 4,946 & 1 & 770 \\
Highlands* & 1 & 2 & 4,737 & 9 & 723 \\
Lake* & 0 & 12 & 1,697 & 100 & 1,058 \\
Lee & 23 & 135 & 14,593 & 2 & 354 \\
Martin & 1 & 19 & 5,167 & 0 & 80 \\
Monroe & 1 & 1,026 & 45 & 1 & 51 \\
Okeechobee* & 2 & 8 & 2,322 & 0 & 526 \\
Orange* & 10 & 278 & 2,702 & 191 & 1,027 \\
Osceola* & 0 & 2 & 2,394 & 6 & 1,421 \\
Palm Beach* & 9 & 221 & 21,149 & 2 & $3(\mathbf{x})$ \\
Polk* & 1 & 347 & 8,321 & 225 & 1,578 \\
St. Lucie & 1 & 19 & 7,667 & 0 & 142 \\
\hline Totals & $\mathbf{1 1 0}$ & $\mathbf{1 1 , 5 6 1}$ & $\mathbf{1 1 7 , 0 9 8}$ & $\mathbf{5 4 3}$ & $\mathbf{1 0 , 6 3 8}$ \\
\hline
\end{tabular}

* counties partially included within the Greater Everglades Basin 


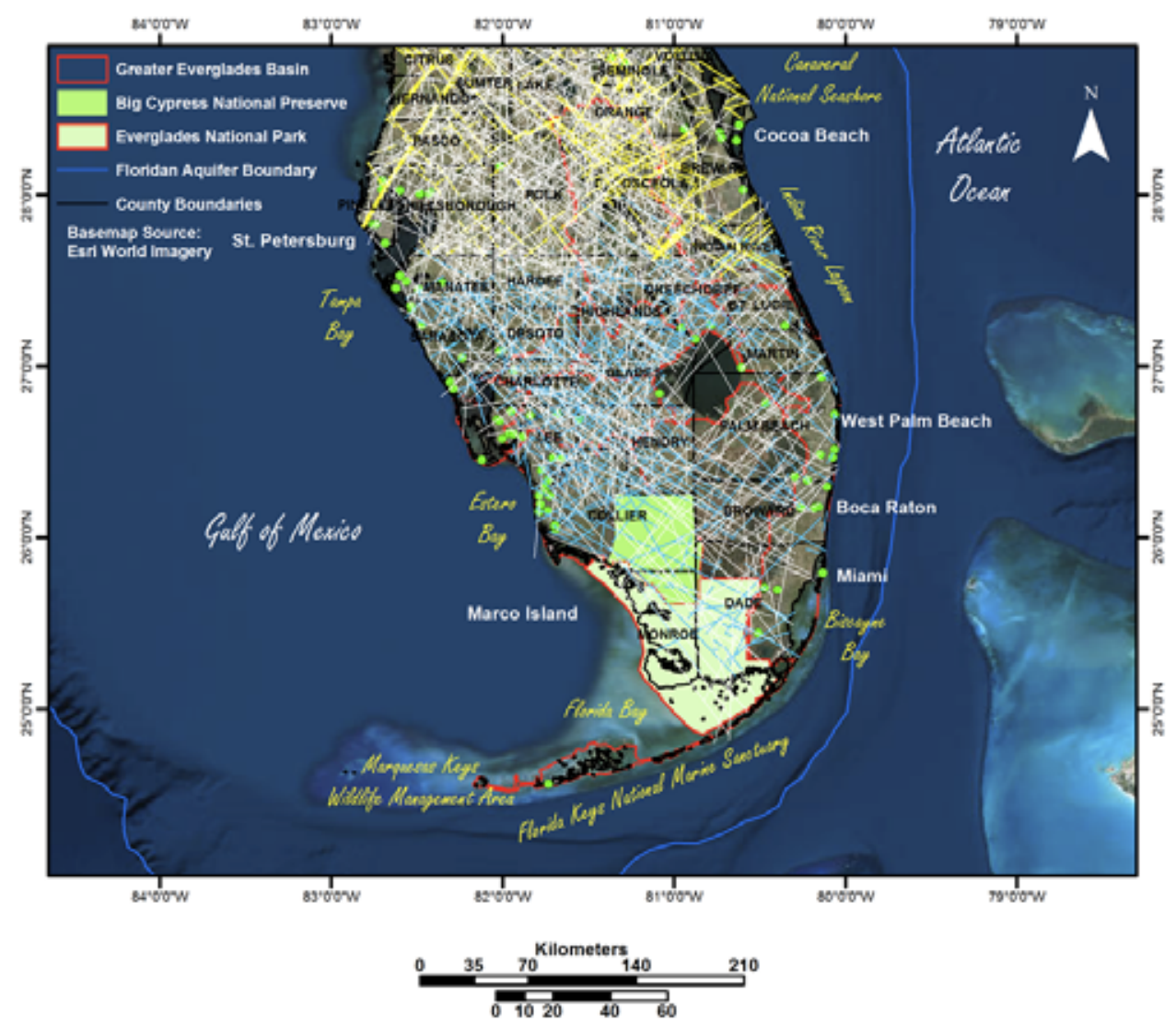

A

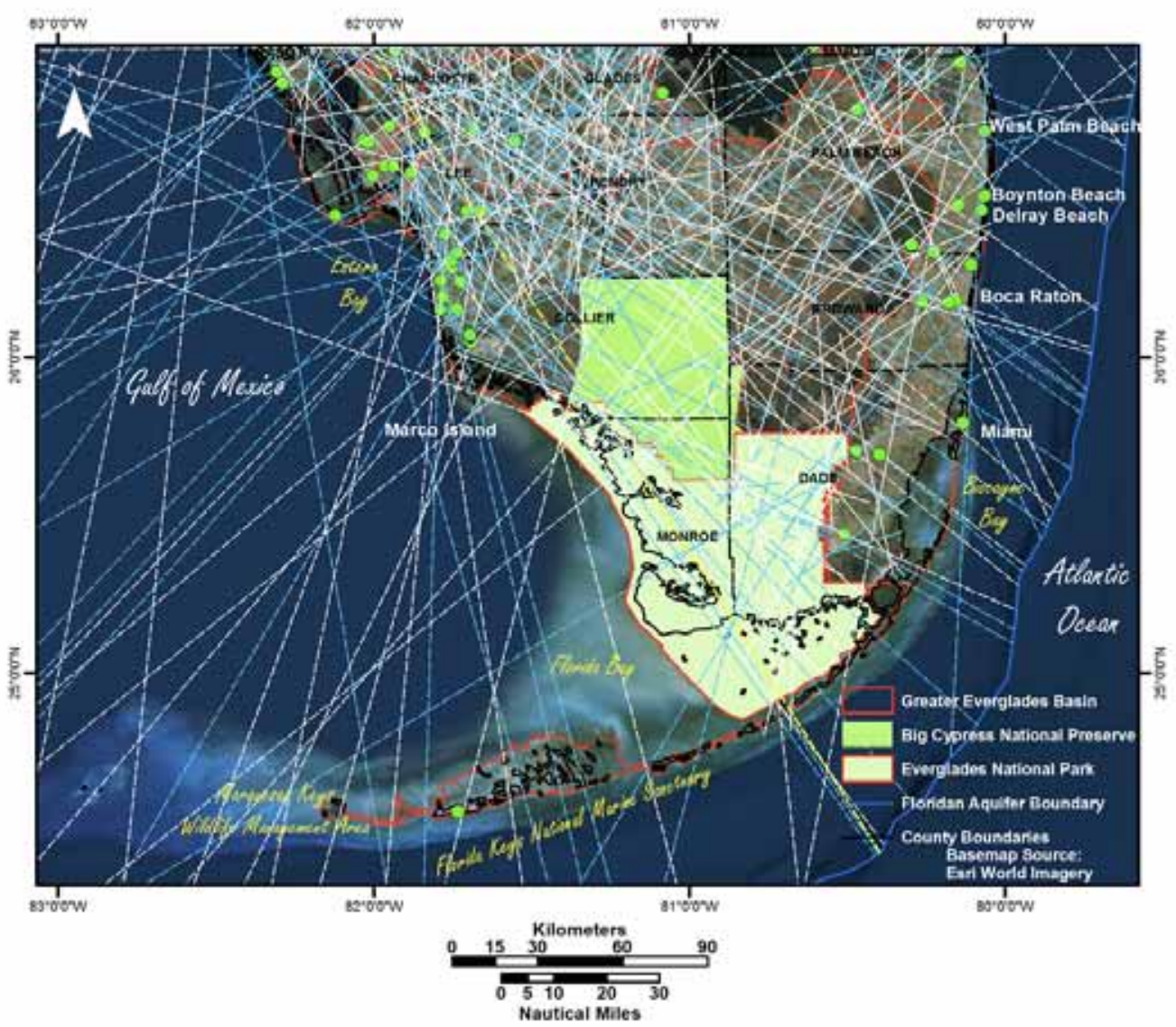




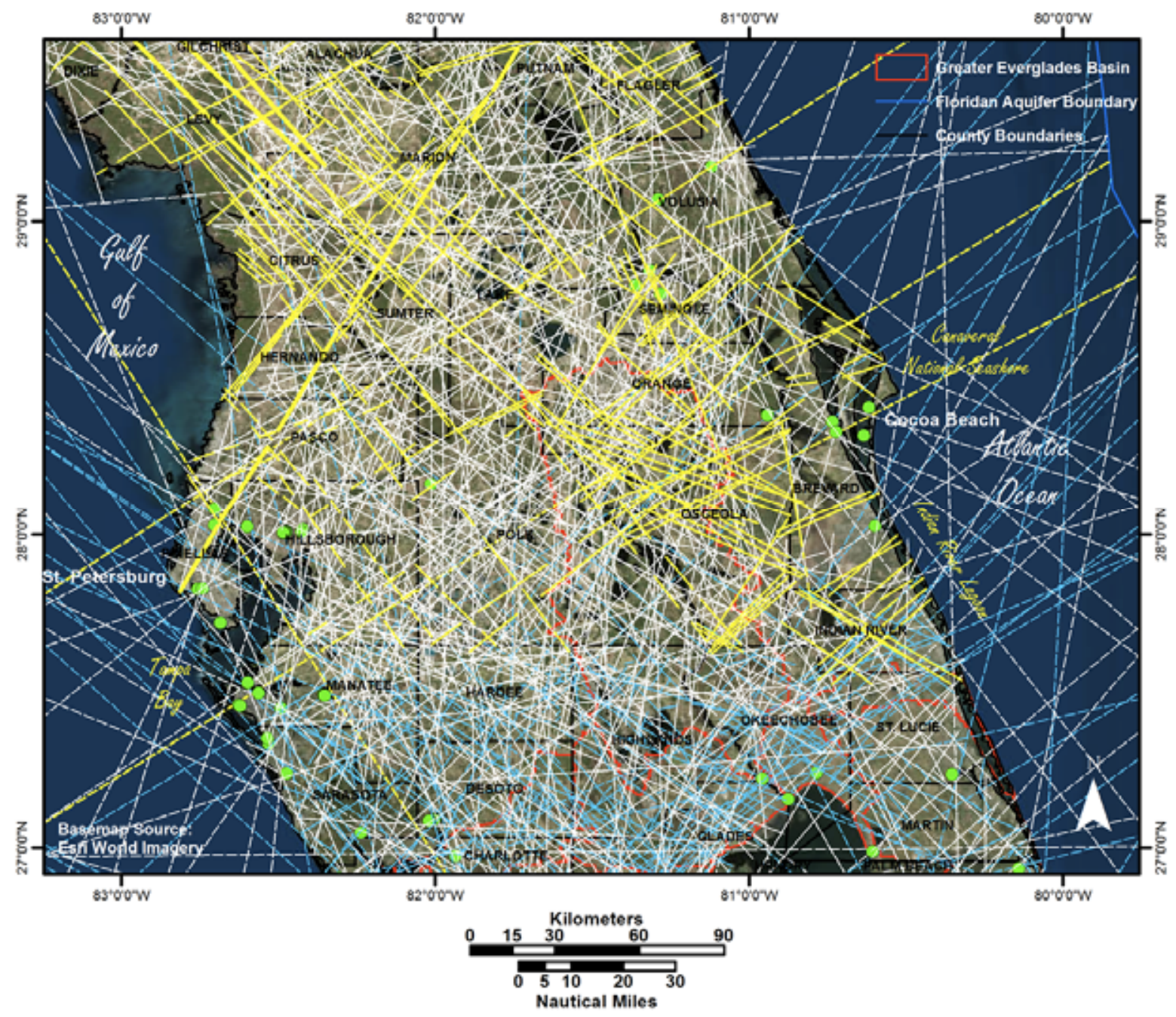

C

Figure 9. Proximity of permitted ASR wells (green circles) to fractures reported by ACOE (2004c, solid diagonal blue lines), and mapped by FDOT (1973, solid diagonal white lines) and Vernon (1951, solid diagonal yellow lines) and extensions of those fractures in proximity to ASR wells (dashed diagonal lines): A. in the vicinity of the Greater Everglades Basin and associated counties; B. in the southern extent of the Greater Everglades Basin; and C. in the northern extent of the Greater Everglades Basin and associated counties

Figure 9 includes the approximate submarine boundary of the Florida aquifer system, also known as the continental shelf, where the extension of some of the fractures mapped on the Florida peninsular have been documented. Fractures associated with existing ASR wells have been extended to that submarine boundary in the Atlantic Ocean and Gulf of Mexico in Figure 9B and 9C as dashed lines, with the same colors used for the three fracture data sets on the peninsular. These dashed lines illustrate the potential pathways for the preferential flow of fluids injected into ASR wells and the discharge of those fluids into near-shore coastal waters. These same fractures also could result in the preferential flow of saline water to inland portions of the aquifer system during withdrawals from those ASR wells. This study was not designed to anaylize the similarity in positions of fractures in the three data sets, but fractures from individual data sets did not appear to coincide with fractures from other data sets. 


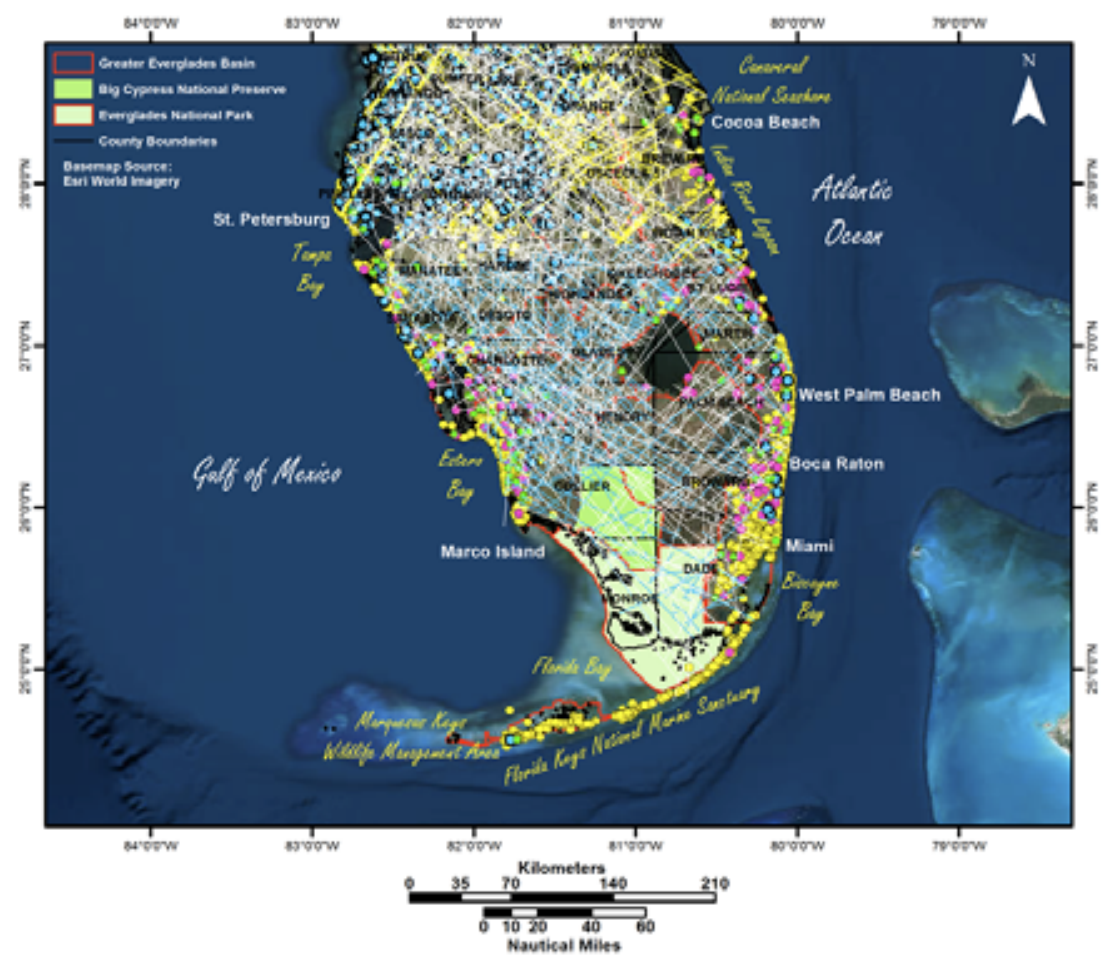

A

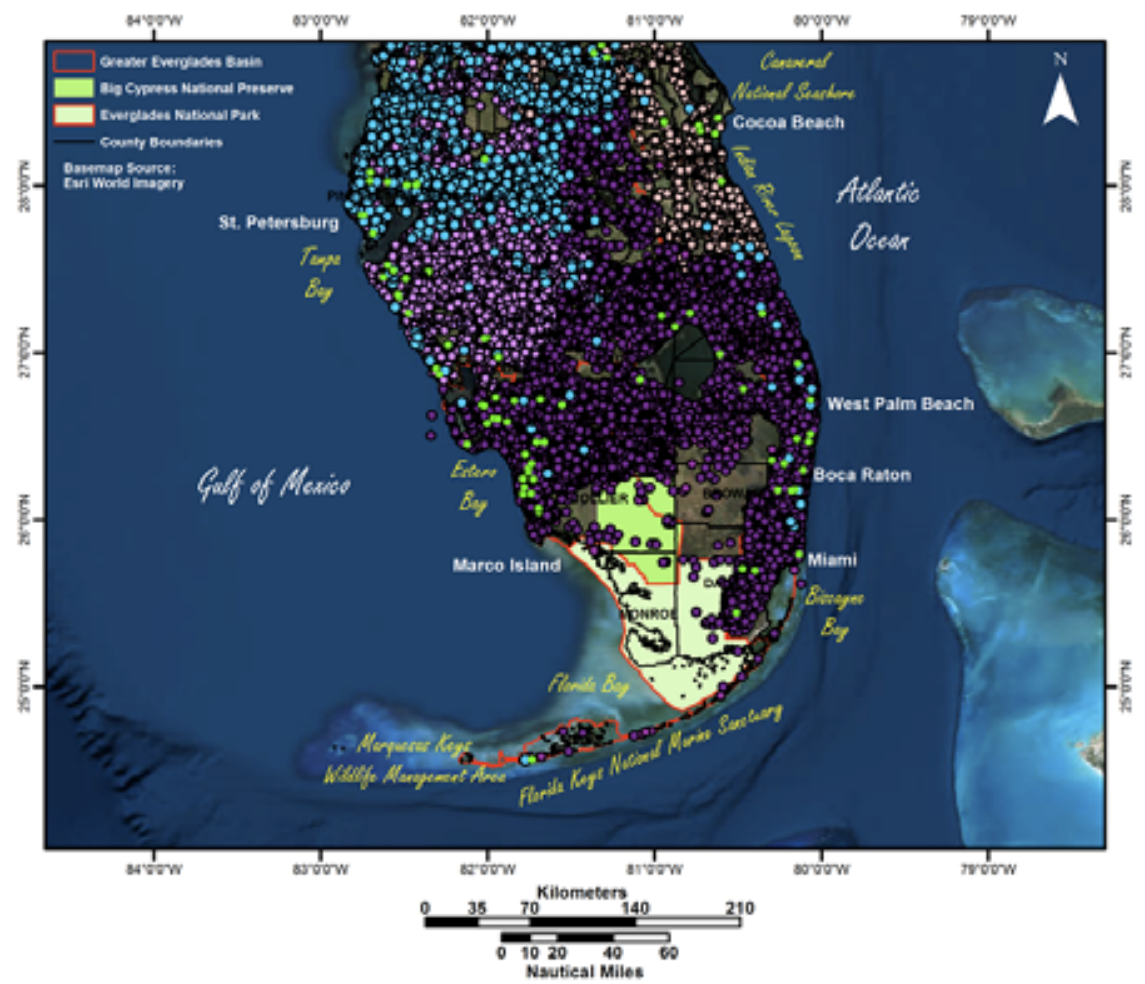

B

Figure 10. Proximity of fractures reported by ACOE (2004c) and mapped by FDOT (1973) and Vernon (1951), as described in Figure 9, in the vicinity of the Greater Everglades Basin and associated counties to: A. permitted ASR wells (green circles), other Class V injection wells (pink circles), Class I injection wells (yellow circles) and modern sinkholes (blue circles) and B. permitted ASR wells, other withdrawal wells permitted by SFWMD (purple circles), SWFWMD (lavender circles) and SJRWMD (pale pink circles) and modern sinkholes (blue circles) 
Figure 9A-D are histograms of the proximity of ASR wells, other injection wells, other withdrawal wells and sinkholes in the basin, respectively, to fractures in each of the three data sets and to all fractures combined. Approximately 50 ASR wells are located within $0.25 \mathrm{~km}$ of a fracture and the majority of the ASR wells are located within $2 \mathrm{~km}$ of a fracture from these three data sets (Figure 11A). A similar pattern occurs for the proximity of other aquifer-injection wells to fractures, with approximately 900 injection wells located within $0.25 \mathrm{~km}$ of a fracture from these three data sets (Figure 11B). More than 35,000 of other withdrawal wells are located within $0.25 \mathrm{~km}$ of a fracture from these three data sets (Figure 11C). Approximately 400 sinkholes are located within $0.25 \mathrm{~km}$ of a fracture from these three data sets (Figure 11D).

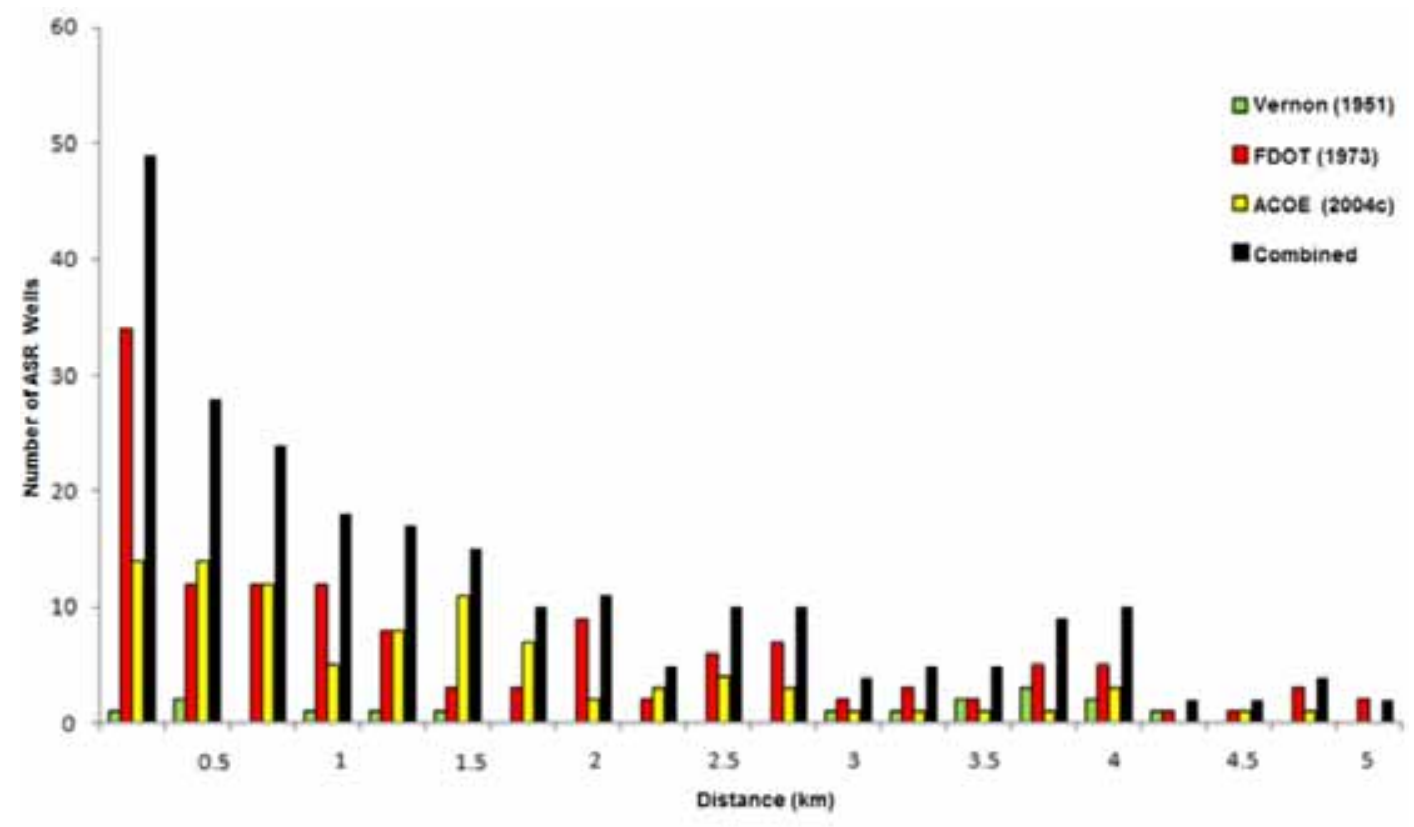

A

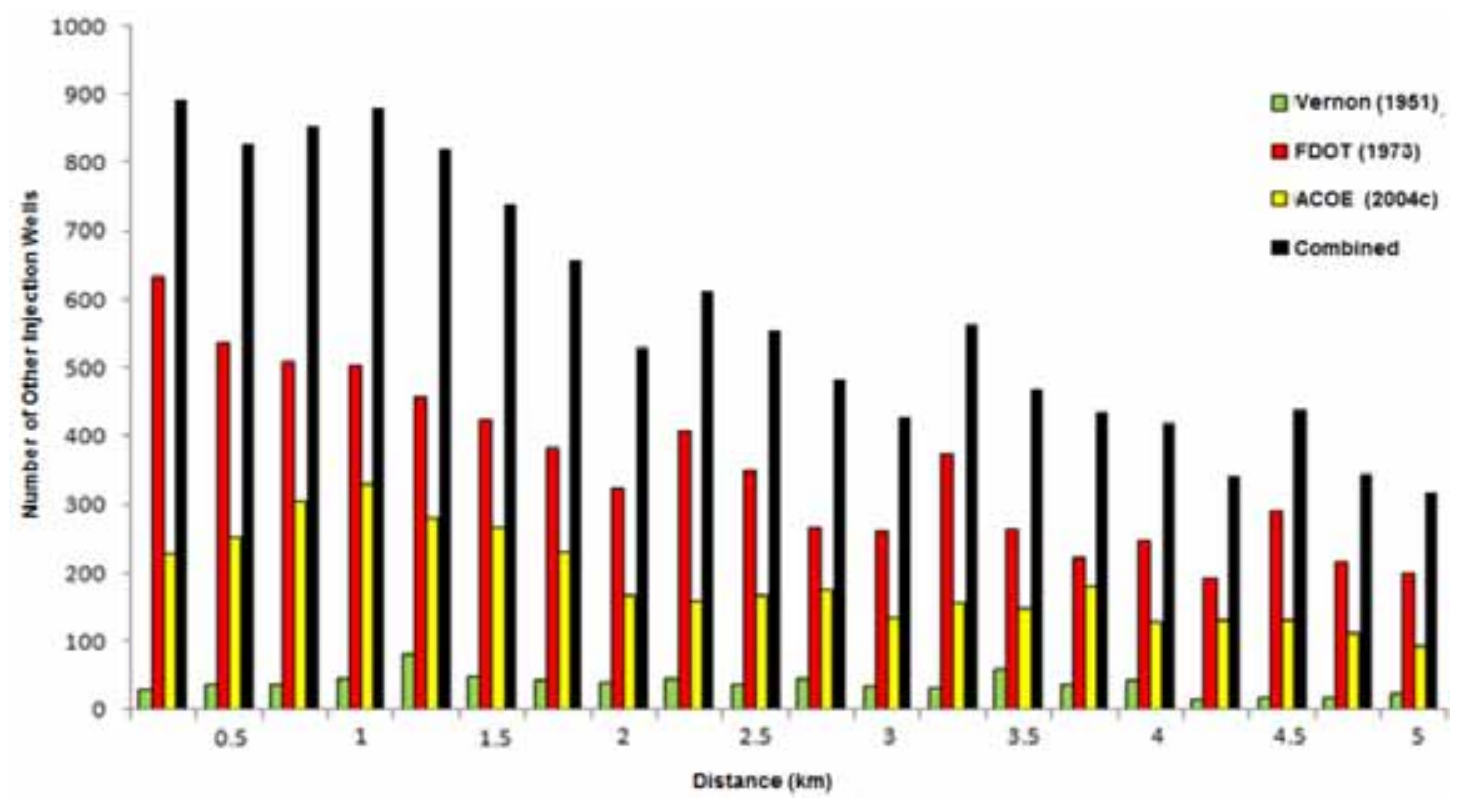

B 


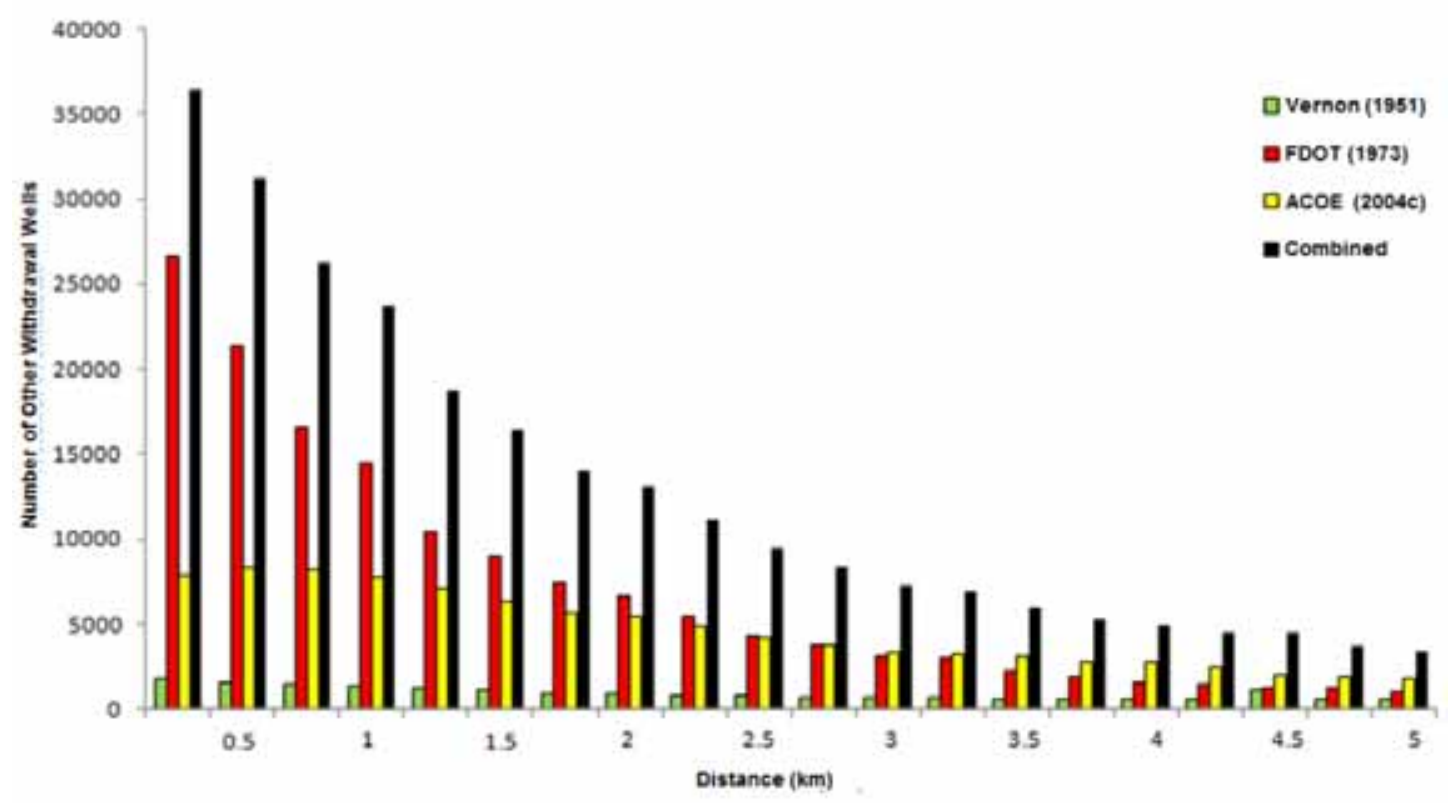

C

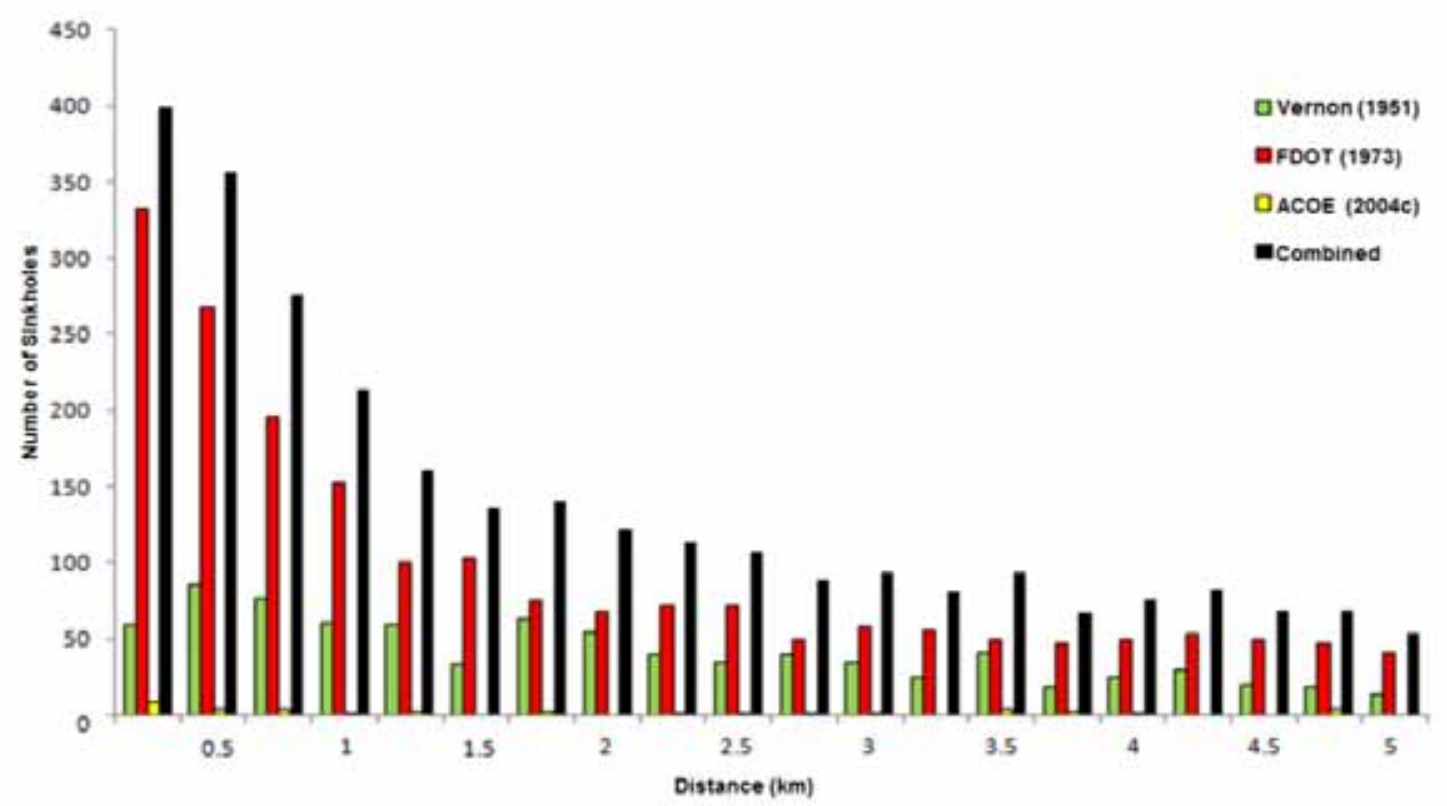

D

Figure 11. Distances from fractures reported by ACOE (2004c) and mapped by FDOT (1973) and Vernon (1951) in the Greater Everglades Basin for: A. ASR wells; B. Other injection wells; C. Other withdrawal wells; and

D. Sinkholes

\section{Discussion}

\subsection{Reported vs. Actual "Recovery" from ASR Wells}

Chloride is a component of the water in the aquifer zone where the ASR fluids are injected and is used to determine if water is brackish, saline or hypersaline. Therefore, chloride concentrations provide a readily available means of determining whether the nonsaline ASR fluids that are injected into an aquifer zone remain in an intact "bubble," as claimed in unpublished and published documents by agencies (e.g., Reese, 2002; 2004; Reese \& Alvarez-Zarikian, 2007) and other proponents of ASR (e.g., Brown, 2005; and the powerpoint presentation by R. David G. Pyne, ASR Systems LLC at the American GroundWater Trust IV convention in Tampa, Florida, April 15-16, 2004), or whether the injected fluids co-mingle with and/or displace the aquifer water. In cycle tests where the chloride concentrations were not recorded, actual "recovery" cannot be determined. For example, in the cycle tests where CH2M Hill did not provide the chloride concentration of the 
canal water that was injected during the ASR cycle test, the actual "recovery" of the cycle test that CH2M Hill conducted could not be determined. That type of omission in the available ASR data reflects the lack of basic scientific constraints at both the regulatory level and consultant/private industry level regarding ASR.

For the purposes of the USGS review, "recovery" was considered to be complete at a predetermined chloride level, regardless of the chloride concentration of the injected fluids (Reese, 2002, Table 5). The 250-mg/L chloride level selected by USGS to determine the reported "recovery" from tested ASR wells is related to the potable water standards for chloride levels under the SDWA, which is set at the designated level that water is considered too saline too drink.

In reality, the groundwater withdrawals during the part of the cycles representing the "recovery" period characteristically continued until the chloride concentration of the "recovered" water was more than twice the chloride concentration of the injected fluids. In numerous cases, the chloride concentration of the "recovery" water exceeded even the 250-mg/L chloride concentration that was supposed to signal the conclusion of the cycle test. For example, the chloride concentration of the "recovery" water was approximately 386 times greater than the chloride concentration of the injected water for the first cycle test of the ASR well conducted by CH2M Hill in Marathon (Florida Keys, Monroe County, see Table 5 from Reese, 2002).

The strikingly lower actual "recovery" values compared to reported "recovery" values in Table 3 are important in illustrating that none of those ASR cycles represent significant "recovery" of injected fluids. At best, ASR injections result in either rapid co-mingling of injected fluids with ground water or displacement of water and other fluids in the aquifer system (including the surficial aquifer) or both. That co-mingling was being referenced in the Florida Keys as "blended" water, in response to an increasingly educated public's concerns. In reality, the available data provide no evidence that any of the water injected into the ASR wells is capable of being recovered, particularly considering that ground water is not static, but flows. In fact, chloride contamination of the Floridan aquifer system has occurred via preferential flow through faults (Maslia \& Prowell, 1990). That provides additional support for the conclusion that there is no scientific basis for the determination of the reported "recovery" data and the actual "recovery" data only indicate the percentage of "recovery" based on the reported chloride content of the water that was injected and withdrawn. Despite the limitations of the data, the results are sufficient to confirm that widely held claims of ASR's success in southern Florida are not valid and that significant environmental harm should be expected from those injections and withdrawals.

\subsection{Disposal vs. "Storage"}

Common definitions of "recovery" include, "[T] get back:regain.” “[A]n act, instance, process, or period of recovering.” "[A] return to a normal condition.” (Soukhanov \& Ellis, 1984). It is difficult to justify use of the term "recovery" for ASR in southern Florida, based on the ranges of actual "recovery" provided in Table 3. The results taken from the data summarized by USGS more accurately constitute disposal rather than "recovery" and refute the theory accepted by funding and permitting agencies that injected fluids are retained as an intact "bubble" in the aquifer.

Actual "recovery" was not calculated for cycle test \#1 at the Springtree Water Treatment Plant in Broward County because the chloride concentration of the "recovered" fluids was lower than the chloride level of the injected fluids after a "storage" period of 0 days (i.e., withdrawals initiated immediately after the injections). The most plausible explanation is that the withdrawals during the "recovery" period resulted in induced "recharge," pulling nonsaline (lower chloride) water downward from the surficial aquifer. The induced "recharge" from the overylying surficial aquifer could have come from stormwater ponds, ditches, canals or other channelized or excavated areas that previously were natural freshwater wetlands and streams, such as those commonly associated with fractures. The Springtree ASR site is surrounded by those types of lower chloride surficial aquifer sources and the Everglades Wildlife Management Area is located to the west of the Springtree ASR well site, all of which are subject to induced "recharge" and preferential flow (e.g., fracture flow) in response to withdrawals from ASR wells. Subsequent cycles at that same facility yielded only 8.5\%, 10.1\%, $10.1 \%$ and $7.3 \%$ actual "recovery." Agency staff has attributed reduced "recovery" of subsequent cycle tests to clogging or plugging of the well with fine particles, thus reducing the volume of ground water that can be pulled from the aquifer (e.g., Thomas Scott, DEP, pers. comm., 9/26/00).

The available evidence, including comparisons of chloride concentrations for injected and "recovered" water, confirm that ASR has not fulfilled proponents' claims that ASR is a means of "storing" or "recovering" water injected into the aquifer, a "new water supply" and groundwater "recharge" alternative (Pyne, 1988), or a potential solution to the eutrophication of Lake Okeechobee and the Everglades, as proposed by Garcia-Bengochea and Muniz (1988). Despite the inadequacies of the Reese (2002) report and all subsequent 
reports that relied on the data and approaches described in that report, that inventory and review did provide valuable information about the alleged "performance," or more accurately, the lack of performance of ASR in southern Florida. Those results suggest that there is no apparent evidence that the results or "performance" of ASR were dependent on geographic area, ambient chloride concentration of the aquifer zone receiving the injections, chloride concentration of the injected fluids, injection volume, withdrawal volume, or possibly even the firm(s) responsible for construction/operation of the facilities. Regardless of the varying circumstances under which the more than 80 cycle tests occurred at the locations throughout southern Florida, none of the results could be considered as "storage" or "recovery" under the common definitions of those terms. The results more clearly fit the definition of underground disposal. Consequently, ASR wells simply function as additional "disposal" and water supply wells, without providing any additional aquifer capacity to support those groundwater withdrawals.

\subsection{Inadequate Scientific and Regulatory Oversight}

\subsubsection{No Scientifically Designed and Executed Studies}

The USGS was involved in only three of the more than 80 cycle tests conducted at 18 ASR sites in nine counties that were summarized in the USGS inventory and review (Reese, 2002). Those three cycle tests were conducted at the Lake Okeechobee/Taylor Creek/Nubbin Slough facility (20). Consulting firms involved in the construction, operation, or testing associated with the ASR cycle-test data included: Camp, Dresser, and McKee (Deerfield Beach); CH2M Hill (Lake Okeechobee, Marathon, Boynton Beach, Broward County, West Palm Beach, Miami-Dade W Well Field, City of Delray, San Carlos Estates); Post Buckley, Shuh, and Jernigan (Englewood); ViroGroup (Corkscrew, Marco Lakes); ViroGroup/Camp, Dresser, and McKee (Lee County Regional, Corkscrew); and Water Resources Solutions (N Reservoir, Marco Lakes, Olga, Corkscrew). The USGS report focused on the ASR facilities that were injecting into formations historically identified as components of the Floridan aquifer system. Of the 27 facilities, 22 (including CERP wells) injected and withdrew fluids from areas identified as the upper Floridan aquifer system, where the ground water was brackish to saline (Reese, 2002). The ASR facilities that were reviewed by USGS primarily are considered as a supplemental water supply for municipalities that have exhausted existing water resources and cannot supply potable water to their current population or have no water resources to supply potable water for future development.

The USGS (Reese, 2002) relied on data collected and provided by the utility department staff and their consultants for the majority of the cycle tests and site information included in that inventory. Those data were not collected as part of a scientifically designed and executed study. Those inadequacies limited the inferences that could be drawn from the results. Another important factor to consider is the conflict of interest associated with the data collection effort, because both the utility departments and the engineering firms that produced the data evaluated in the USGS report were positioned for considerable financial gain from government grants, contracts and other forms of funding to implement and expand ASR if results of the tests appeared favorable. Despite the inadequacies of the described ASR tests, the results of those cycle tests and related peer-reviewed scientific published literature are sufficient to conclude that ASR pilot studies are not necessary to determine that ASR injections and withdrawals in southern Florida constitute unaddressed environmental threats to the Everglades and associated surfacewater ecosystems.

\subsubsection{Monitoring}

Monitoring can be designed to evaluate water levels and water chemistry (e.g., the presence/concentration of contaminants) in wells providing access to various zones of the aquifer system. There is no indication in any records, reports, or publications available for review that monitoring wells associated with any ASR wells have been located in the surrounding natural wetlands to evaluate any potential changes in hydroperiods. Likewise, there is no indication that any comprehensive monitoring of any natural surface waters, including wetlands, has been associated with ASR wells. The primary purpose of monitoring wells required for other types of aquifer injection wells, such as those that inject sewage effluent, is to determine if the injected (disposed) fluid wastes are flowing vertically upward and may contaminate an overlying aquifer zone being used to supply water for human consumption.

Six of the ASR sites (Springtree; Shell Creek; SW Well Field; Boynton Beach East and Delray Beach North Storage Reservoir) had no monitoring wells and one lacked any information about monitoring wells in the injection ("storage") zone. Of the remaining 21 ASR sites, 15 had only a single monitoring well in the injection zone. Those sites included: Deerfield Beach W; Broward County; Fiveash; Englewood S Regional; N Reservoir; Winkler Avenue; San Carlos Estates; Hialeah; West Well Field; Marathon; Lake Okeechobee/Taylor Cr./Nubbin Slough; Jupiter; West Palm Beach; System 3 Palm Beach County; and Western Hillsboro Canal (from Reese, 
2002, Table 1). Because none of these ASR sites included monitoring wells or monitoring sites in the surrounding natural wetlands or surface waters to evaluate how the ASR injections and withdrawals altered physical, chemical and ecological conditions in natural ecosystems, no information is available regarding the impacts of those ASR injections on the transport of contaminants and hazardous substances to those waters or the impacts of those ASR injections and withdrawals on wetland hydroperiods.

Some local communities (e.g., Stuart, Florida) have established a harbor master facility with around-the-clock duty and police backup to enforce rules prohibiting sewage-related "dumping" in coastal waters (St. Johns River Water Management District, 2004). Ironically, neither the harbor master nor the police backup would have any means of detecting subsurface discharges of sewage-related contaminants that are displaced by, or contained in ASR injections and enter coastal waters as subsurface/submarine discharges. A comparable level of monitoring and enforcement for ASR and other aquifer injections does not occur, though the consequences can be just as hazardous and the technology is available.

\subsubsection{ASR Analysis and Groundwater Modeling}

Previous analysis of ASR by the ACOE, with its consultants (Mirecki, Bennett \& Lopez-Balaez, 2013), was scientifically flawed because it failed to consider preferential flow through fractures and did not even acknowledge the presence of fractures associated with that ASR site. This deficiency occurred despite the fact that two documents (ACOE, 2004c; 2014) produced by the agency of the senior author in that evaluation (Mirecki et al., 2013) identified multiple data sets of lineaments representing fractures in southern Florida, including the vicinity of the Kissimmee River. The influence of heterogeneous flow in the Floridan aquifer system influences ASR injections and withdrawals (Hutchings, Vacher, \& Budd, 2004). More specifically, none of the fractures in the vicinity of the ASR well at the single ASR site analyzed by Mirecki et al. (2013), in the vicinity of the Kissimmee River, were identified or monitored in the study, no extensive monitoring network was established in the Kissimmee River. In fact, neither this nor any of the other ASR tests evaluated in our study included isotopic analysis, trilinear chemical analysis or tracer analysis, such as those described by Bacchus et al. (2014), Davies et al. (2004), Fetter (1988), Freeze and Cherry (1979), Kincaid et al. (2004), Kincaid, Davies, Werner, and DeHan (2012), Schindel et al. (2004) and Wilcox, Solo-Gabriele and Sternberg (2004), of the ambient ground water, injected water or "recovered" water at the ASR sites. Results from those types of analyses could have been used determined if the injected fluids formed a "bubble" or flowed rapidly away from the ASR injection sites (as the chloride data suggests) and what percent, if any, of the water injected into ASR wells is "recovered."

The "monitoring" wells constructed by Mirecki et al. (2013) to test the performance of the ASR well in that study (e.g., positioned directly north and east of the ASR well) and sampling at those monitoring wells occurred only weekly, not continuously. Additionally, the chloride concentrations for injected ("recharge") water was provided in Table 2 of Mirecki et al. (2013), but the chloride concentrations of "recovered" water from those cycle tests were not included. That ASR well was constructed adjacent to the Kissimmee River Canal near the shore of Lake Okeechobee and approximately $0.5 \mathrm{~km}(\sim 1,650 \mathrm{ft})$ northeast of a fracture identified in the draft report released by ACOE (2004c). Therefore, the "monitoring" wells should not be expected to detect the preferential flow or arsenic contamination if preferential flow is occurring diagonally, in the direction of the fracture, rather than in monitoring wells (e.g., south and east of the ASR well). Preferential flow documented in the Everglades basin has been used to assess contaminant transport (Cunningham, Renken, Wacker, \& Zygnerski, 2003; Renken et al., 2004), providing additional support for assessing preferential flow in any evaluation of ASR injections and withdrawals. Based on these inadequacies of the ASR evaluation by Mirecki et al. (2013), there is no scientifically based data to support the claims of 143\%, 99\% and 102\% volume "recovered" in the three cycle tests for that study or for claims of arsenic "attenuation." Consequently, that evaluation provides no valid supporting data for the stated "overall objective of CERP ASR pilot system operations is to evaluate ASR feasibility at representative locations in south Florida," including: "(1) percent recovery of recharged surface water; (2) regulatory compliance with all state and Federal water-quality criteria; and (3) cost effective subsurface storage.” (Mirecki et al., 2013).”

The ACOE's Final TDR included a Final Technical Groundwater Model Project and ASR Report (ACOE, 2014). Although the Final TDR acknowledged the presence of fractures determined by an unidentified source, the document failed to include fractures by another source that was identified in the 2004 report (ACOE, 2004c) or the fractures and faults identified by Vernon (1951) and fractures identified by the FDOT (1973). Additionally, the ACOE's Final TDR did not identify the proximity of any of those fractures to the existing and proposed ASR wells and the ACOE's Final Technical Groundwater Model Project did not incorporate the fractures from any of those data sets (ACOE, 2014). In fact, Krause and Randolph (1989) determined more than two decades ago that 
groundwater withdrawals from the Floridan aquifer system had resulted in breaches of groundwater divides used for groundwater modeling in that regional karst aquifer system. The extent to which preferential flow through fractures contributed to the dewatering of adjacent basins was not investigated. Therefore, there is no scientific basis for not incorporating an anisotropy option in the regional model or for the first of the "Essential findings" or the 232 ASR wells recommended in the "Summery and Conclusions" of the ACOE's Final ASR Regional Study TDR, which stated:

Essential findings from this project are as follows:

- Large capacity ASR systems can be built and operated in south Florida. ...

7.6 Summary and Conclusions

The models described in this chapter were developed in support of CERP to look at regional hydrogeologic impacts of the proposed 333 ASR wells in southern Florida...

...The modeling process showed that pump pressure requirements and protection of the APPA can be met with approximately 94 ASR wells in the UFA, 37 ASR wells in the APPZ and 101 ASR wells in the $\mathrm{BZ}$ if the extraction at sites near the APPA is significantly reduced.

Figure 12A is an enlargement of the Lake Okechobee vicinity from Figure 9. This figure includes the Kissimmee CERP ASR well (1 - permitted on 5/19/04), the Taylor Creek ASR test site ( 2 - permitted on 6/22/88), the Port Myaka Experiment-1 ASR well (3 - permitted on 11/20/03), the US Sugar ASR well (4 - permitted on 1/1/90), the Moore Haven ASR well (5 - permitted on 1/15/02) and the Loer Paradise River ASR well (6 - reportedly dated 1/1/90 and unpermitted). This figure clearly shows the proximity of that Kissimmee ASR well to one of the northwest to southeast fractures identified by the ACOE (2004c, shown in green). That fracture is aligned with a sinkhole to the northwest, in Highlands County. The extension of that fracture also is aligned with a Class V and a Class I injection well to the southeast, in northeast Palm Beach County, in the vicinity of another sinkhole. Figure 12A also clearly shows the proximity of those other ASR wells associated with Lake Okeechobee to fractures identified by the ACOE (2004c, shown in red) and mapped by FDOT (1973) and the extensions of those fractures (dashed lines). Note that numerous other Class I and Class V injection wells and additional sinkholes are associated with the fractures and fracture extensions associated with those ASR wells.

\subsubsection{Performance of ASR Wells in Southern Florida Summarized by USGS}

Claims that "performance" of ASR improves after multiple cycles, or long-term injections are based solely on the ability to force larger volumes of water into the aquifer at a given well location. This phenomenon is the result of severe erosion and/or dissolution of the aquifer matrix comprising the structural component of the aquifer, meeting the USEPA's definition of fracking. More water can be forced into and extracted from the aquifer when the underground channels or conduits in the aquifer (e.g., fractures) are large, are enlarged by repeated injections and withdrawals or are connected to potential discharge points such as surface waters.

The commonly recognized concepts of karst groundwater and aquifer responses have been described in the extensive scientific literature, including documentation of preferential flow through fractures in the Floridan aquifer system since at least the 1980s (Brook, 1985) and did not require expenditure of \$45 million for ASR pilot projects that ignored those well-established facts. According to common definition, pilot projects are conducted to serve as a tentative model for future experiments or development (Soukhanov \& Ellis, 1984). The scientific literature abounds with documentation of karst aquifer responses and concomitant environmental impacts resulting from actions such as those associated with ASR. Specifically, repeated aquifer injections and withdrawals in Florida's karst aquifer system damage the structure of the aquifer system; mobilize, co-mingle with, displace and transport contaminants; result in subsurface discharges of contaminants to coastal waters; and other surface waters and destroy natural wetlands.

\subsection{Adverse Environmental Impacts}

\subsubsection{Environmental Harm from ASR Injections and Withdrawals}

The information summarized in the USGS inventory and review (Reese, 2002) provides insight regarding the lack of regulatory oversight for ASR in Florida. Clear examples are provided in the absence of any requirements for rigorous, scientifically based monitoring to determine the success of ASR injections and withdrawals and the lack of monitoring to identify adverse environmental impacts. Based on the copies of ASR permits and related documents that could be obtained after efforts spanning several years and reviewed for this evaluation, it was evident that monitoring conditions included in the original permit can be and often are abandoned after construction and initial operation of ASR wells. When the abandonment of monitoring is authorized by the regulatory agencies, it is done with the unsupported presumption that the injections and withdrawals cause no 
environmental harm. The environmental harm to Florida's coastal ecosystem from injection wells has been described in length (Bacchus, 2000a; 2001; 2002; Bacchus et al., 2014). The chemical composition of natural groundwater discharges also is essential in maintaining native plant communities characteristic of those discharges (Klijn \& Witte, 1999; Meinzer, 1927; Rosenberry, Striegl, \& Hudson, 2000). Both ASR injections and withdrawals could result in adverse impacts to the quality and quantity of groundwater seepage to native plant communities.

Additional uncertainties that could affect ecosystem restoration is the adverse environmental impacts and price of energy. The current Central and South Florida (C\&SF) Project and the proposed restoration plans require large amounts of energy to operate. The Department of Defense has in recent years considered energy to be its single largest future constraint, constituting a threat to national security (ACOE, 2014). Thus the annual energy costs of pumping water in a fully restored South Florida ecosystem could be substantial (Graham et al., 2015) and the adverse environmental impacts of that energy use were not considered by the ACOE (2014).

The regulatory agencies also require no evaluations of environmental harm from groundwater withdrawals via ASR wells or other groundwater withdrawal wells. Examples of environmental harm already evident included increasing saltwater intrusion that already is a problem in the Everglades basin (Fitterman \& Deszcz-Pan, 1999) and other areas of the Floridan aquifer system (Spechler, 1994; Spechler \& Phelps, 1997), dewatering wetlands and resulting in the spread of invasive plants (Hofstetter \& Sonenshein, 1990; Sonenshein \& Hofstetter, 1990). Groundwater withdrawals have resulted in chloride contamination of the Floridan aquifer system via fracture flow, with substantial quantities of high-chloride water leaking (migrating) vertically upward through breaches in the nearly impermeable units that confine the Upper Floridan aquifer from below, in response to pumping (Maslia \& Prowell, 1990).

Figure $12 \mathrm{~B}$ is an enlargement of the area of Figure 9 that includes the large ASR facility permitted for the City of Cocoa, Brevard County, but that facility is located in Orange County. This facility is considered the "model" for ASR in Florida, but the permits for this facility require no monitoring of environmental impacts from aquifer injections and withdrawals. Permits for the construction and operation of four ASR wells at that facility were issued in the 1980s. In 1997, permits were issued by the FDEP to construct and operate six ASR wells (UC-48-294-600 and UO-48-213-351, April 1, 1997 and June 17, 1997). The FDEP electronic database for ASR wells indicates that four additional ASR wells were tested and operated at that location in 2002 (August 1, 2002 and October 4, 2002). That cluster of ASR wells and the water treatment ponds for that facility are associated with three intersecting fractures mapped by FDOT (1973) that are located between that ASR facility and Tosohatchee State Reserve (TSR). That network of intersecting fractures also extends through the St. Johns River east of that facility. None of the permits for those ASR wells required monitoring in wetlands within state lands, such as TSR, located immediately north of the City of Cocoa's 10 ASR wells or the navigable waters of the state and US, such as the St. Johns River, for degradation of the water quality or perturbations of the natural hydroperiods of the wetlands or the river.

Figure 12C is an enlargement of the Figure 9 area and includes two ASR clusters located in DeSoto County, similar to those in Figure 12B. This ASR site is known as the Peace River ASR site, includes 22 ASR wells located along the west bank of the Peace River and is the oldest ASR project in Florida. Initial investigations began at this site in 1983, full-time operations were initiated in 1988 and the number of wells has been expanded several times since initiation (Brown, 2005). The source water for this ASR site is treated water from the Peace River, with chloride levels ranging from 30 to $162 \mathrm{mg} / \mathrm{L}$ and sulfate levels ranging from 32 to $175 \mathrm{mg} / \mathrm{L}$, respectively. In addition to periods of low flow, the Peace River also has extensive algae blooms, complicating water treatment and resulting in taste and odor problems (CH2M Hill, 1985). The ASR injection zone is located in the Suwannee zone in the upper Floridan aquifer system. The ambient groundwater quality in the Suwannee zone was reported by CH2M Hill (1985) as "slightly brackish with TDS values ranging from 650 to $800 \mathrm{mg} / \mathrm{L}$, chloride ranging from 151 to 206, sulfate ranging from 216 to $232 \mathrm{mg} / \mathrm{L}$, and low levels of metals including arsenic (7 ug/L) and calcium (75 mg/L)."

Note that the alignment of one cluster of those ASR wells is oriented in a northeast to southwest direction that coincides with the fracture mapped by FDOT (1973). That fracture appears to be centered through the long axis of that cluster of wells. A Class V injection well for reverse osmosis (RO) brine waste (pink circle) also is associated with that fracture, immediately northeast of that cluster of ASR wells. Another fracture, reported by ACOE (2004c) and oriented northwest to southeast intersects that FDOT (1973) fracture, in the center of that cluster of ASR wells and also intersects with another fracture reported by ACOE (2004c) and oriented northeast to southwest. The network of fractures and fracture intersections associated with those ASR clusters and the injection well for RO brine all intersect the Peace River immediately east of the ASR and other injection wells, 
but none of those permits required any scientifically based environmental monitoring to determine the environmental impacts of those ASR and brine waste injections and ASR withdrawals on the Peace River and associate ecosystems.

The percent "recovery" efficiency (RE) for the first cycle tests at this facility was " $321,106,115,89$, 98" based on "Volume In (Mgallons)" of "3.83, 6.38, 6.06, 6.62, 9.78” and "Volume Out (Mgallons)" of "12.29, 6.75, 6.98, 5.90, 9.58" for storage periods of 3,1,1,1 and 17 days, respectively (Brown, 2005). Clearly it is impossible to "recover" more than 3 times the volume of water that is injected into the aquifer and "stored" for only 3 days, as implied by the "Volume In" and "Volume Out" results for the first cycle test at the Peace River ASR site. Those results suggests that withdrawals from those ASR wells may be dewatering the Peace River via the network of fractures that insect the ASR wells and the Peace River.

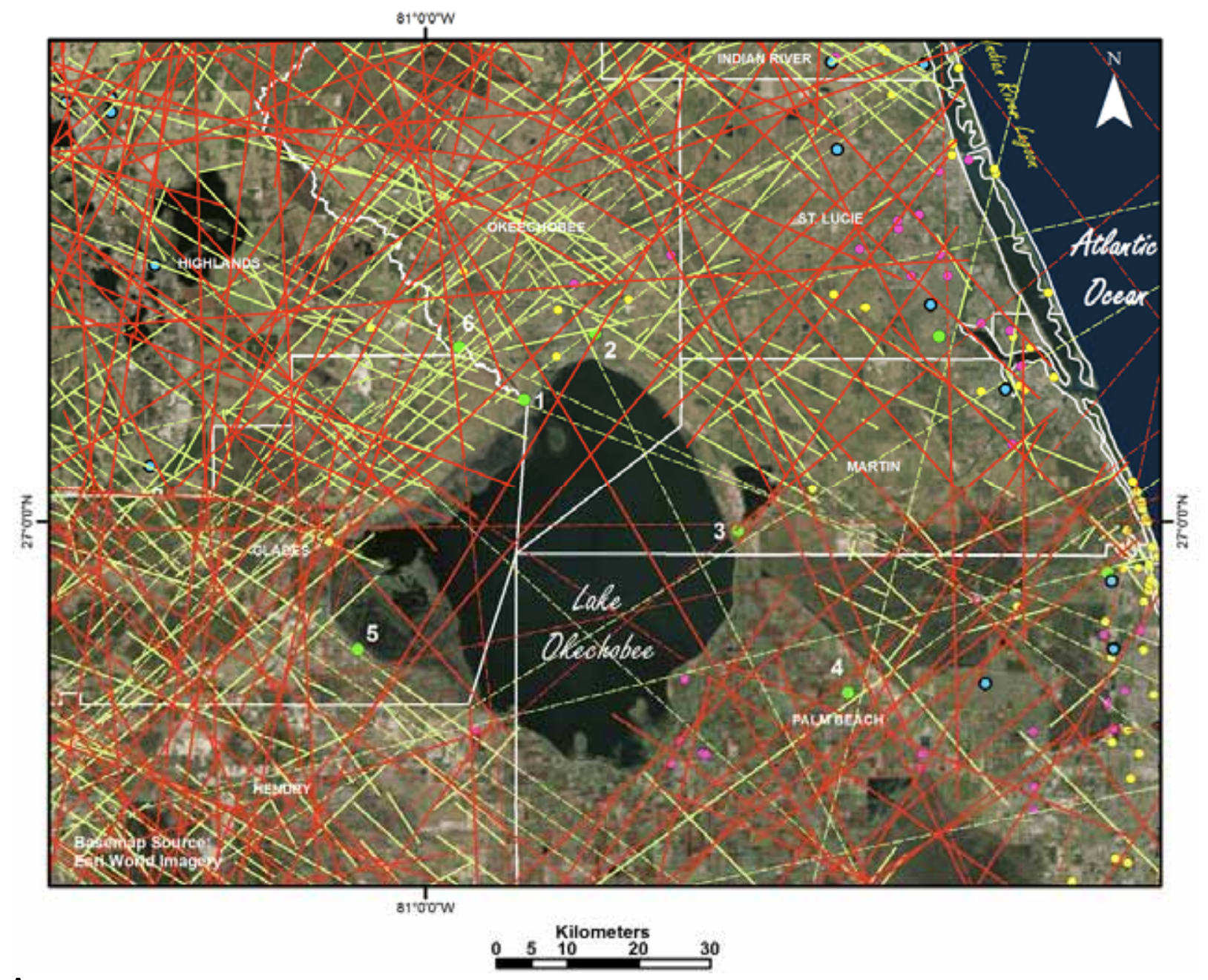

A 

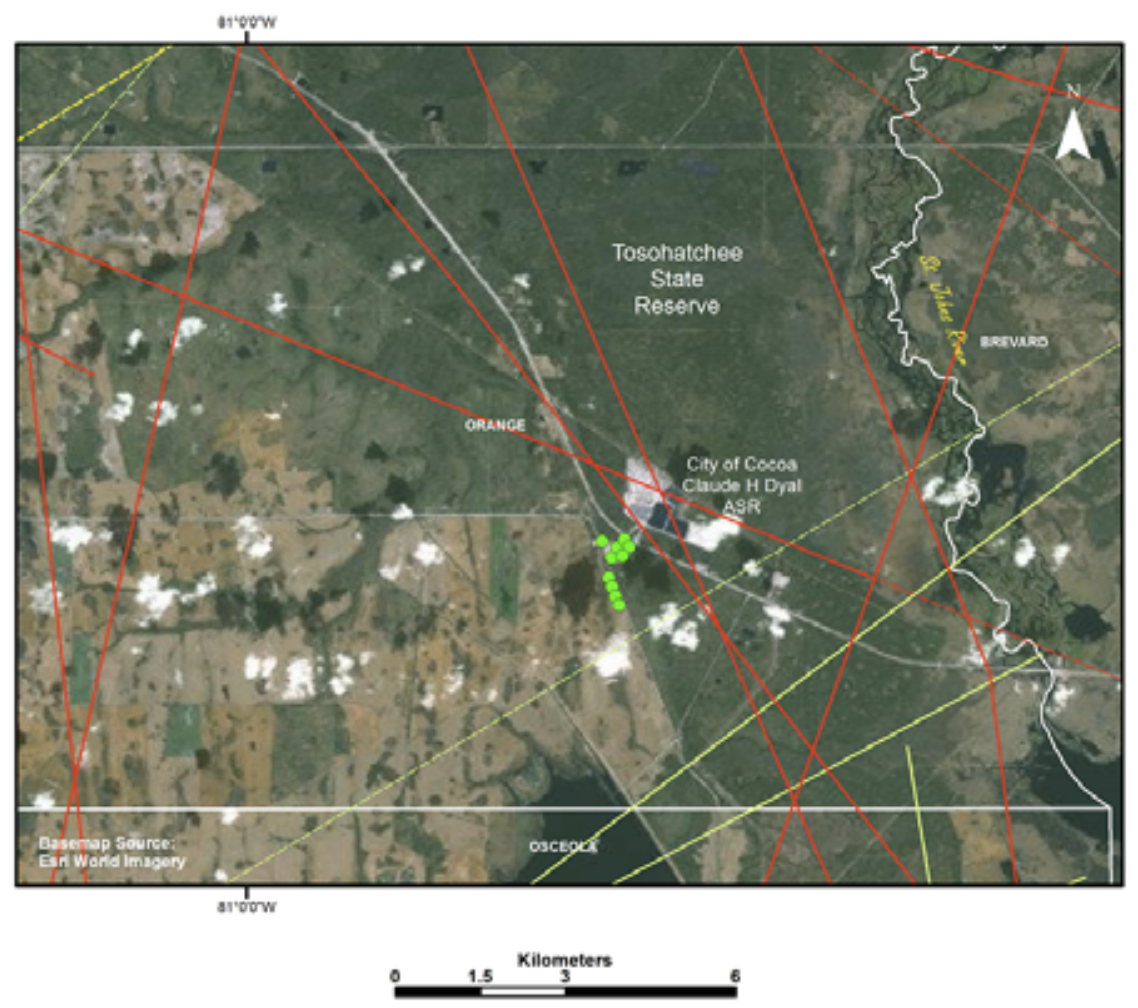

B

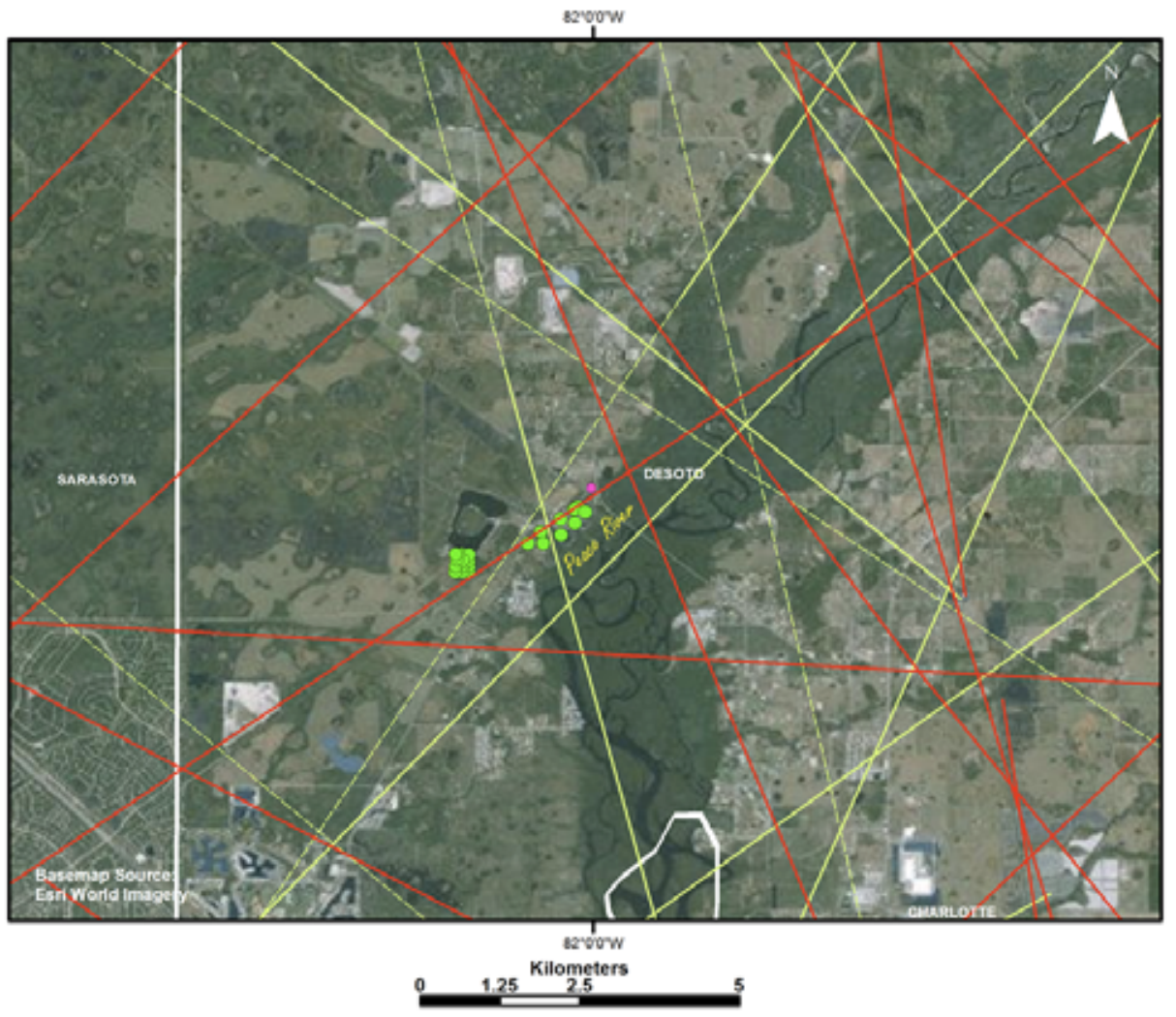

C

Figure 12. Proximity of fractures reported by ACOE (2004c) and mapped by FDOT (1973) and Vernon (1951) and extensions, as described in Figure 9, associated with permitted ASR wells (green circles), other Class V injection wells (pink circles), Class I injection wells (yellow circles), and modern sinkholes (blue circles) in the vicinity of: A. Lake Okeechobee; B. the City of Cocoa ASR facility and well cluster in Orange County; and C. the Peace River water treatment plant and ASR well cluster in DeSoto County 
Depressional pond-cypress (Taxodium ascendens) wetlands, forested riverine wetlands and upland ecosystems, all of which provide wildlife habitat, occur in the TSR and Taylor Creek, in the vicinity of the fracture network associated with those ASR wells. Some of those ecosystems exhibit typical symptoms of chronic stress from anthropogenic groundwater alterations that disrupt natural hydroperiods. Pond-cypress wetlands occur throughout the southeastern coastal plain (Godfrey, 1988), which coincides with the extent of the Floridan aquifer system (Miller, 1986). Pond-cypress wetlands occur in relict sinkholes (Stewart \& Stedje, 1990; Watson, Stedje, Barcelo, \& Stewart, 1990) and both sinkholes and streams are known to be associated with fractures in karst aquifer systems and to influence the hydrology of the Floridan aquifer system (Patten \& Klein, 1989). Therefore, wetlands in those ecosystems can be used as a hydroecological indicator of groundwater alterations that result in adverse environmental impacts (Bacchus, 1996; 1998; 2000b; Bacchus et al., 2003; Bacchus \& Brook, 1996; Bacchus et al., 2014; Bacchus, Brook \& Hamazaki, 1997; Bacchus, Hamazaki, Britton \& Haines, 2000). Bacchus et al. (2003) describe how groundwater withdrawals, including withdrawals from ASR wells, can result in hydroperiod alterations in these depressional wetlands and other ecosystems. Despite the knowledge that groundwater withdrawals can result in irreversible harm to depressional wetland ecosystems in the Floridan aquifer system, ASR wells frequently are located in the immediate vicinity of these wetland ecosystems. Another example is the ASR well at the Pelican Bay wellfield in Collier County, shown in Figure 13.

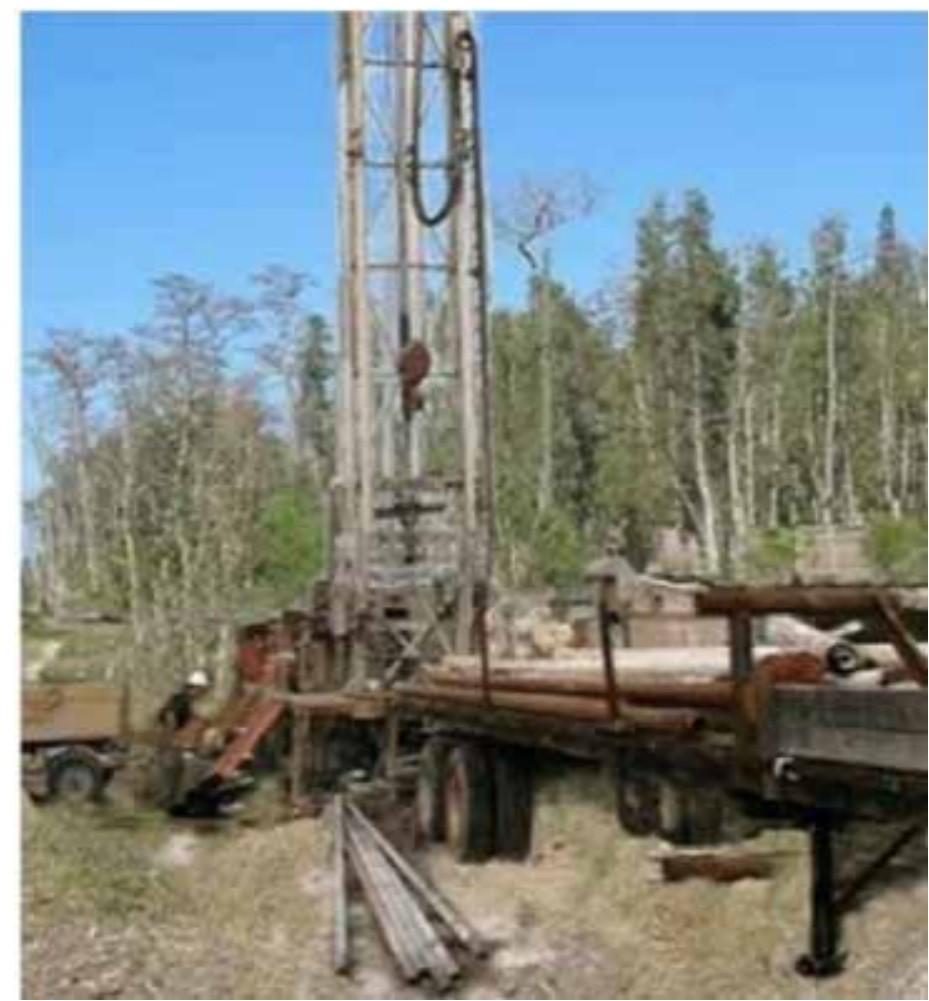

Figure 13. Drilling of ASR well at Pelican Bay wellfield in Collier County, southwest Florida, adjacent to a forested depressional pond-cypress wetland (from Water Resources Solutions, 2002 unpublished report to Collier County)

\subsubsection{Environmental Harm from Mobilization of Arsenic and Other Contaminants}

When the abandonment of monitoring is authorized by the regulatory agencies, the abandonment, like the initial permitting also presumes that the injected fluids are not harmful or hazardous to the environment without any supporting data. This approach disregards the potential mobilization of harmful contaminants present in the aquifer system (e.g., injected sewage effluent and other wastes) and mobilized from the aquifer formations (e.g., arsenic). Arsenic mobilization and contamination from ASR injections are not confined to the Greater Everglades Basin. Arsenic mobilization has been documented throughout the Floridan aquifer system (Price \& Pichler, 2004) as well as in other aquifer systems (Herczeg, Rattray, Dillon, Pavelic, \& Barry, 2004) after ASR injections of "reclaimed" water (aka sewage effluent). McNeill (2000) also documented upward migration of sewage effluent injected into the Floridan aquifer system in the Greater Everglades Basin. 
Water quality was not the focus of our study, but water quality degradation associated with operations of ASR wells in southern Florida is related to the inadequate regulation of ASR wells. In 2004, the Chief Operator of the model City of Cocoa's ASR facility was notified by letter from George Heuler in FDEP's UIC Section that "anomalous arsenic data has been accumulated at the ASR facility." The letter referenced violations of the arsenic standard (10 mg/L effective January 1, 2005) addressed in the report by Pyne, McNeal and Horvath (2004). That report identified numerous ASR wells in Florida producing water with elevated concentrations of arsenic, but did not identify those wells or facilities. The DEP letter further stated:

The Department requests that the City implement an arsenic monitoring program at the ASR facility as soon as practical in order to assess this situation using the ASR wells and any pre-existing monitoring wells at the facility. New monitoring wells may be needed in order to do this correctly. Please submit an arsenic monitoring program proposal within fourteen (14) days of receipt of this letter.

Repeated attempts through 2005 to obtain copies from FDEP of the monitoring program proposed or implemented by the City of Cocoa produced no documents. The FDEP letter referenced above also revealed that the Department's Tallahassee office had not received the "Monthly Monitoring Reports" (MORs), annual reports or general correspondence for that facility for at least 18 months.

Similarly, repeated Freedom of Information Act (FOIA) requests were submitted to the USEPA's Region 4 Headquarters in Atlanta (February 23, 2005 to September 7, 2005). Those requests were for all documents related to the City of Cocoa's ASR facility. Those FOIA requests produced only a single document, the 1992 report prepared by CH2M Hill regarding the City of Cocoa's ASR facility. No documents were produced that: (1) referenced or even acknowledged elevated arsenic levels in "recovery" water from those ASR wells or (2) addressed monitoring programs referenced in the FDEP's letter. Additionally, the arsenic standard referenced in the notice of violation letter from FDEP's UIC Section is a standard for potable water, regulated under the SDWA. That level was not established as a safe level for marine, estuarine and aquatic organisms exposed to the arsenic-laden water flowing horizontally through fractures and discharging in environmentally sensitive coastal areas or inland surface waters, because the assumption of the "UIC" program is that water injected into ASR wells is retained in a "bubble" around the end of the well. Proponents of ASR argue that arsenic-contamination of "recovery" water from ASR wells is not a concern because that water can be treated before it is distributed from municipal water supply facilities. That argument ignores the fact that preferential flow of arsenic-contaminated water can occur, contaminating private residential wells and surface waters, where the water is not treated for human consumption or ecosystem protection.

Problems related to ASR regulations based on standards for potable water are not restricted to arsenic. Nitrate pollution also represents a significant environmental threat. The SWDA allows for $10 \mathrm{mg} / \mathrm{L}$ concentrations of nitrate in water for human consumption. The maximum standard allowed in discharge of clear spring waters in the state of Florida, however, is $0.35 \mathrm{mg} / \mathrm{L}$. nitrate/nitrite. That SDWA limit is approximately two orders of magnitude greater than the limit for Florida's springs. The SDWA's allowable concentration of nitrate also is approximately three orders of magnitude greater than the natural background representative of Florida's groundwater, which is approximately $0.05 \mathrm{mg} / \mathrm{L}$. None of the water injected into ASR wells, but not recovered (i.e., 88-100\%), can be treated to remove contaminants such as arsenic and nitrate that exceed levels that are harmful to ground and surface waters before that water contaminates the aquifer and surrounding surface waters. In fact, Pyne, (1995) reported groundwater and ASR "recovery" water contamination from arsenic and upcoming (induced "recharge" from underlying brackish, saline or hypersaline groundwater) at the model Cocoa ASR site, near the Tosohatchee State Reserve. He also concluded that "karst-like conduits may exist that effectively reduce the RE percentage due to mixing and dispersion” at that ASR facility. Neither that report, nor other ASR studies evaluated if ASR injections and withdrawals resulted in contaminated ground water discharging to surface waters or other environmental impacts of those ASR injections and withdrawals.

\subsubsection{The Endangered Species Act and Migratory Bird Treaty Act}

In March, 2015, following the 2014 release of the ACOE's Final TDR addressing ASR, the University of Florida's Water Institute released an independent technical review of options to reduce the high volume of freshwater contaminated with agricultural pollutants that is being discharged to the St. Lucie and Caloosahatchee estuaries along the southeast and southwest of Florida, respectively (Graham et al., 2015). Figure III-6 of that report includes a map showing the locations of Greater Everglades Ecosystem restoration construction projects that have been completed, are under construction or are in the design or conceptual phase, but makes no specific reference to ASR wells. Despite this lack of reference to ASR, the primary focus of the ACOE's Final TDR 
promotes the large-scale incorporation of 232 ASR wells in restoration projects included in that map, such as the Kissimmee River Restoration (ACOE, 2014; Graham et al., 2015). The Water Institute's review was initiated because of the substantial adverse ecological and economic impacts from regulatory releases of fresh water from Lake Okeechobee via the St. Lucie and Caloosahatchee Rivers, but the review was based solely on pre-existing information (Graham et al., 2015).

The Water Institute's report included a discussion of the Migratory Bird Treaty Act (MBTA) that applies to adverse environmental impacts for ASR wells, although the report did include examples of those adverse environmental impacts (Graham et al., 2015). The MBTA implements four international treaties that are aimed at protecting migratory birds (16 U.S.C. $\S 703$ ). The scope of the MBTA is quite broad and covers almost all native North American birds. Some, but not all, migratory birds covered by the MBTA are also a listed species under the ESA and, thus, both Acts would apply to those species. Many of the endangered species in the Everglades are birds that also are protected by the MBTA. As with the ESA, the MBTA prohibits "takes" of covered species. Although the MBTA does not define the term "take," regulations define it to mean "pursue, hunt, shoot, wound, kill, trap, capture, or collect, or attempt” any of the foregoing (50 C.F.R. 10.12). Although not well defined, the MBTA's definition of "take" appears to be narrower than the definition under the ESA, which may include significant habitat modification or degradation where it actually kills or injures wildlife. Thus, although some general habitat changes may not be violations of the MBTA, actions such as construction of projects or flooding areas in a way that actually kill birds could be violations of the MBTA. Because of its subtropical nature and geographical location, south Florida is home to numerous endangered species dependent upon the ecological conditions that were characteristic of an un-drained south Florida landscape. At least the following four species are of primary concern in considering hydrological restoration and the routing of water within the ESA: Cape Sable Seaside Sparrow (Ammodramus maritimus sociabilis), Wood Stork (Mycteria americana), Snail Kite (Rostrhamus sociabilis) and American Crocodile (Crocodylus acutus). Examples of federally listed and state-listed species with jeopardized survival and recovery by adverse direct, indirect and cumulative impacts of aquifer injections and withdrawals in Florida are provided in Table 6A and B. Examples of cumulative impacts to be considered for compliance with NEPA are described by the United States Council on Environmental Quality (1997).

Table 6A. Examples of federally-listed species with jeopardized survival and recovery by adverse direct, indirect, and cumulative impacts of aquifer injections and withdrawals in Florida.

\begin{tabular}{|c|c|c|}
\hline $\begin{array}{l}\text { Federally-Listed } \\
\text { Species }\end{array}$ & Status & Examples of Adverse Impacts \\
\hline \multicolumn{3}{|l|}{ Mammals } \\
\hline Florida Panther & & destruction of critical wetland and upland habitat (wet prairie, \\
\hline Puma concolor coryi & Endangered & $\begin{array}{l}\text { freshwater marsh, forested wetlands); } \\
\text { potential contamination of natural water supply }\end{array}$ \\
\hline Key deer & & potential contamination of natural water supply \\
\hline Odocoileus virginianus clavium & Endangered & \\
\hline Key rice rat & & destruction of potential critical habitat \\
\hline Oryzomys palustris & Endangered & (fresh and saltwater marshes) \\
\hline Lower Keys marsh rabbit & & destruction of potential critical habitat \\
\hline Sylvilagus palustris hefneri & Endangered & (tropical hammocks) \\
\hline Florida Manatee & & harmful algal bloom (HAB)-induced mortality; \\
\hline Trichechus manatus latirostris & Endangered & $\begin{array}{l}\text { destruction/pollution of critical winter habitat } \\
\text { (warm, freshwater sites) }\end{array}$ \\
\hline \multicolumn{3}{|r|}{ (1) } \\
\hline Wood Stork & & destruction of critical nesting habitat and food base; \\
\hline Mycteria americana & Threatened & contamination of feeding areas \\
\hline \multicolumn{3}{|l|}{ Reptiles } \\
\hline Green turtle & & destruction of critical habitat \\
\hline Chelonia mydas & Endangered & $\begin{array}{l}\text { (coral reefs, seagrass beds); } \\
\text { exposure to tumor-causing compounds }\end{array}$ \\
\hline American crocodile & & destruction of critical habitat and contamination of feeding \\
\hline Crocodylus acutus & Threatened & areas in the Keys \\
\hline Eastern indigo snake & & destruction of critical habitat \\
\hline Drymarchon corais couperi & Threatened & (mangrove swamps, wet prairies, scrub) \\
\hline \multicolumn{3}{|l|}{$\begin{array}{r}\text { Plants } \\
\end{array}$} \\
\hline $\begin{array}{l}\text { Garber's spurge } \\
\text { Chamaesyce garberi }\end{array}$ & Threatened & $\begin{array}{l}\text { destruction of critical habitat } \\
\text { (pine rockland) }\end{array}$ \\
\hline
\end{tabular}


Table 6 B. Examples of state-listed species with jeopardized survival and recovery by adverse direct, indirect, and cumulative impacts of aquifer injections and withdrawals in Florida. ${ }^{1}$

\begin{tabular}{|c|c|c|}
\hline $\begin{array}{c}\text { State-Listed } \\
\text { Species }\end{array}$ & Status & Examples of Adverse Impacts \\
\hline \multicolumn{3}{|l|}{ Birds } \\
\hline $\begin{array}{l}\text { Roseate spoonbill } \\
\text { Ajaia ajai }\end{array}$ & $\begin{array}{l}\text { Special } \\
\text { Concern }\end{array}$ & $\begin{array}{l}\text { potential contamination of food source; } \\
\text { destruction of potential critical habitat } \\
\text { (mangrove-dominated pools, freshwater areas) }\end{array}$ \\
\hline $\begin{array}{l}\text { White-crowned pigeon } \\
\text { Columba leucocephala }\end{array}$ & Threatened & $\begin{array}{l}\text { destruction of potential feeding habitat } \\
\text { (tropical hardwood forests) }\end{array}$ \\
\hline $\begin{array}{l}\text { Little blue heron } \\
\text { Egretta caerulea }\end{array}$ & $\begin{array}{l}\text { Special } \\
\text { Concern }\end{array}$ & $\begin{array}{l}\text { potential contamination of food source; } \\
\text { destruction of potential critical habitat } \\
\text { (marshes, flood plains, swamps) }\end{array}$ \\
\hline $\begin{array}{l}\text { Reddish egret } \\
\text { Egretta rufescens }\end{array}$ & $\begin{array}{l}\text { Special } \\
\text { Concern }\end{array}$ & $\begin{array}{l}\text { potential contamination/elimination of food source \& } \\
\text { freshwater refugia }\end{array}$ \\
\hline $\begin{array}{l}\text { Snowy egret } \\
\text { Egretta thula }\end{array}$ & $\begin{array}{c}\text { Special } \\
\text { Concern }\end{array}$ & $\begin{array}{l}\text { potential contamination/elimination of food source \& } \\
\text { freshwater refugia }\end{array}$ \\
\hline Tricolored heron & Special & \\
\hline Egretta tricolor & Concern & potential contamination/elimination of food source \\
\hline White ibis & Special & \\
\hline Eudocimus albus & Concern & potential contamination/elimination of food source \\
\hline Brown pelican & Special & \\
\hline Pelecanus occidentalis & Concern & potential contamination/elimination of food source \\
\hline \multicolumn{3}{|l|}{ Fish } \\
\hline $\begin{array}{l}\text { Key silverside } \\
\text { Menidia conchorum }\end{array}$ & Threatened & $\begin{array}{l}\text { potential surfacewater/food source contamination from } \\
\text { induced groundwater discharge }\end{array}$ \\
\hline $\begin{array}{l}\text { Mangrove rivulus } \\
\text { Rivulus marmoratus }\end{array}$ & $\begin{array}{c}\text { Special } \\
\text { Concern }\end{array}$ & $\begin{array}{l}\text { potential surfacewater/food source contamination from } \\
\text { induced groundwater discharge }\end{array}$ \\
\hline $\begin{array}{l}\text { Key blenny } \\
\text { Starksia starksia starcki }\end{array}$ & $\begin{array}{c}\text { Special } \\
\text { Concern }\end{array}$ & $\begin{array}{l}\text { potential surfacewater/food source contamination from } \\
\text { induced groundwater discharge }\end{array}$ \\
\hline \multicolumn{3}{|l|}{ Reptiles } \\
\hline $\begin{array}{l}\text { Key ringneck snake } \\
\text { Diadophis punctatus acricus }\end{array}$ & Threatened & potential food source contamination \\
\hline $\begin{array}{l}\text { Key mud turtle, striped mud turtle } \\
\text { Kinosternom baurii }\end{array}$ & Threatened & $\begin{array}{l}\text { potential food source contamination/habitat contamination } \\
\text { from induced groundwater discharge }\end{array}$ \\
\hline $\begin{array}{l}\text { Gopher tortoise } \\
\text { Gopherus polyphemus }\end{array}$ & Threatened & $\begin{array}{l}\text { destruction of micro-climate conditions related to altered } \\
\text { hydroperiods }\end{array}$ \\
\hline $\begin{array}{l}\text { Lower Keys brown snake } \\
\text { Storeria dekayi }\end{array}$ & Threatened & potential food source contamination \\
\hline $\begin{array}{l}\text { Rim rock crowned snake } \\
\text { Tantilla oolitica }\end{array}$ & Threatened & potential food source contamination \\
\hline $\begin{array}{c}\text { Invertebrates } \\
\end{array}$ & & \\
\hline $\begin{array}{l}\text { Florida tree snail } \\
\text { Liguns fasciatus matecumbensii }\end{array}$ & $\begin{array}{c}\text { Special } \\
\text { Concern }\end{array}$ & habitat destruction related to altered hydroperiods \\
\hline
\end{tabular}

\section{Summary and Conclusions}

The initial federal-agency summary of ASR data from southern Florida (Reese, 2002) primarily was based on data collected from private industry sources that benefit financially from constructing, monitoring and maintaining ASR wells or municipal water "alternatives" required after sources of municipal water are jeopardized by “ASR” injections and withdrawals. Actual "recovery," adjusted for chloride concentrations, for more than 80 injection and withdrawal cycle tests at 18 ASR sites in 9 counties ranged from 0-12\% for "storage" periods that ranged from 0-181 days. The reported "recovery" in that study ranged from "not recorded" to 0-82\%. Despite that least conservative range, that actual "recovery" assumes that water recovered at the same chloride concentration is the same water that was injected. There is no evidence in the data to support that assumption. There was no apparent evidence that the results or "performance” of ASR were dependent on geographic area, ambient chloride concentration of the aquifer zone receiving the injections, chloride concentration of the injected fluids, injection volume, withdrawal volume, or possibly even the firm(s) responsible for construction/operation 
of the facilities.

The available evidence, including comparisons of chloride concentrations for injected and "recovered" water, confirm that ASR has not fulfilled ASR proponents' claims as a means of "storing" or "recovering" water injected into the aquifer, a "new water supply" and groundwater "recharge" alternative, or a potential solution to the eutrophication of Lake Okeechobee and the Everglades. Consequently, ASR wells simply function as additional "disposal" and water supply wells, without providing any additional aquifer capacity to support those groundwater withdrawals. Claims that "performance" of ASR improves after multiple cycles, or long-term injections are based solely on the ability to force larger volumes of water into the aquifer at a given well location. This phenomenon is the result of severe erosion and/or dissolution of the aquifer matrix comprising the structural component of the aquifer and meets the USEPA's definition of fracking. More water can be forced into and extracted from the aquifer when the underground channels or conduits in the aquifer (e.g., fractures) are: (1) large, (2) enlarged by repeated injections and withdrawals, or (3) connected to discharge points such as surface waters. Repeated aquifer injections and withdrawals in Florida's karst aquifer system damage the structure of the aquifer system; mobilize, co-mingle with, displace and transport contaminants; result in subsurface discharges of contaminants to coastal waters and other surface waters; and destroy natural wetlands.

A previous analysis of ASR by the ACOE, with its consultants (Mirecki et al., 2013), was flawed because that study: (1) failed to consider preferential flow through fractures or other karst conduits that it and others had identified; (2) did not design the monitoring locations to detect preferential flow (e.g., fracture flow) or subsurface discharges to and withdrawals from the Kissimmee River and other surface waters, including coastal waters; (3) did not include the chloride concentrations of "recovered" water from the cycle tests in that study; (4) did not include scientific analyses of the ambient receiving ground water, injected water or "recovered" water (e.g., isotopic analysis, trilinear chemical analysis or tracer analysis); (5) implied that it is possible to "recover" more water than was injected, instead of acknowledging the ASR well simply is another water supply well; and (6) suggested that "attenuation" of arsenic mobilized by aquifer-injections occurred, without addressing the probability that the arsenic-contaminated water flowed rapidly away from the site of the ASR well and monitoring wells. Consequently, that study provides no scientific support for the stated overall objective of CERP ASR pilot system operations to evaluate ASR feasibility at representative locations in south Florida, including: "(1) percent recovery of recharged surface water; (2) regulatory compliance with all state and Federal water-quality criteria; and (3) cost effective subsurface storage."

The ACOE's Final TDR included a Final Technical Groundwater Model Project and ASR Report (ACOE, 2014). That TDR relied on results from the Mirecki et al. (2013) and Reese (2002) reports and similar evaluations with the same flaws of omission. Additionally, the ACOE's Final Technical Groundwater Model Project did not incorporate the fractures from any data sets in its Groundwater Model or include any anisotropy option in that regional model for fracture flow. Therefore, there is no scientific basis for the finding in the Final TDR that "Large capacity ASR systems can be built and operated in south Florida," with 94 wells in the UFA, 37 in the APPZ and 101 the BZ, for a total of 232 ASR wells.

Finally, the Final TDR and Final Technical Groundwater Model Project did not evaluate the direct, indirect or cumulative adverse impacts of preferential flow from ASR injections and withdrawals (e.g., through fractures) on federally threatened and endangered species, environmentally sensitive areas or on the formation of new sinkholes and expansion of existing sinkholes. Preferential flow of water injected and withdrawn may be responsible for both low ASR "recovery" rates and adverse environmental impacts, such as submarine groundwater discharge (SGD) contaminated with pollutants, including nutrients that result in harmful algal blooms (HABs). The three data sets evaluated in our case study show that fractures extend throughout the entire basin and for considerable distances beyond the basin, through environmentally sensitive areas in the basin such as the Big Cypress National Preserve, Biscayne National Park, Estero Bay, Everglades National Park, Florida Keys National Marine Sanctuary, Indian River Lagoon and Marquesas Keys Wildlife Management Area. The agencies need to acknowledge that the current levels of groundwater withdrawals from the Floridan aquifer system are not sustainable, as is the case with similar karst aquifer systems in the southern US (Sharp, 1988). Instead of proceeding with additional ASR wells, the federal agencies should initiate a comprehensive Environmental Impact Statement to determine the direct, indirect and cumulative impacts on the human environment, including on federally and state-listed species, of the existing and proposed ASR wells, other aquifer injections and withdrawals and other actions that alter natural hydroperiods and propose realistic alternatives to reverse the environmental damage that already has occurred. 


\section{Acknowledgments}

The comments of three anonymous reviewers contributed significantly to our final manuscript.

\section{References}

Bacchus, S. T. (1996). Hydroecological approaches for determining and monitoring sustainable yield of groundwater resources in karst aquifers. In Proceedings of the International Conference on Water Resources and Environment Research: Towards the 21st Century, Kyoto, Japan.

Bacchus, S. T. (1998). Determining sustainable yield in the Southeastern Coastal Plain: A need for new approaches. In J. Borchers \& C. D. Elifrits (Eds.), Proceedings of the Joseph F. Poland Symposium on Land Subsidence, Belmont, CA.

Bacchus, S. T. (2000a). Predicting nearshore environmental impacts from onshore anthropogenic perturbations of ground water in the southeastern Coastal Plain, USA. In Proceedings of the 3rd International Hydrology and Water Resources Symposium of the Institution of Engineers, Perth, Australia.

Bacchus, S. T. (2000b). Uncalculated impacts of unsustainable aquifer yield including evidence of subsurface interbasin flow. Journal of the American Water Resources Association, 36(3), 457-481. http://dx.doi.org/ 10.1111/j.1752-1688.2000.tb04279.x

Bacchus, S. T. (2001). Knowledge of groundwater responses - A critical factor in saving Florida's threatened and endangered species. Part I: Marine ecological disturbances. Endangered Species Update, 18(3), 79-90.

Bacchus, S. T. (2002). The "ostrich" component of the multiple stressor model: Undermining Florida. In J. W. Porter \& K. G. Porter (Eds.), The Everglades, Florida Bay, and Coral Reefs of the Florida Keys - An Ecosystem Sourcebook (pp. 669-740): CRC Press.

Bacchus, S. T., \& Brook, G. A. (1996). Geophysical characterization of depressional wetlands: a first step for determining sustainable yield of groundwater resources in Georgia's Coastal Plain Technical Completion Report (pp. $36+$ appendices). Atlanta, GA.

Bacchus, S. T., Archibald, D. D., Brook, G. A., Britton, K. O., Haines, B. L., Rathbun, S. L., \& Madden, M. (2003). Near infrared spectroscopy of a hydroecological indicator: New tool for determining sustainable yield for Floridan aquifer system. Hydrological Processes, 17, 1785-1809. http://dx.doi.org/10.1002/hyp.1213

Bacchus, S. T., Bernardes, S., Jordan, T., \& Madden, M., (2014). Benthic macroalgal blooms as indicators of nutrient loading from aquifer-injected sewage effluent in environmentally sensitive near-shore waters associated with the south Florida Keys. Journal of Geography and Geology, 6(4), p164. http://dx.doi.org/ 10.5539/jgg.v6n4p16

Bacchus, S. T., Brook, G. A., \& Hamazaki, T. (1997). Early signs of stress in wetland vegetation as an indicator of unsustainable groundwater use in the Southeastern Coastal Plain. Technical Completion Report ERC 02-97, USDI/USGS Project 1434-HQ-96-GR02664 (pp. 50 + appendices). Atlanta, GA.

Bacchus, S. T., Hamazaki, T., Britton, K. O., \& Haines, B. L. (2000). Soluble sugar composition of pond-cypress: a potential hydroecological indicator of groundwater perturbations. Journal of the American Water Resources Association, 36(1), 55-65. http://dx.doi.org/10.1111/j.1752-1688.2000.tb04248.x

Barile, P. J. (2004). Evidence of anthropogenic nitrogen enrichment of the littoral waters of east central Florida. Journal of Coastal Research, 20(4), 1237-1245. http://dx.doi.org/10.2112/04-0212.1

Bates, R. L., \& Jackson, J. A. (1984). Dictionary of geological terms (3rd ed.). Garden City, NY: Anchor Press/Doubleday.

Beck, B. F. (1989). Engineering and Environmental Impacts of Sinkholes and Karst: Proceedings of the Third Multidisciplinary Conference on Sinkholes and the Engineering and Environmental Impacts of Karst. Brookfield, VT: A. A. Balkema Publishers.

Belt, K., \& Paxton, S. T. (2005). GIS as an aid to visualizing and mapping geology and rock properties in regions of subtle topography. GSA Bulletin, 117(1/2), 149-160. doi: 10.1130/B25463.1

Brook, G. A. (1985). Geological factors influencing well productivity in the Dougherty Plain covered karst region of Georgia. In Proceedings of the Ankara - Antalya Symposium (pp. 87-99). IAHS Publication no.161.

Brook, G. A., \& Allison, T. L. (1986). Fracture mapping and ground subsidence susceptibility modeling in 
covered karst terrain - the example of Dougherty County, Georgia. In Dougherty, P. H. (Ed.) Environmental Karst (pp. 91-108). GeoSpeleo Publications, Cincinnati, OH.

Brown, C. J. (2005). Planning decision framework for brackish water aquifer, storage and recovery (ASR) projects. (PhD Dissertation), University of Florida, Gainesville, FL.

CH2M HILL. (1985). Peace River Aquifer Storage Recovery. Report \# FC15807.H0 submitted to General Development Utilities, CH2M Hill, Gainesville, FL.

CH2M HILL. (2002). Cycle testing report for the aquifer storage and recovery facility at the City of Delray Beach's North Storage Reservoir. Technical Memorandum prepared for the City of Delray Beach Environmental Services Department.

Cunningham, K. J., Renken, R., Wacker, M., \& Zygnerski, M. (2003). Application of carbonate cycle stratigraphy to delineate porosity and preferential flow and to assess advective transport in the karst limestone of the Biscayne Aquifer. Paper presented at the Proceedings of GSA Annual Meeting and Exposition.

Davies, G. J., Kincaid, T. R., Hazlett, T. J., Loper, D., Dehan, R., \& McKinlay, C. (2004). Why do quantitative groundwater tracing? In Geoscience in a Changing World: Annual Meeting and Exposition, Denver, CO.

Dean, D. J. (2012). The Arthur H. Robinson Map Library: Robinson projection, University of Wisconsin-Madison. $\quad$ Retrieved $\quad$ September 24, 2012, from http://www.geography.wisc.edu/maplib/robinson_projection.html

Environmental Systems Research Institute-ESRI. (2015). Esri GIS Dictionary. Retrieved March 17, 2015, from http://support.esri.com/en/knowledgebase/GISDictionary/search

Fernald, E. A. \& Purdum, E. (1998). Water resources atlas of Florida. Tallahassee: Institute of Science and Public Affairs, Florida State University.

Fetter, C. W. (1988). Applied hydrogeology (2nd ed.). Columbus: Merrill Pub. Co.

Fitterman, D. V., \& Deszcz-Pan, M. (1999). Geophysical mapping of saltwater intrusion in Everglades National Park. US Geological Survey Open-File Report 99-181. Boca Raton, FL: US Geological Survey.

Florida Department of Transportation. (1973). Map of lineaments in the state of Florida. Tallahassee, FL.

Ford, D., \& Williams, P. W. (1989). Karst geomorphology and hydrology. London ; Boston: Unwin Hyman.

Freeze, R. A., \& Cherry, J. A. (1979). Groundwater. Englewood Cliffs, NJ: Prentice-Hall.

Garcia-Bengochea, J., \& Muniz, A. (1988). Aquifer Storage Recovery (ASR): A Potential Solution to the Eutrophication of Florida's Lake Okeechobee. In Proceedings of the International Symposium on Artificial Recharge of Ground Water, Anaheim, CA.

Godfrey, R. K. (1988). Trees, shrubs, and woody vines of Northern Florida and adjacent Georgia and Alabama. Athens, GA: University of Georgia Press.

Graham, W. D., Angelo, M. J., Frazer, T. K., Frederick, P. C., Havens, K. E., \& Reddy, K. R. (2015). Options to reduce high volume freshwater flows to the St. Lucie and Caloosahatchee estuaries and move more water from Lake Okeechobee to the Southern Everglades (pp. 143). Gainesville, FL: University of Florida.

Harnett, P. R. \& Barnett, M. E. (1977). Optical rose diagrams for lineament analysis. Institution of Mining and Metallurgy, Transactions, Section B: Applied Earth Science 86,102-106.

Herczeg, A. L., Rattray, K. J., Dillon, P. J., Pavelic, P., \& Barry, K. E. (2004). Geochemical processes during five years of aquifer storage recovery. Ground Water, 42(3), 438-445. http://dx.doi.org/10.1111/j.1745-6584.2004.tb02691.x

Hobbs, W. H. (1904). Lineaments of the Atlantic border region. Bulletin of the Geological Society of America, 15, 483-506.

Hofstetter, R. H., \& Sonenshein, R. S. (1990). Vegetative Changes in a Wetland in the Vicinity of a Well Field, Dade County, Florida. US Geological Survey Water-Resources Investigations Report 89-4155. US Geological Survey.

Hutchings, W. C., Vacher, H. L., \& Budd, D. A. (2004). The effects of heterogeneity of the upper Floridan aquifer on ASR systems. In Aquifer Storage Recovery IV: Science, Technology, Management and Policy Conference, Tampa, FL 
Kincaid, T. R., Davies, G. J., Hazlett, T. J., Loper, D., Dehan, R., \& McKinlay, C. (2004). Groundbreaking characterization of the karstfield Floridan aquifer in the Woodville Karst Plain of North Florida. In Geoscience in a Changing World: Annual Meeting and Exposition, Denver, CO.

Kincaid, T., Davies, G., Werner, C., \& DeHan, R. (2012). Demonstrating interconnection between a wastewater application facility and a first magnitude spring in a karstic watershed: Tracer study of the Southeast Farm Wastewater Reuse Facility, Tallahassee, Florida. Tallahassee, FL: Florida Geological Survey.

Klijn, F., \& Witte, J. P. M. (1999). Eco-hydrology: Groundwater flow and site factors in plant ecology. Hydrogeology Journal, 7(1), 65-77. http://dx.doi.org/10.1007/s100400050180

Krause, R. E., \& Randolph, R. B. (1989). Hydrology of the Floridan aquifer system in southeast Georgia and adjacent parts of Florida and South Carolina. US Geological Survey.

Lines, J. P., Bernardes, S., He, J., Zhang, S., Bacchus, S. T., Madden, M., \& Jordan, T. (2012). Preferential groundwater flow pathways and hydroperiod alterations indicated by georectified lineaments and sinkholes at proposed karst nuclear power plant and mine sites. Journal of Sustainable Development, 5(12), p78. http://dx.doi.org/10.5539/jsd.v5n12p78

Maslia, M. L., \& Prowell, D. C. (1990). Effect of faults on fluid-flow and chloride contamination in a carbonate aquifer system. Journal of Hydrology, 115(1-4), 1-49. http://dx.doi.org/10.1016/0022-1694(90)90196-5

McConnell, J. B., \& Hacke, C. M. (1993). Hydrogeology, water quality, and water-resources development potential of the Upper Floridan aquifer in the Valdosta area, south-central Georgia. US Geological Survey Water Resources Investigation Report 93-4044. US Geological Survey.

McNeill, D. (2000). A review of upward migration of effluent related to subsurface injection at Miami-Dade Water and Sewer South District Plant: Prepared for the Sierra Club - Miami Group.

Meinzer, O. E. (1927). Plants as indicators of ground water. US Geological Survey.

Merritt, M. L. (1985). Subsurface storage of freshwater in south Florida: a digital model analysis of recoverability. Alexandria, VA: US Geological Survey.

Merritt, M. L., Meyer, F. W., Sonntag, W. H., \& Fitzpatrick, D. J. (1983). Subsurface Storage of Freshwater in South Florida: A Prospectus. US Geological Survey Water Resources Investigation Report 83-4214. US Geological Survey.

Miller, J. A. (1986). Hydrogeologic Framework of the Floridan Aquifer System in Florida and in Parts of Georgia, Alabama, and South Carolina. US Geological Survey.

Mirecki, J. E., Bennett, M. W., \& Lopez-Balaez, M. C. (2013). Arsenic Control During Aquifer Storage Recovery Cycle Tests in the Floridan Aquifer. Ground Water, 51(4), 539-549. http://dx.doi.org/ 10.1111/j.1745-6584.2012.01001.x

Neuendorf, K. K. E. (2005). Glossary of geology (5th ed.). Alexandria, VA: American Geological Institute.

O’Leary, D. W., Friedman, J. D., \& Pohn, H. A. (1976). Lineament, linear, lineation - some proposed new standards for old terms. Geological Society of America Bulletin, 87(10), 1463-1469. http://dx.doi.org/10.1130/0016-7606(1976)87<1463:Lllspn>2.0.Co;2

Patten, T. H., \& Klein, J. G. (1989). Sinkhole formation and its effect on Peace River hydrology. In B. F. Beck (Ed.), Proceedings of the Third Multidisciplinary Conference on Sinkholes and the Engineering and Environmental Impacts of Karst, St. Petersburg Beach, FL.

Popenoe, P., Kohout, F., \& Manheim, F. (1984). Seismic-reflection studies of sinkholes and limestone dissolution features on the northeastern Florida shelf. Paper presented at the Proceedings of First Multidisciplinary Conference on Sinkholes, Orlando, FL

Price, R. E., \& Pichler, T. (2004). Arsenic and aquifer storage and recovery in southwest Florida: Source, abundance, and mobilization mechanism, Suwannee Limestone, upper Floridan aquifer. In Aquifer Storage Recovery IV: Science, Technology, Management and Policy Conference, Tampa, FL.

Prost, G. L. (2002). Remote Sensing for Geologists: A Guide to Image Interpretation, 2nd Ed. CRC Press, pp. 456.

Pyne, R. D. G. (1988). Aquifer storage recovery: A new water supply and ground water recharge alternative. In International Symposium on Artificial Recharge of Ground Water, Anaheim, CA.

Pyne, R. D. G. (1995). Groundwater recharge and wells : a guide to aquifer storage recovery. Boca Raton, FL: 
Lewis Publishers.

Pyne, R. D. G., McNeal, M. B., \& Horvath, L. E. (2004). Analysis of arsenic occurrence and attenuation in thirteen operational ASR wellfields in the Floridan and Hawthorn Aquifers. Florida Department of Environmental Protection.

Reese, R. S. (2002). Inventory and Review of Aquifer Storage and Recovery in Southern Florida. US Geological Survey Water Resources Investigation Report 02-4036. US Geological Survey.

Reese, R. S. (2004). Hydrogeology, water quality, and distribution and sources of salinity in the Floridan aquifer system, Martin and St. Lucie Counties Florida. Water-Resources Investigations Report 03-4242. US Geological Survey.

Reese, R. S., \& Alvarez-Zarikian, C. A. (2007). Hydrogeology and aquifer storage and recovery performance in the Upper Floridan Aquifer, Southern Florida. US Geological Survey Scientific Investigations Report 2006-5239. US Geological Survey.

Renken, R. A., Shapiro, A. M., Cunningham, K. J., Harvey, R. W., Zygnerski, M. R., Metge, D. W., Wacker, M. (2004). Pathogen transport in a sole source karst aquifer near a public well field-will everglades limestone mine expansion pose a clear and present danger to public health? In Geoscience in a Changing World: Annual Meeting and Exposition, Denver, Colorado.

Rosenberry, D. O., Striegl, R. G., \& Hudson, D. C. (2000). Plants as indicators of focused ground water discharge to a northern Minnesota lake. Ground Water, 38(2), $296-303$. http://dx.doi.org/10.1111/j.1745-6584.2000.tb00340.x

Schindel, G. M., Johnson, S., Alexander, E. C. J., Worthington, S. R. H., \& Davies, G. J. (2004). Quantitative tracing as a predictive tool to assess the potential impacts of hazardous materials to water supplies and environmental receptors. In Geoscience in a Changing World: Annual Meeting and Exposition, Denver, CO.

Sharp, J. M. J. (1998). Sustainable groundwater supplies - an evolving issue: examples from major carbonate aquifers of Texas, USA. In T. R. Weaver \& C. R. Lawrence (Eds.), Proceedings of the International Groundwater Conference, Melbourne.

Sonenshein, R. S., \& Hofstetter, R. H. (1990). Hydrologic Effects of Well-Field Operations in a Wetland, Dade County, Florida. US Geological Survey Water-Resources Investigations Report 90-4143. US Geological Survey.

Soukhanov, A. H., \& Ellis, K. (1984). Webster's II new Riverside university dictionary. Boston, MA: Riverside Publishing Company.

Spechler, R. M. (1994). Saltwater intrusion and the quality of water in the Floridan aquifer system, northeastern Florida. US Geological Survey Water-Resources Investigations Report 92-4174. US Geological Survey.

Spechler, R. M., \& Phelps, G. G. (1997). Saltwater intrusion in the Floridan aquifer system, northeastern Florida. In Georgia Water Resources Conference, Athens, GA.

St. Johns River Water Management District. (2004). Baffled - but not bemused - in Stuart. Indian River Lagoon Update, 12(4), 6.

Stewart, M. T., \& Stedje, D. (1990). Geophysical Investigation of Cypress Domes, West Central Florida. Prepared by University of South Florida Geology Department for Southwest Florida Water Management District. Brooksville, FL.

United States Army Corps of Engineers. (2004a). Central and Southern Florida Project Comprehensive Everglades Restoration Plan: Vol. 1 - Final Aquifer Storage and Recovery Pilot Project Design Report Lake Okeechobee ASR Pilot Project, Hillsboro ASR Pilot Project, Caloosahatchee (C-43) River ASR Pilot Project, 200 + Appendices.

United States Army Corps of Engineers. (2004b). Central and Southern Florida Project Comprehensive Everglades Restoration Plan: Vol. 2 - Final Environmental Impact Statement - Lake Okeechobee ASR Pilot Project, Hillsboro ASR Pilot Project, Caloosahatchee (C-43) River ASR Pilot Project, $184+$ Appendices.

United States Army Corps of Engineers. (2004c). Lineament analysis, South Florida region. Draft technical memorandum prepared by the USACE-SAJ. Jacksonville, FL: US Army Corps of Engineers.

United States Army Corps of Engineers. (2014). Central and Southern Florida Project, Comprehensive Everglades Restoration Plan, Final Technical Data Report, Aquifer Storage and Recovery Regional Study, 
October 2014. Jacksonville, FL: US Army Corps of Engineers.

United States Committee on Redefinition of Ground-Water Terms. (1988). Definitions of selected ground-water terms--revisions and conceptual refinements. Washington, DC: United States Government Printing Office.

United States Council on Environmental Quality. (1997). Considering Cumulative Effects Under The National Environmental Policy Act. US Council on Environmental Quality, Executive Office of the President.

United States Environmental Protection Agency. (2015). Hydraulic fracturing background information. Retrieved March 17, 2015, from http://water.epa.gov/type/groundwater/uic/class2/hydraulicfracturing/wells_ hydrowhat.cfm

United States Fish and Wildlife Service (2015) Endangered Species. Retrieved for verification on May 18, 2015 from http://ecos.fws.gov/tess_public/reports/species-by-current-range-county?fips=12087

United States Geological Survey. (2002). US Geological Survey Artificial Recharge Workshop Proceedings. US Geological Survey Open-File Report 2002-89. Sacramento, California: US Geological Survey Retrieved from http://water.usgs.gov/ogw/pubs/ofr0289/index.htm.

Usery, E. L., Finn, M. P., \& Mugnier, C. J. (2009). Coordinate systems and map projections, In M. Madden, (Ed-in-Chief), The Manual of Geographic Information Systems. American Society for Photogrammetry and Remote Sensing, Bethesda, Maryland, pp. 87-112.

Vernon, R. O. (1951). Geology of Citrus and Levy Counties, Florida. Florida Geological Society, Geological Bulletin, 35, 256.

Watson, J., Stedje, D., Barcelo, M., \& Stewart, M. (1990). Hydrogeologic investigation of cypress dome wetlands in well field areas north of Tampa, Florida. In Proceedings of the Focus Eastern Conference, Dublin, $\mathrm{OH}$.

Wilcox, W. M., Solo-Gabriele, H. M., \& Sternberg, L. O. R. (2004). Use of stable isotopes to quantify flows between the Everglades and urban areas in Miami-Dade County Florida. Journal of Hydrology, 293(1-4), 1-19. http://dx.doi.org/10.1016/j.jhyrol.2003.12.041

Williams, P. W. (1985). Subcutaneous hydrology and the development of doline and cockpit karst. Zeitschrift Fur Geomorphologie, 29(4), 463-482.

Wilson, A. M., \& Gorelick, S. (1996). The effects of pulsed pumping on land subsidence in the Santa Clara Valley, California. Journal of Hydrology, 174(3-4), 375-396. http://dx.doi.org/10.1016/0022-1694(95) 02722-x

\section{Copyrights}

Copyright for this article is retained by the author(s), with first publication rights granted to the journal.

This is an open-access article distributed under the terms and conditions of the Creative Commons Attribution license (http://creativecommons.org/licenses/by/3.0/). 